\title{
Comparison of Potential Radiological Consequences From a Spent-Fuel Repository and Natural Uranium Deposits
}

\author{
O. J. Wick \\ M. O. Cloninger
}

September 1980

Prepared for the

Office of Nuclear Waste Isolation

under its Contract with the

U.S. Department of Energy

under Contract DE-AC06-76RLO 1830

Pacific Northwest Laboratory

Operated for the U.S. Department of Energy

by Battelle Memorial Institute 
NOTICE

This report was prepared as an account of work sponsored by the United States Government. Neither the United States nor the Department of Energy, nor any of their employees, nor any of their contractors, subcontractors, or their empioyees, makes any warranty, express or implied, or assumes any legal liability or responsibility for the accuracy, completeness or usefuiness of any information, apparatus, product or process disclosed, or represents that its use would not infringe privately owned rights.

The views, opinions and conclusions contained in this report are those of the contractor and do not necessarily represent those of the United States Government or the United States Department of Energy.

\author{
PACIFIC NORTHWEST LABORATORY \\ operated by \\ BATTELLE \\ for the \\ UNITED STATES DEPARTMENT OF ENERGY \\ Under Contract DE-AC06-76RLO 1830
}
Printed in the United States of America Available from
National Technical Information Service
United States Department of Commerce
5285 Port Royal Road
Springfield. Virginia 22151

Price: Printed Copy $\$$

$\because$ Microfiche $\$ 3.00$

NTIS

-Pages Selling Price

001-025 $\$ 4.00$

026-050 $\$ 4.50$

051-075 $\$ 5.25$

076-100 $\$ 6.00$

$101-125 \quad \$ 6.50$

126- $150 \quad \$ 7.25$

151-175 \$8.00

176-200 $\quad \$ 9.00$

201-225 $\quad \$ 9.25$

226- $250 \quad \$ 9.50$

251-275 $\$ 10.75$

276-300 $\$ 11.00$ 


\section{2}

COMPARISON OF POTENTIAL

RADIOLOGICAL CONSEQUENCES

FROM A SPENT-FUEL REPOSITORY

AND NATURAL URANIUM DEPOSITS

0. J. Wick

M. 0. Cloninger

September 1980

Prepared for the

Office of Nuclear Waste Isolation under its Contract with the U.S. Department of Energy under Contract DE-AC06-76RLO 1830

Pacific Northwest Laboratory Richland, Washington 99352 
SUMMARY

A general criterion has been suggested for deep geologic repositories containing spent fuel--the repositories should impose no greater radiological risk than that due to naturally occurring uranium deposits. The following analys is investigates the rationale of that suggestion and determines whether current expectations of spent-fuel repository performance are consistent with such a criterion.

In this study, conducted by the Pacific Northwest Laboratory for the Office of Nuclear Waste Isolation (ONWI) under its contact with the U.S. Department of Energy, reference spent-fuel repositories were compared to natural uranium-ore deposits. Comparisons were based on 1) intrinsic characteristics, such as radionuclide inventory, depth, proximity to aquifers, and regional distribution, and 2) actual and potential radiological consequences that are now occurring from some ore deposits and that may eventually occur from repositories and other ore deposits.

The comparison results show that the repositories are quite comparable to the natural ore deposits and, in some cases, present less radiological hazard than their natural counterparts.

On the basis of the first comparison, placing spent fuel in a deep geologic repository apparently reduces the hazard from natural radioactive materials occurring in the earth's crust by locating the waste in impermeable strata without access to oxidizing conditions.

On the basis of the second comparison, a repository constructed within reasonable constraints presents no greater hazard than a large ore deposit. Even without such constraints, however, the natural hazard due to some observed radioactive releases to the biosphere in the United States far exceeds any hazard that could reasonably be expected from a spent-fuel repository.

It is recommended that if the naturally radioactive environment is to be used as a basis for a criterion regarding repositories, then this criterion should be carefully constructed. The criterion should be based on the 
radiological quality of the waters in the immediate region of a specific repository, and it should be in terms of an acceptable potential increase in the radiological content of those waters due to the existence of the repository. 
In every drop of water or breath of air there is the full potential for all life and all death and everything in between. It is good when all of the elements are in balance and somewhat worse when they are not. 



\section{CONTENTS}

SUMMARY

i i i

INTRODUCTION

CONCLUSIONS

INTRINSIC PROPERTIES COMPARISON

CHARACTERISTICS OF A NUCLEAR WASTE REPOSITORY

NATURAL RADIOACTIVE MINERAL OCCURRENCES •

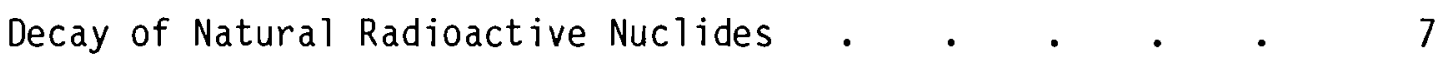

Background Levels of Radioactive Minerals $\quad$. $\quad . \quad$. $\quad$. 7

Total Uranium Occurrences in the United States . . . 13

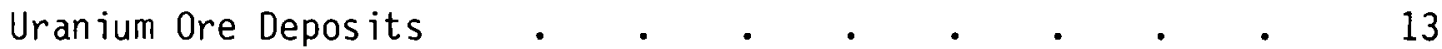

Uranium Deposits at Depth . . . . . . . . . 22

RADIOACTIVE ELEMENTS IN GROUND AND SURFACE WATERS . • • • • 22

Hydrogeology of Uranium Deposits . $\quad$. $\quad$. $\quad$. 23

Presence of Water at Depth . . . . . . . . 27

COMPARISON OF NATURAL DEPOSITS AND WASTE REPOSITORIES • • : 30

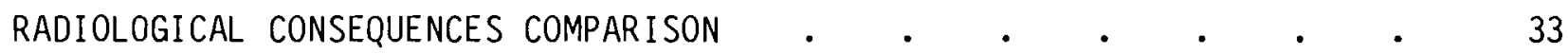

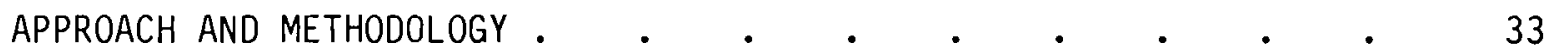

Ore Deposit Definition . . . . . . . . . . 33

Potential Consequences Analysis . . . . . . . . 35

Uranium-Radium Concentrations in U.S. Waters . . . . 37

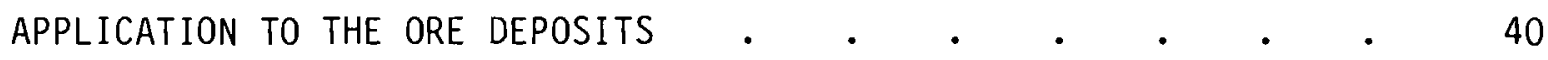

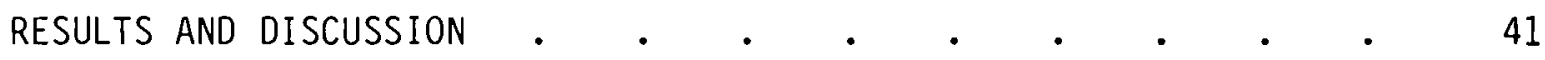

Application of the Results $\quad$. $\quad$. $\quad$. $\quad$. 42

Discussion of the Results $\quad$. $\quad . \quad \ldots \quad$. $\quad . \quad$. 51 
REFERENCES

APPENDIX

ACKNOWLEDGMENTS

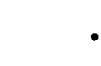

.

.

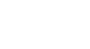

.

.

55

61

75 
FIGURES

1 Area Containing Detritus from Absaroka Volcanic Field . . $\quad$. 9

2 Distribution of Eocene Uranium Deposits in Sandstone . . . 11

3 Some Uraniferous Areas and Source Rocks in the United States . 12

4 Generalized Maximum Uranium Content of Rocks from the Phosphoria Formation and Stratigraphic Correlatives . . . . . 14

5 Comparative Uranium Inventory of Waste Repository with Inventory

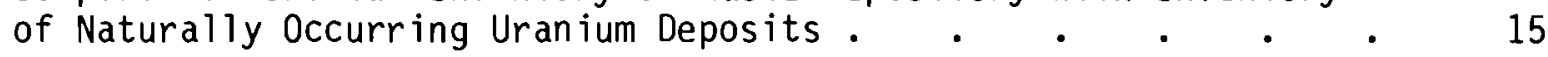

6 Significant Areas of Uranium Production in the United States . 16

7 Grants Mineral Belt Area . . . . . . . . . 17

8 Ore Distribution and Structure Contour Map of the Southeastern Ambrosia Lake Area . . . . . . . . . . 18

9 Relationship of Uranium Deposits to the Stratigraphic Units . . 19

10 Upper and Lower Altered Sandstone Tongues of the Shirley Bas in in Wyoming . . . . . . . . . . . 20

11 Significant Underground Uranium Mines .

12 Median Concentration of Uranium and Radium in Ground Water in the Geotectonic Regions of the Conterminous United States . . .

13 Solubility of Uranium Minerals at $25^{\circ} \mathrm{C}$ Under Air at

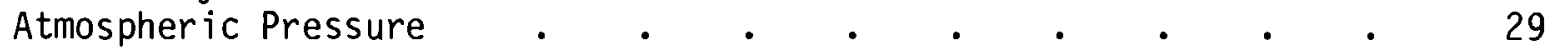

14 Formation and Migration of Uranium Deposits in Sandstone Host Rocks 30

15 Pictorial Representation of the Leach-Incident Scenario . . 38

16 Summary of Calculated Potential Radiological Consequences: Average, Annual, Total-Body Dose, General Scenario ..$\quad \cdot \quad \cdot \quad \cdot$

17 Summary of Calculated Potential Radiological Consequences: Average, Annual, Total-Body Dose, Well Scenario . . . . . .

18 Summary of Calculated Potential Radiological Consequences: Lifetime Critical-Organ Dose Commitment, General Scenario . . . .

19 Summary of Calculated Potential Radiological Consequences: Lifetime Critical-Organ Dose Commitment, Well Scenario . . . . 
A.1 Uranium-235 Decay Chain Series
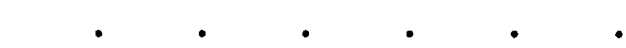

A.2 Uranium-238 Decay Chain Series

$\begin{array}{llllll}. & \cdot & \cdot & . & 6\end{array}$

A.3 Thorium-232 Decay Chain Series

- $\quad$ - $\quad$ - 


\section{TABLES}

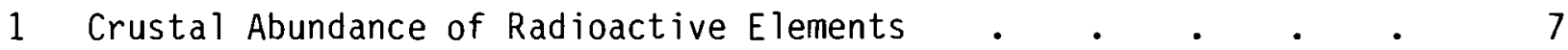

2 Distribution by Depth of Ore of 1977 U.S. Uranium Production $\quad$ - 23

3 Underground Uranium Mines in the United States $\quad . \quad$ e $\quad$ • $\quad$ e 25

4 Concentration of Uranium and Radium in U.S. Ground Water . • 26

5 Dissolved Chemical Constituents in Water from Grants Mineral Belt 28

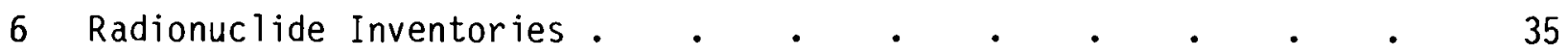

7 Reported Nuclide Concentrations in U.S. Surface and

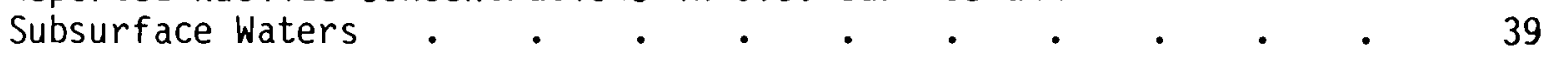

8 Uranium Deposits Sorption Coefficients, $K_{d} \quad$. $\quad$. $\quad$. $\quad$. 40

9 System Parameters for Geologic Transport Calculations . $\quad$ - 42

10 Calculated Average, Annual, Total Body Dose to Maximum Individual Due to Reported Nuclide Concentrations . . . . . . . 43

11 Lifetime Critical-Organ Dose Commitment to Maximum Individual Due to

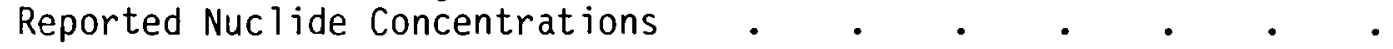

A.1 Repository Nuclide Inventories at Various Times after Closure in

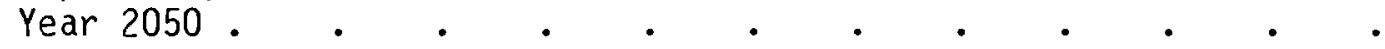

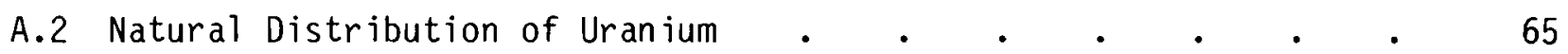

A.3 Radioactive Decay Products of Natural Uranium $\quad . \quad$. $\quad$. 66

A.4 Radioactive Decay Products of Natural Thorium . . . . . 66

A.5 Uranium and Thorium Content of Various Rock Classes . . . $\quad 70$

A.6 Volume and Uranium Content of Volcanic Rocks Remaining
in Colorado's San Juan Mountains $. . \quad . \quad . \quad . \quad . \quad 72$

A.7 Acid Intrusive Source Rocks for Uranium and Thorium . $\quad$ • . $\quad 73$ 


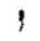




\section{INTRODUCTION}

A general criterion has been suggested for deep geologic repositories containing spent fuel--the repositories should impose no greater radiological risk than that due to naturally occurring uranium deposits. The following analysis investigates the rationale of that suggestion and determines whether current expectations of spent-fuel repository performance are consistent with such a criterion.

The analysis, conducted by the Pacific Northwest Laboratory (PNL) for the Office of Nuclear Waste Isolation (ONWI) under its contract with the U.S. Department of Energy (DOE), has two main parts. The first part compares natural ore deposits with reference geologic repositories. This comparison is based on intrinsic characteristics such as total radionuclide inventory, proximity to the earth's surface and aquifers, geographic and crustal distribution, and local average and point-specific concentration of key radionuclides. The second part compares the potential radiological consequences from reference geologic repositories with the potential and current radiological releases from natural deposits.

The earth's environment is naturally radioactive due to its original inventory of elements including uranium and its daughters. Since creation, geological processes have been transferring uranium from the earth's core to the surface by magmatic differentiation. Surface processes have further concentrated some uranium into economic deposits. The natural radioactivity varies from place to place as a result of all these processes.

The disposal of radioactive waste back to the environment, in the long term, does not change the natural inventory of uranium and its daughters, disregarding the fraction fissioned in a nuclear reactor. In the short term, the short-lived radioactive fission products add significantly to the radioactive inventory. However, uranium and its daughter radium-226 (and its daughters) are the toxic elements of major long-term concern and share this property with natural deposits. Also of long-term concern for the repository are the longlived fission products ${ }^{99} \mathrm{Tc},{ }^{14} \mathrm{C}$, and ${ }^{129} \mathrm{I}$, and the actinide ${ }^{237} \mathrm{~Np}$ and its precursor ${ }^{241} \mathrm{Am}$, which, for all practical purposes, do not exist in the natural deposits. 
Natural uranium deposits are analogous in many respects to the proposed geologic disposal of radioactive waste. Therefore the characteristics of natural deposits have been reviewed for comparison to similar characteristics of an engineered waste-disposal site.

The tools for performing a classical risk analysis on a geologic repository or a natural uranium deposit are not yet available. The bas is for the second part of the analysis was methodology developed (Burkholder et al. 1976) for estimating the potential radiologic consequences due to a scenario involving ground-water intrusion, leaching, and nuclide transport. This methodology was applied in a limited manner to predict the potential radioactive release from large uranium deposits and further to compare these predictive calculations with earlier calculations (Cloninger, Cole and Washburn 1980; Cloninger and Cole 1980) for spent-fuel repositories. The potential radiological consequences from the ore deposits were then compared to those from the repository on an equivalent basis.

The radiological consequences from measured uranium and radium concentrations from several U.S. ground and surface waters were calculated to check on the rationale of the ore deposits' release calculations and to provide actual and current data for the comparisons.

Measured uranium and radium concentrations in these waters were input to the biosphere/dose model to determine the potential consequences of using these sources. Uranium concentrations were converted to equilibrium radium concentrations to predict the potential radiological consequences. The comparison is based on potential long-term radiological consequences to man resulting from an assumed failure of a repository versus both 1) existing consequences from exposure to waters containing isotopes from natural deposits and 2) potential consequences from large, natural ore deposits.

The biological effects are expressed in terms of annual, total-body dose and lifetime, critical-organ dose to a "maximum individual" in order to be consistent with the prior analyses of the reference repositories (Cloninger, Cole and Washburn 1980; Cloninger and Cole 1980). 


\section{CONCLUSIONS}

The reference spent-fuel repositories were compared to natural uranium ore deposits 1) in terms of intrinsic characteristics, such as radionuclide inventory, depth, proximity to aquifers, and regional distribution, and 2) in terms of the calculated actual and potential radiological consequences that are occuring from some ore deposits and that may eventually occur from repositories and other ore deposits. The comparison results show that the repositories are quite comparable to the natural ore deposits and, in some cases, present less radiological hazard than their natural counterparts.

On the basis of the first comparison, placing spent fuel in a deep geologic repository apparently reduces the hazard from natural radioactive mater $i-$ als occuring in the earth's crust by locating the waste in impermeable strata without access to oxidizing conditions. Under such conditions, even in the event of containment failure, the limited solubility of material exposed to limited quantities of water permeating through geologic materials with high adsorptive capacities would restrict migration to less than the 0.1 to $1.4 \mathrm{~cm} / \mathrm{yr}$, which is the estimated migration rate for natural uranium deposits under conditions of oxygen-saturated ground water and permeable strata.

On the basis of the second comparison, a repository constructed within reasonable constraints presents no greater hazard than a large ore deposit. Even without such constraints, however, the natural hazard due to some observed radioactive releases to the biosphere in the United States far exceeds any hazard that could reasonably be expected from a spent-fuel repository.

Therefore, while at first intuition it is reasonable to use natural ore deposits as a basis for criteria for nuclear waste repositories, the variability in the natural system is so great that it does not allow a specific criterion to be stated in absolute terms.

It is suggested that if the naturally radioactive environment is to be used as a basis for a criterion regarding repositories, then this criterion should be carefully constructed. The criterion should be based on the 
radiological quality of the waters in the immediate region of a specific repository, and the criterion should be in terms of an acceptable potential increase in the radiological content of those waters due to the existence of the repository. This criterion could then be used as a basis for developing, through experimentation and modeling, specific criteria for a repository system design that is reasonably assured of meeting the environmental criteria. 


\section{INTRINSIC PROPERTIES COMPARISON}

A perspective on uranium deposits versus waste repositories requires an understanding of the quantity and distribution of naturally occurring uranium and other radioactive elements in the environment. The crustal abundance of natural radioactive nuclides is briefly presented. This is followed by a tabular presentation of the distribution of uranium in the earth's core, mantle, crust, and hydrosphere. The levels of radioactive elements in ground and surface waters are reviewed. An understanding of the processes leading to formation of uranium ore deposits is developed by reviewing 1) the source rocks that provide the uranium, 2) the host rocks in which the uranium deposits occur, and 3) a summation of the total uranium occurrences and the associated radiological activity. A more detailed description is given of economic deposits containing appreciable reserves of uranium, and data is presented on ground-water movements and uranium migration associated with these deposits. The hydrogeology of uranium deposits is discussed with information on the solubility of uranium minerals and the chemical composition of ground water from uranium-containing aquifers. A review is included of 1 ) the current depth of uranium mining in = the United States and 2) the relation of depth to the permeability of host rocks and to the presence of water, which is necessary for the transport of uranium.

Finally, radioactive decay charts are included (see the Appendix) because of the radiological importance of daughter products. Also included in the Appendix tables are factors for the conversion from curies to grams of the various elements. This conversion is important since radiological effects are considered in terms of curies while physical resources are based in mass units of grams or tons.

\section{CHARACTERISTICS OF A NUCLEAR WASTE REPOSITORY}

A proposed repository for spent-fuel elements from pressurized water reactors (PWR) is compared with natural uranium occurrences. The inventory of radioactive nuclides contained in the repository at various times after closure is shown in Appendix Table A.1 (U.S. Department of Energy 1979). Repository 
characteristics and the assumed conditions controlling the release of radioactive elements to the environment in the event of containment-system failure are given in the following list.

Inventory of radionuclides per repository $24,000 \mathrm{Ci}^{238} \mathrm{U}$ 72,000 tonne ${ }^{238} \mathrm{U}$

Equivalent number of spent PWR fuel elements 156,000 Number of spent PWR fuel elements per acre 92

Area of repository 1690 acre $\left(2.64 \mathrm{mi}^{2}\right)$

Area per fuel element

0.01 acre

Depth of repository below surface $600 \mathrm{~m}(1969 \mathrm{ft})$

Inventory of ${ }^{238} \mathrm{U}$ per fuel element

0.462 tonne

Inventory of ${ }^{238} \mathrm{U}$ per acre

42.5 tonne

Thickness of zone occupied by fuel elements Integrated ${ }^{238} \mathrm{U}$ density $3.8 \mathrm{~m}(12.47 \mathrm{ft})$

Containment-system failure

$0.16 \%$

Ground-water velocity

1.0 to $10^{6} \mathrm{yr}$

Migration path length

$1.5 \times 10^{-2}$ to $11.0 \mathrm{~m} / \mathrm{yr}$

Ground-water travel time

0.2 to $64 \mathrm{~km}$

Release rate

15 to $10^{6} \mathrm{yr}$

1.0 to $10^{-6} \% / y r$

NATURAL RADIOACTIVE MINERAL OCCURRENCES

The principal, natural radioactive nuclides found in the earth's crust are uranium-238, uranium-235, thorium-232, potassium-40, and rubidium-87. Radioactive decay of these nuclides results in radioactive daughter products such as radium-226 and radon-222. Other natural radioactive nuclides result from cosmic-ray bombardment of stable nitrogen-14, oxygen-16, and argon-40, producing tritium, $\left({ }^{3} \mathrm{H}\right)$ and carbon-14 among others. The crustal abundance of radioactive elements is shown in Table 1 (Brobst and Pratt 1973; Rohrmann 1969; Weast 1974).

The natural distribution of uranium in the earth's core, mantle, and crust, as well as uranium distribution between the continental and oceanic crust and in the hydrosphere is shown in Appendix Table A.2 (Deffeyes and Macgregor 1978). 
TABLE 1. Crustal Abundance of Radioactive Elements

\begin{tabular}{|c|c|c|c|c|c|c|}
\hline Element & $\begin{array}{c}\text { Abundance, } \\
\mathrm{ppm}\end{array}$ & $\begin{array}{l}\text { Radioactive } \\
\text { Isotope }\end{array}$ & $\begin{array}{c}\text { Percent } \\
\text { of } \\
\text { Natural } \\
\text { Abundance } \\
\end{array}$ & $\begin{array}{c}\text { Hallf-life, } \\
\quad y r \\
\end{array}$ & Decay & $\begin{array}{c}\text { Abundance } \\
\text { of } \\
\text { Isotope, } \\
\text { ppb }\end{array}$ \\
\hline \multirow[t]{2}{*}{ Uranium } & 1.7 & Uran ium-235 & 0.72 & $7.1 \times 10^{8}$ & $\alpha$ & 12 \\
\hline & & Uran ium-238 & 99.27 & $4.51 \times 10^{9}$ & $\alpha$ & 1,700 \\
\hline Thorium & 5.8 & Thor ium-232 & 100 & $1.39 \times 10^{10}$ & $\alpha$ & 5,800 \\
\hline Potassium & 25,900 & Potass ium-40 & 0.00118 & $1.28 \times 10^{9}$ & $\beta$ & 306 \\
\hline Rubidium & 310 & Rub idium-87 & 27.85 & $5 \times 10^{11}$ & $\beta$ & 86,000 \\
\hline
\end{tabular}

Decay of Natural Radioactive Nuclides

All radioactive elements spontaneously decay to stable elements in a series of stages. Once equilibrium is established the radioactivity associated with every stage is equal. Thus the decay chain of uranium-238 consists of 14 stages and the total radioactivity at equilibrium is 14 times that associated with uranium-238 decay to thorium-234. The decay chains of uranium-235, uranium-238, and thorium-232 are shown respectively in Figures A.1, A.2, and A.3, in the Appendix. The radioactive decay products of natural uranium are listed in Table A.3 (Benedict and Pigford 1957), and the radioactive decay products of thorium are listed in Table A.4 (Benedict and Pigford 1957).

Background Levels of Radioactive Minerals

The concentration of radioactive elements in the earth's crust is subject to wide variation depending upon the rock type, basic rock chemistry, and the rock's geographic location. According to a survey of over 2000 analyses of rocks from around the world, by $\mathrm{H}$. A. Wollenberg of Lawrence Berkley Laboratory, University of California, the concentration of uranium in rocks ranges from $30 \mathrm{ppb}$ to $720 \mathrm{ppm}$ and of thorium from 0 to $880 \mathrm{ppm}$. The range and mean 
value of uranium and thorium content for different rock classes is shown in Table A.5 (according to A. A. Wollenberg).

\section{Source Rocks}

Uranium content of the whole earth is estimated to be $10.5 \mathrm{ppb}$. However, most of this uranium has been concentrated in the mantle and crust by geological processes. Igneous processes (melting) have further transported uranium from the mantle to the crust and have deposited it in veins or have distributed it in intrusive and extrusive rocks. Sedimentary processes have further distributed uranium by erosion, leaching, and precipitation. Under favorable conditions uranium was concentrated in stream beds before the earth's atmosphere became oxidizing ( 1.8 billion years before present) creating the fossil placers of the Witwatersrand in South Africa and Elliott Lake in Canada. Under later oxidizing conditions, uranium was leached by surface and ground waters and transported eventually to the ocean; in the process uranium was precipitated where reducing conditions were encountered. Most U.S. uranium deposits originated from this process.

Effusive Rocks (Volcanic tuffs, breccias). Volcanic tuffs and breccias are important sources of uranium found in the environment and in many commercial sandstone deposits and uraniferous lignites. These acidic rocks containing from 5 to $300 \mathrm{ppm}$ uranium have been ejected into the atmosphere from volcanos and deposited in thin layers over thousands of square miles. The uranium in these permeable fragmented rocks is leached by surface and ground water and transported ultimately to the sea except where reducing conditions are encountered and uranium is deposited. An example of a volcanic source rock is the tuff from the Absaroka volcanic field in Wyoming. The volcanic field covered 40,000 $\mathrm{mi}^{2}$ of Wyoming, Montana, North Dakota and South Dakota and contained $\sim 5 \mathrm{ppm}$ uranium or $\sim 20 \times 10^{6}$ tons uranium (Denson and Gill 1965). Water draining these rocks contains $20 \mathrm{ppb}$ or more uranium. The average uranium content of 12 samples of spring and well water from tuff beds was $33 \mathrm{ppb}$. The average of 6 samples of spring and well water near known uranium occurrences was $153 \mathrm{ppb}$ while 5 samples from nontuffaceous rocks averaged 3 ppb uranium. The area covered is indicated in Figure 1. 


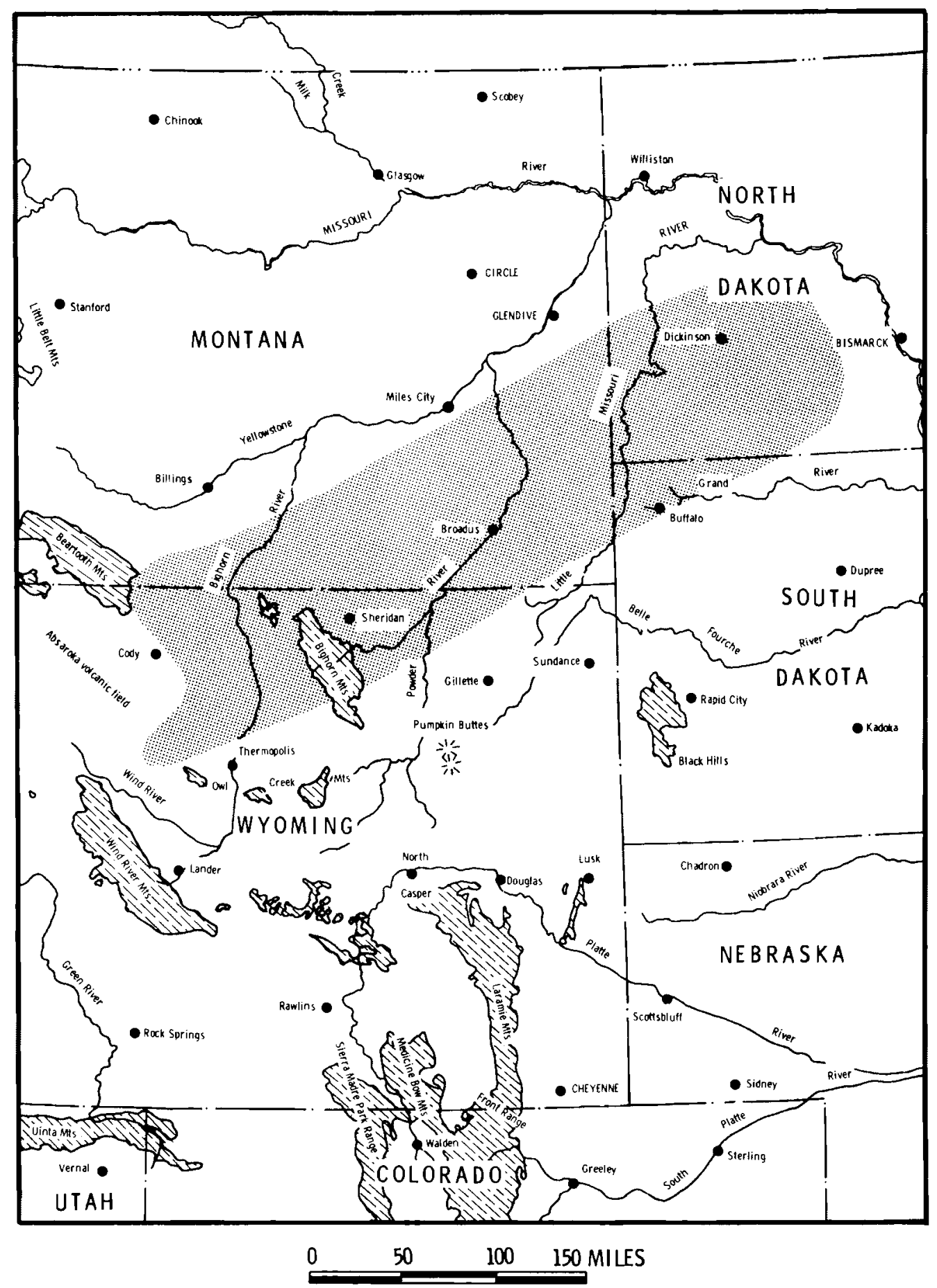

FIGURE 1. Area Containing Detritus from Absaroka Volcanic Field 
The volcanic rocks of the San Juan Mountains in Colorado cover an area of about $8000 \mathrm{mi}^{2}$ and contain from 1.3 to $5.5 \mathrm{ppm}$ uranium or $\sim 1.26 \times 10^{8}$ tons uranium as itemized in Table A.6 (Larsen et al. 1958).

Intrusive Rocks (granites, etc.). Granitic rocks exposed over large areas and containing from 5 to $30 \mathrm{ppm}$ uranium are credited as the source of many uranium deposits near the rock outcrops. Some of the granitic rocks are regarded as ultimate resources of uranium and thorium that could be exploited at tolerable costs. Some of these occurrences are listed in Table A.7 (Waldepoh1 1969, p. 92-I-1).

\section{Host Rocks}

The original source of most of the uranium in the earth's crust is magmas and igneous rocks (Finch 1967). Ground water leaches uranium from these sources and transports it via permeable rocks where it may encounter reducing conditions and be precipitated. Otherwise uranium remains in solution and moves ultimately to the oceans. Sandstones, because of their permeability, are favorable channels for ground water circulation and become host rocks for uranium deposition where they contain carbonaceous matter, sulfides, or other reducing materials. Uranium in the oceans is precipitated in organic muds or phosphate sediments-examples of these are the black shales, Chattanooga shale, Phosphoria formation, and the Florida phosphate beds.

Sandstones. Approximately 4600 uranium deposits in sandstone are known in the United States. Most occur in the west central states of New Mexico, Colorado, and Wyoming and are the major source of U.S. mined uranium and uranium reserves. Sandstone host rocks outcrop or underlie huge areas of the West as indicated by the outlines of sedimentary basins in Figure 2 (Finch 1967, p. 68).

Shales. Marine shales are exposed or underlie large areas in the central and eastern United States. Many contain more than average uranium content and are potential economic deposits (see Figure 3) (Cathcard 1956; Mapel 1956; McKelvey and Carswell 1956; Swanson 1956). The Chatanooga shale and correlatives occupy an area of $800,000 \mathrm{mi}^{2}$ in Tennessee, Kentucky, Alabama, Georgia, Ohio, and Indiana and extend to Texas and Montana. The beds average $40 \mathrm{ft}$ 


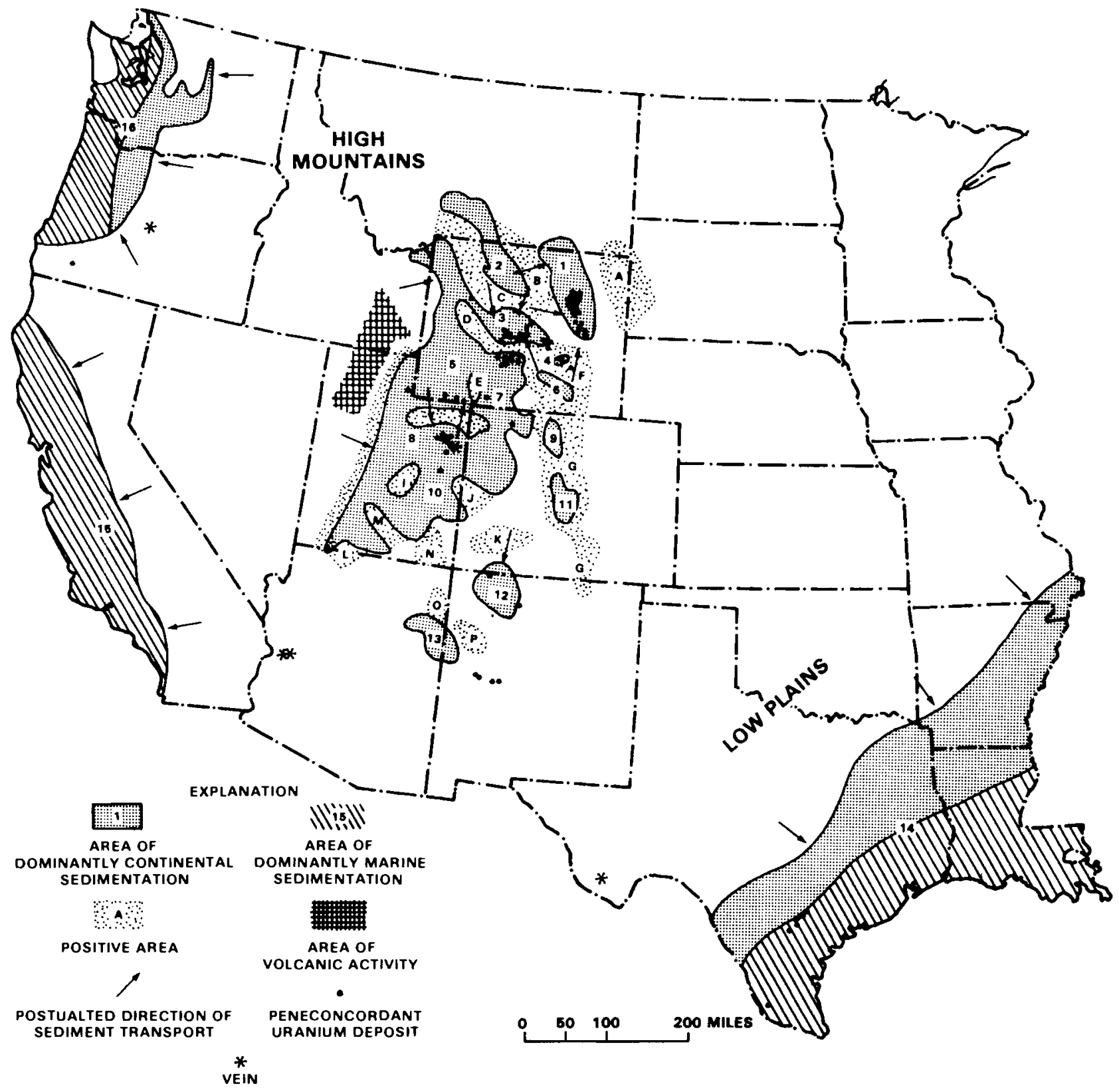

FIGURE 2. Distribution of Eocene Uranium Deposits in Sandstone

thick, contain $30 \mathrm{ppm}$ uranium, and contain $1.9 \times 10^{9}$ tons uranium. The Gassaway member of the Chatanooga shale contains twice the average amount of uranium or about $60 \mathrm{ppm}$, is 12 to $18 \mathrm{ft}$ thick, and contains $5.7 \times 10^{6}$ tons uranium. The Gassaway member also contains $8.7 \mathrm{ppm}$ thorium, which is equivalent to $8.4 \times 10^{5}$ tons thorium. 


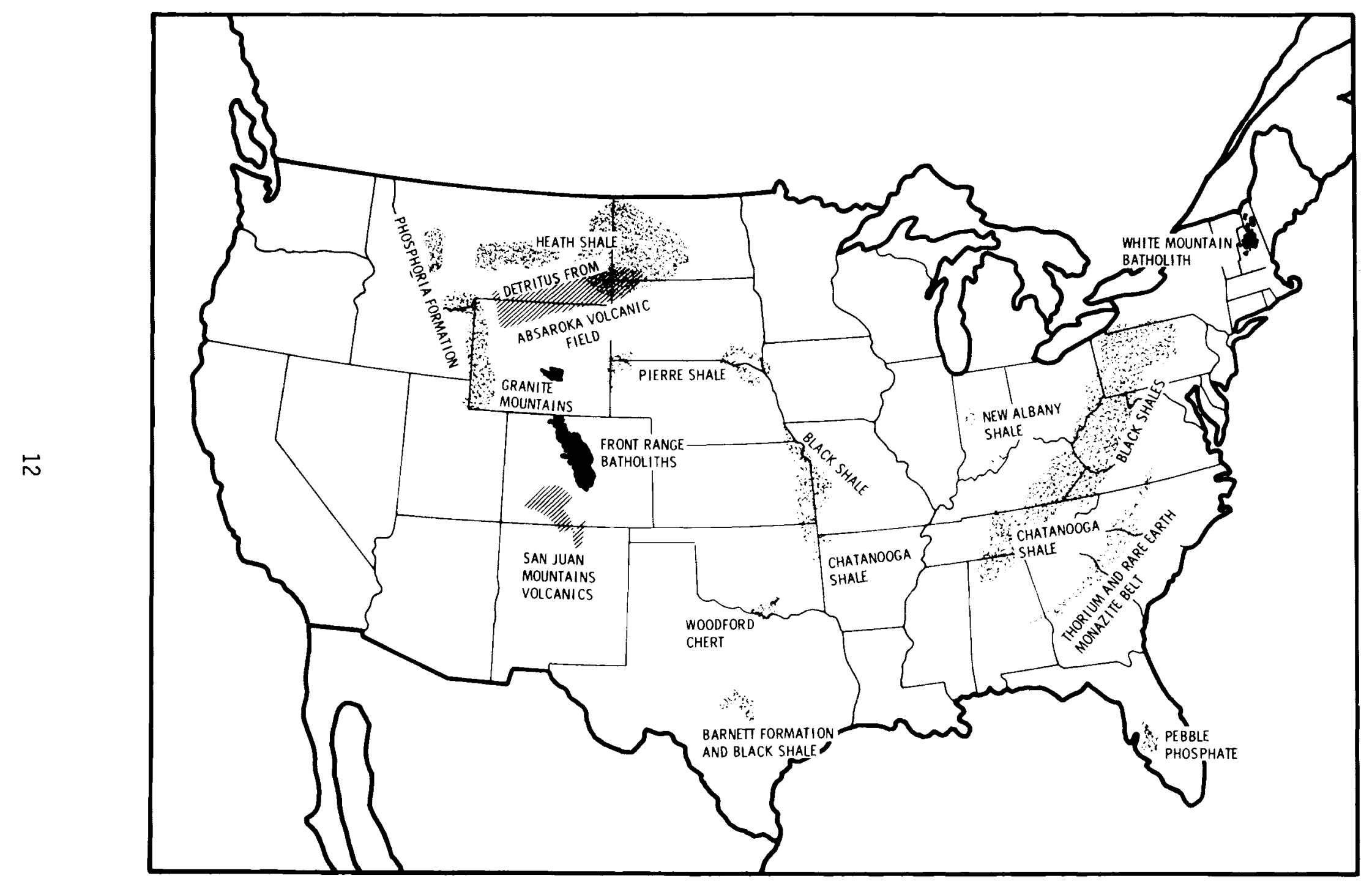

FIGURE 3. Some Uraniferous Areas and Source Rocks in the United States 
The marine Phosphoria formation underlies or outcrops in $135,000 \mathrm{mi}^{2}$ of Idaho, Wyoming, and Montana (see Figures 3 and 4) (McKelvey and Carswell 1956). It contains $100 \mathrm{ppm}$ uranium, which is equivalent to 600,000 tons uranium.

The Land Pebble Phosphate District in Florida covers $1000 \mathrm{mi}^{2}$ with uranium concentrations of $150 \mathrm{ppm}$ in some areas (see Figure 3). The Bone Valley formation in the district covers several hundred square miles and contains $100 \mathrm{ppm}$ uranium, which is equivalent to 254,000 tons uranium.

\section{Total Uranium Occurrences in the United States}

The total uranium inventory of the earth is estimated as $6.3 \times 10^{13}$ tonne (Deffeyes and Macgregor 1978) or $2 \times 10^{13} \mathrm{Ci}$. This is equivalent to the uranium inventory in 877 million standard repositories. The uranium inventory of the United States is estimated as $2.4 \times 10^{12}$ tonne (Deffeyes and Macgregor 1978) or $8 \times 10^{11} \mathrm{Ci}$ and is equivalent to the uranium in 34 million repositories. If currently mineable-grade uranium is $300 \mathrm{ppm}$ or greater, the cumulative amount of uranium in the United States is 19 million tonne (Deffeyes and Macgregor 1978) or $6.3 \mathrm{million} \mathrm{C} i$ and is equivalent to the uranium in 264 repositories. January 1, 1978 DOE estimates of potential uranium resources available at $\$ 50$ per pound of $\mathrm{U}_{3} \mathrm{O}_{8}$ is $2.7 \mathrm{million}$ tonne uranium (U.S. Department of Energy 1978) or 0.9 million $\mathrm{Ci}$, which is equivalent to the uranium content of 37 repositories.

Thus the inventories of natural uranium are orders of magnitude greater than the inventories that are contemplated for spent-fuel repositories. This information is summarized in Figure 5 .

Uranium Ore Deposits

The principal uranium ore deposits in the United States occur in the western states as shown in Figure 6 (U.S. Department of Energy 1978). The largest uranium ore deposits are in New Mexico, Colorado, Utah, and Wyoming. A detailed description of some of the large deposits follows.

\section{Grants Mineral Belt}

The Grants Mineral Belt is a series of related uranium deposits occurring in a band extending some $100 \mathrm{mi}$ across northwestern New Mexico as outlined in 


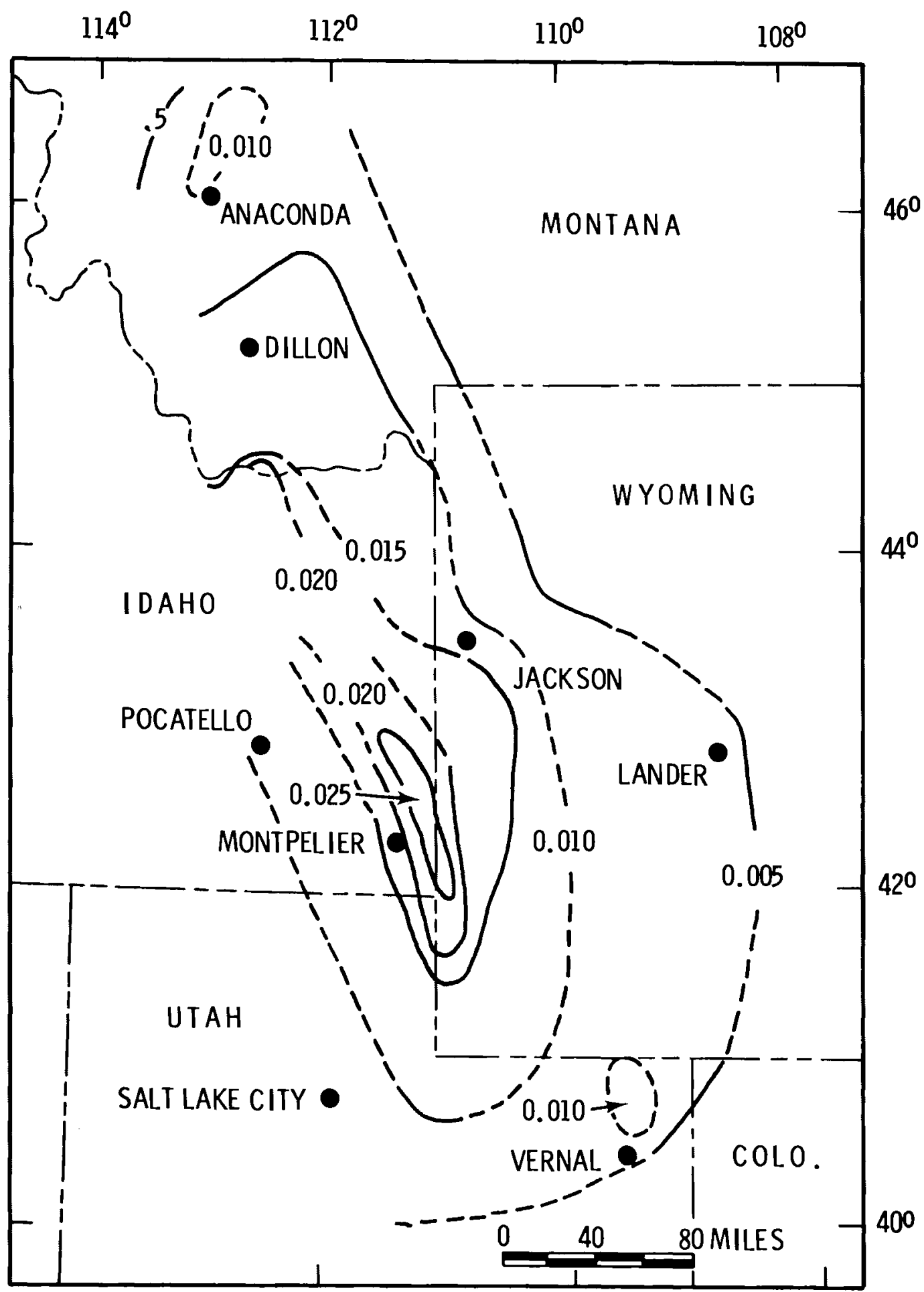

FIGURE 4. Generalized Maximum Uranium Content (percent) of Rocks from the Phosphoria Formation and Stratigraphic Correlatives 
TOTAL URANIUM, METRIC TONS

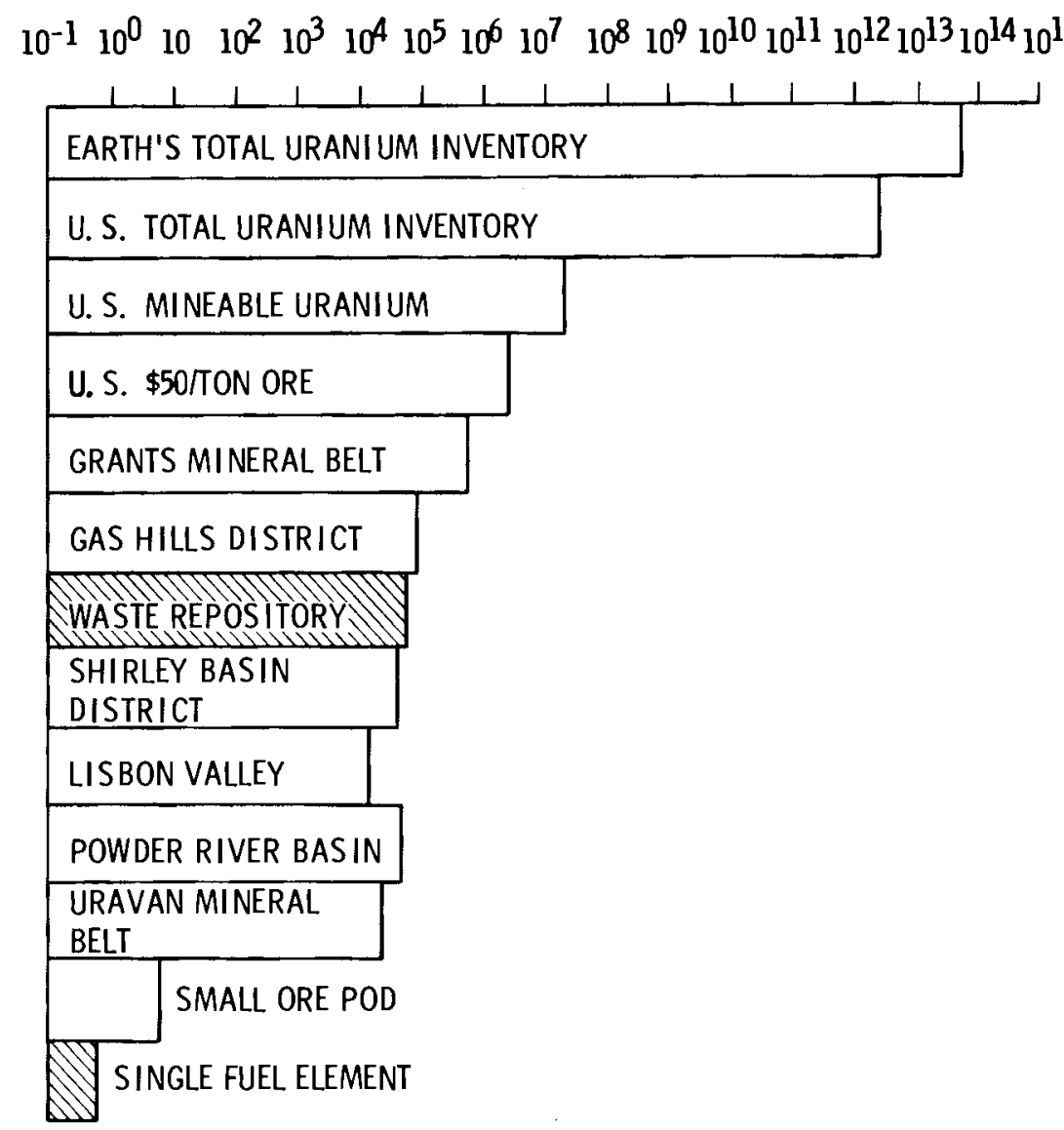

FIGURE 5. Comparative Uranium Inventory of Waste Repository with Inventory of Naturally Occurring Uranium Deposits

Figure 7 (Barnes, Geller and Hill 1977; Hilpert 1969). The belt has a cumulative production plus $\$ 50$ reserves of 684,000 tonne of uranium (Arnold and Hill 1980) equivalent to $228,000 \mathrm{Ci}$. The uranium occurs in sandstones and 1 imestones that served as channels for uranium-bearing ground water. Uranium deposited where reducing conditions were encountered, generally in a series of lens-like concentrations. Figure 8 is an example of the areal distribution of ore while Figure 9 illustrates the distribution in cross section (Kelley 1963). Uranium occurs near the surface where it is mined by open pit methods. It also occurs at depths as much as $1500 \mathrm{ft}$ where it is mined by underground methods. 


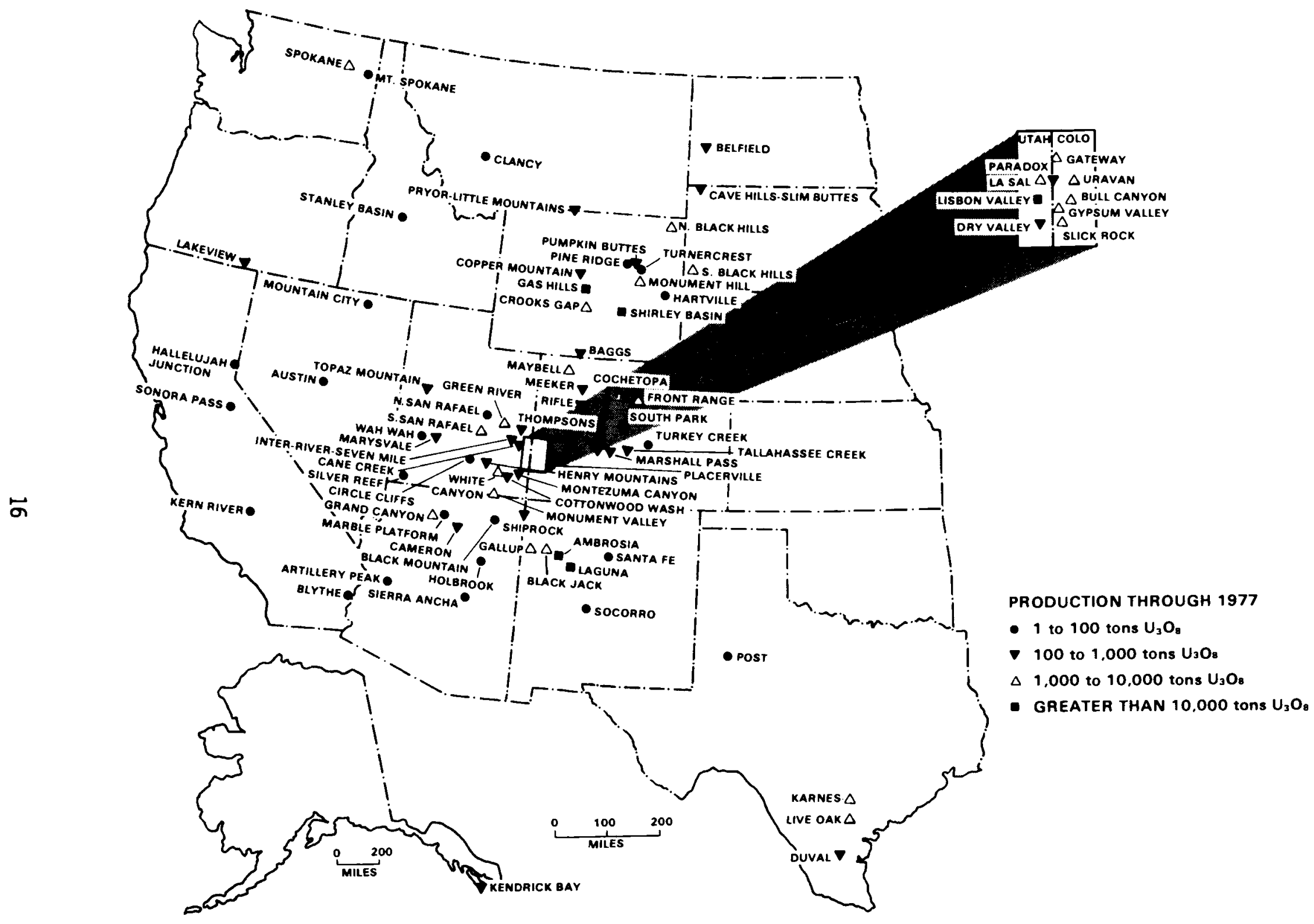

FIGURE 6. Significant Areas of Uranium Production in the United States 


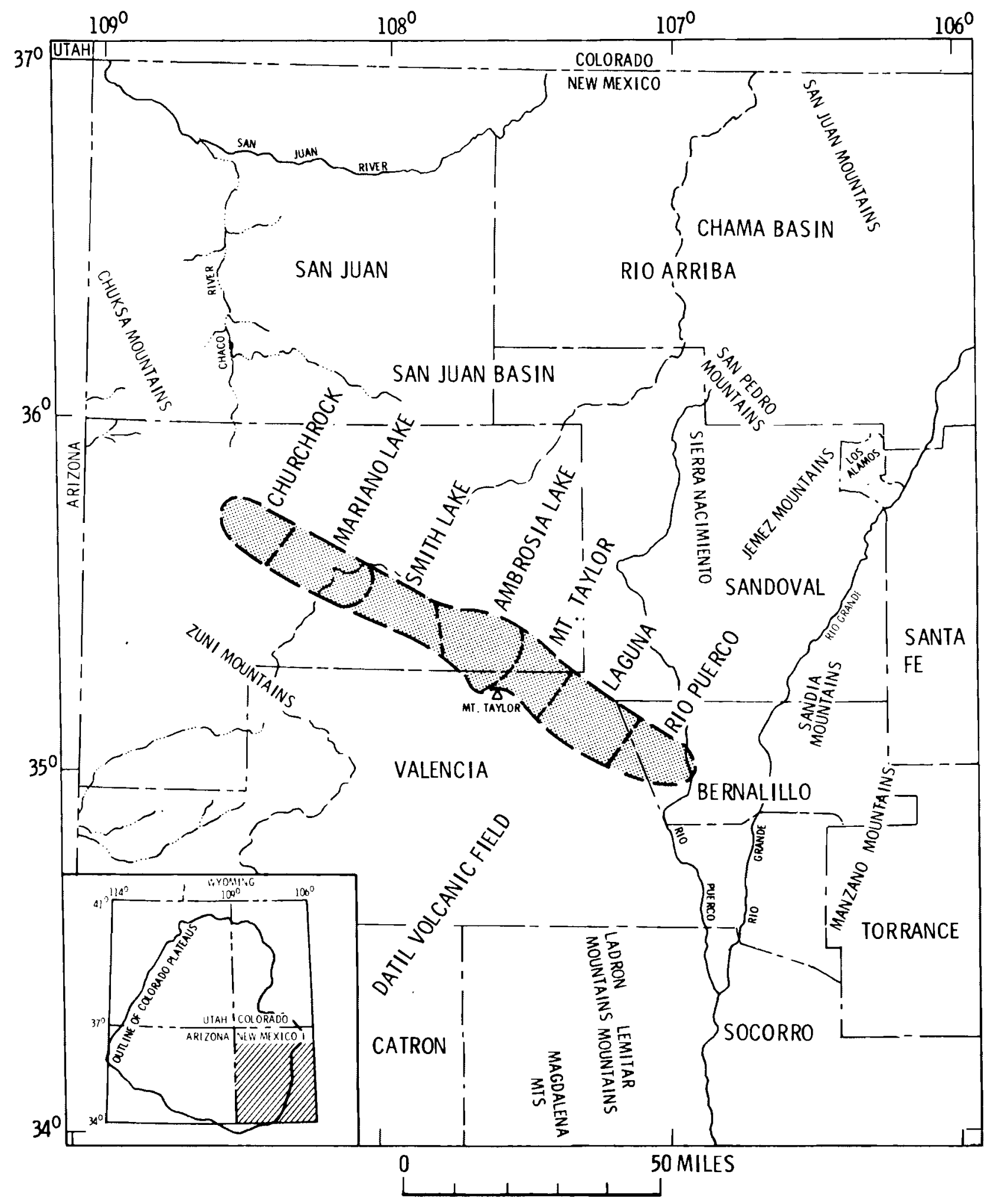

FIGURE 7. Grants Mineral Belt Area 


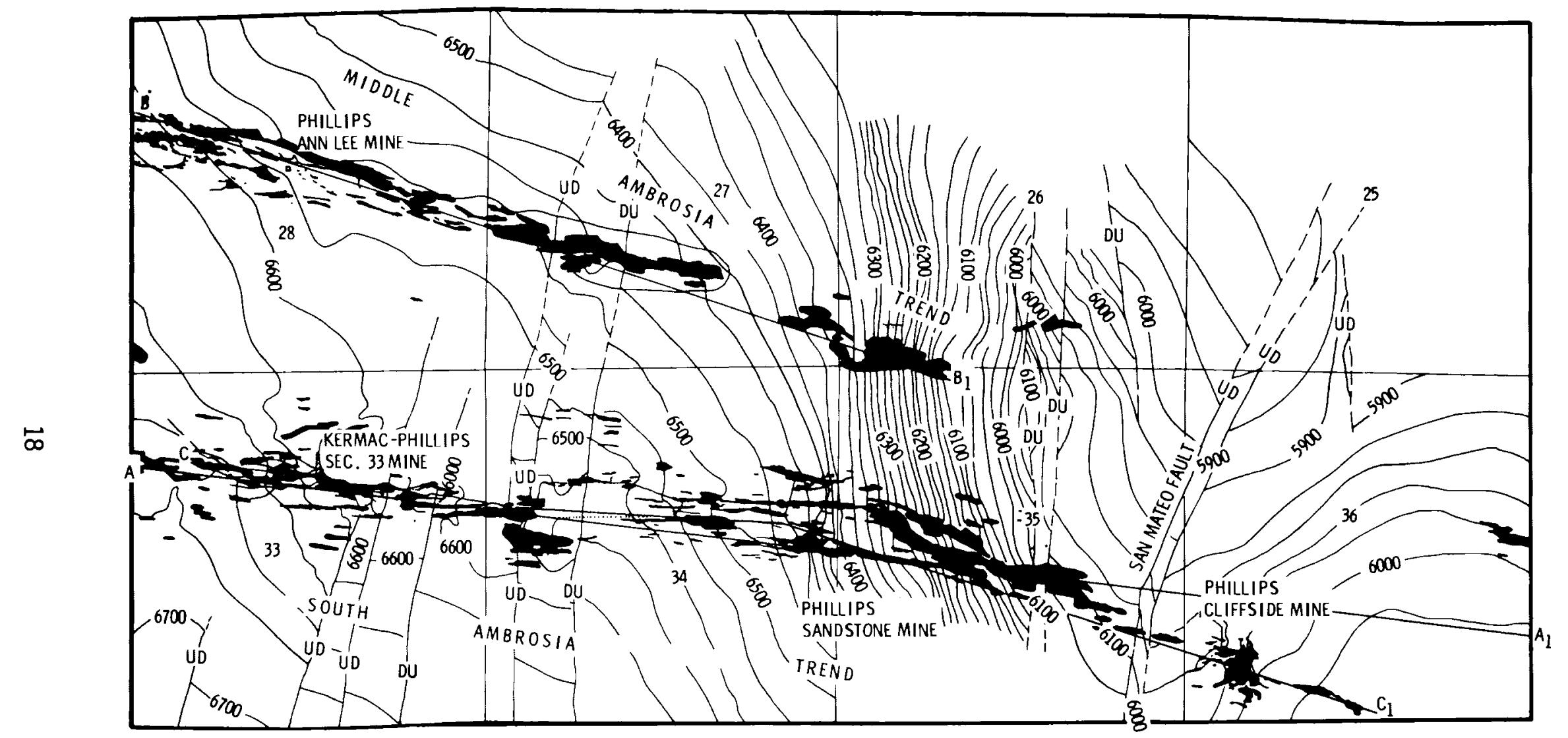

FIGURE 8. Ore Distribution and Structure Contour Map of the Southeastern Ambrosia Lake Area 


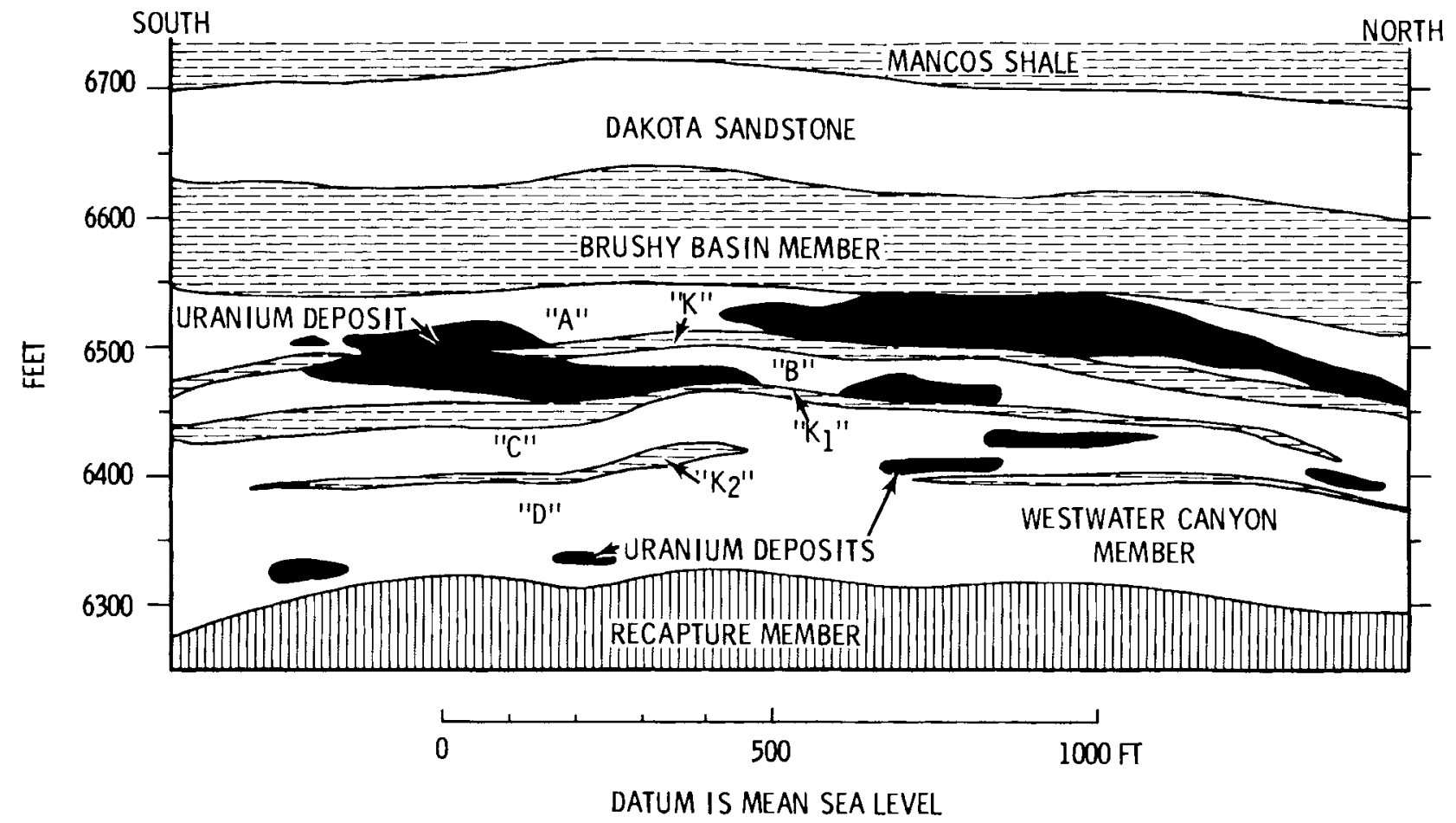

FIGURE 9. Relationship of Uranium Deposits to the Stratigraphic Units 
Individual lenses of ore have migrated over time by dissolution and reprecipitation, and there is evidence the process is continuing in some areas at present (Kelley 1963).

\section{Shirley Basin}

The uranium deposits of the Shirley Basin in Wyoming are associated with two large tongues of altered sandstone (see Figure 10) (Harshmann 1968). The source of the uranium is believed to be from the Granite Mountains and tuffaceous beds of the White River Formation. Ground water issuing from the tuffaceous beds contains 10 to $20 \mathrm{ppb}$ uranium, and ground water present in the wind

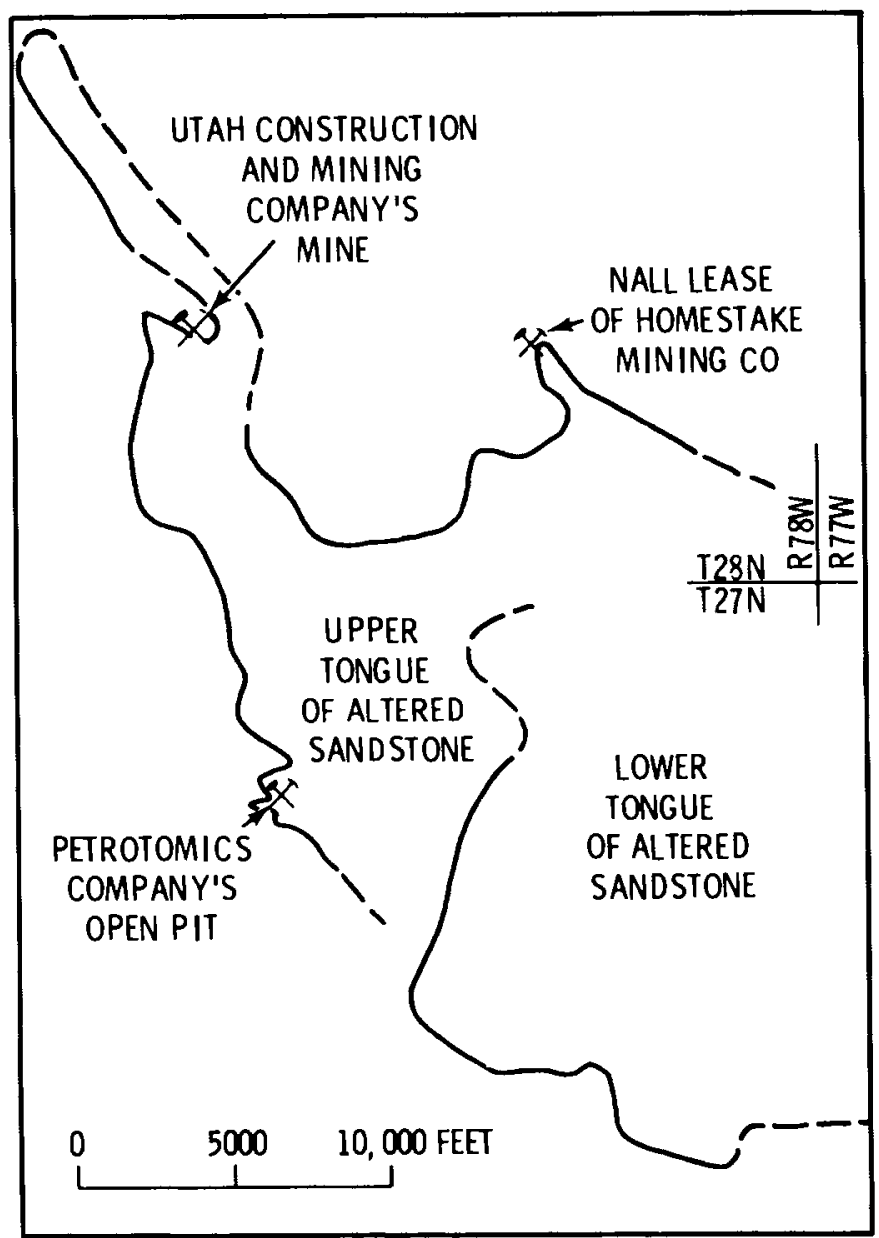

FIGURE 10. Upper and Lower Altered Sandstone Tongues of the Shirley Basin in Wyoming 
River Formation contains $20 \mathrm{ppb}$ uranium, $10 \mathrm{pCi} / \mathrm{L}$ radium, with a $\mathrm{pH}$ of 7.5 to 8.0. The ground-water table is at depths of a few feet to $300 \mathrm{ft}$ below surface and the ground-water gradient is 10 to $30 \mathrm{ft} / \mathrm{mi}(0.19 \%$ to $0.57 \%)$. The principal anions in the ground water are bicarbonate $+200 \mathrm{ppm}$ and sulfate $1000 \mathrm{ppm}$ (Harshmann 1968).

The estimated known resource of uranium in the Shirley Bas in upper tongue is 32,000 tonne, equivalent to $11,000 \mathrm{C} i$; in the lower tongue it is 7000 tonne, equivalent to $2300 \mathrm{Ci}$. The deposits were formed in a sandstone host rock with a median thickness of $30 \mathrm{ft}$ and a median width of 19,800 ft for the upper tongue and 15,800 ft for the lower tongue. The median permeability of the strata is $750 \mathrm{ft} / \mathrm{yr}$, and the median gradient is $1.7 \%$. Ground water flowing through the strata at a rate of $12.8 \mathrm{ft} / \mathrm{yr}$ for 17 million years carried 44,000 tonne of uranium and precipitated an estimated $75 \%$ in the upper tongue. An estimated $20 \%$ from 35,000 tonne uranium flowing through that system was precipitated in the lower tongue (Golabi and Lamont 1978).

Gas Hills

The uranium deposits of the Gas Hills District in Wyoming occur in a coarse-grained arkosic sandstone of the Wind River Formation. The source of the host rock was the granitic core of the Granite Mountains (Love 1970). The estimated known resource of uranium in the Gas Hills District is 68,000 tonne $(\sim 23,000 \mathrm{Ci} \mathrm{U}-238)$. The median thickness of the host sandstone is $150 \mathrm{ft}$, the median width of the aquifer is $53,000 \mathrm{ft}$. The median permeability of the strata is $750 \mathrm{ft} / \mathrm{yr}$ with a median gradient of $1.7 \%$. Ore formation occurred over 20 million years by precipitation from ground water containing $15 \mathrm{ppb}$ uranium and flowing at a rate of $12.8 \mathrm{ft} / \mathrm{yr}$. An estimated $10 \%$ to $30 \%$ of the uranium was precipitated in mineable deposits of economic value (Golabi and Lamont 1978).

\section{Granite Mountain Deposit}

The Granite Mountains in Wyoming, represent a granitic source rock that contained 20 to $30 \mathrm{ppm}$ uranium 60 million years ago but today contains only 2 to $5 \mathrm{ppm}$ uranium. The total uranium content originally present is estimated to be between 7.0 to $10 \times 10^{7}$ tonne in an area of 1600 to $4800 \mathrm{~km}^{2}$ and $390 \mathrm{~m}$ thick (Rosholt and Bartel 1969). 


\section{Rössing Deposit}

The Rössing deposit in Namibia (formerly South West Africa) produces nearly 4000 tonne/yr uranium from 44,400 tonne/day of ore containing $300 \mathrm{ppm}$ uranium. The total uranium content in the deposit is about $6 \times 10^{7} \mathrm{~kg}$. The deposit is about $700 \mathrm{~m}$ in diameter and has a thickness of about $300 \mathrm{~m}$, containing a volume of $1.2 \times 10^{8} \mathrm{~m}^{3}$ of uranium-bearing granite. The deposit is in the Namib Desert, a very dry location (annual rainfall is about 1 in./yr). The deposit is near the edge of the Khan River Basin, but the river contains water only when there is runoff from the infrequent rains. The leaching of uranium from the deposit is included here because it approximates the inventory of a waste repository, is an example of a granitic deposit, and is being commercially mined.

Uranium Deposits at Depth

Uranium deposits can occur at the surface or at any distance below the surface. Uranium is being recovered from depths in excess of $10,000 \mathrm{ft}$ as a by-product of gold mining in South Africa. The uranium deposits at 0klo, Gabon are thought to have been buried as deep as $30 \mathrm{~km}$ by sediments before being exposed near surface by uplift and erosion. Knowledge of uranium at great depth is limited because exploration is not economical. However, in 1977 underground mines produced $80 \%$ of U.S. uranium, and $18.6 \%$ of the uranium came from 800 to $2600 \mathrm{ft}$ below the surface. The distribution of uranium production in 1977 by depth of ore is shown in Table 2 (U.S. Department of Energy 1978). The locations of some significant underground uranium mines in the United States are shown in Figure 11 and some are listed in Table 3 (Dayton 1978, p. 73, 76, 99, 100, 105, and 137; Arnold and Hill 1980).

\section{RADIOACTIVE ELEMENTS IN GROUND AND SURFACE WATERS}

The concentration of uranium and radium in ground water in the United States ranges from 0.1 to $120 \mu \mathrm{g} / \mathrm{L}(\mathrm{ppb}$ ) with a median of about $1.5 \mathrm{ppb}$ (Davis and Dewiest 1966) for uranium and from 0.1 to $29 \mathrm{pCi} / \mathrm{L}$ with a median close to $0.3 \mathrm{pCi} / \mathrm{L}$ (Davis and DeWiest 1966) for radium. Averages for ten geotectonic regions in the United States are shown in Table 4 (Scott and Barker 1962, p. 12), and the corresponding geotectonic regions are shown in Figure 12 . 
TABLE 2. Distribution by Depth of Ore of 1977 U.S. Uranium Production

\begin{tabular}{|c|c|c|c|}
\hline $\begin{array}{l}\text { Depth of } \\
\text { Ore, ft } \\
\end{array}$ & $\begin{array}{l}\text { Uranium, } \\
\text { tons } \\
\end{array}$ & $\begin{array}{l}\text { Percent } \\
\text { of Total }\end{array}$ & $\begin{array}{l}\text { No. of } \\
\text { Sources }\end{array}$ \\
\hline $0-100$ & 760 & 5 & 105 \\
\hline $100-200$ & 3,480 & 25 & 60 \\
\hline $200-300$ & 1,780 & 13 & 35 \\
\hline $300-400$ & 1,870 & 13 & 20 \\
\hline $400-500$ & 850 & 6 & 20 \\
\hline $500-600$ & 1,190 & 8 & 7 \\
\hline $600-700$ & 930 & 7 & 15 \\
\hline $700-800$ & 340 & 2 & 4 \\
\hline $800-2,600$ & 2,630 & 19 & 11 \\
\hline Others & 340 & 2 & 37 \\
\hline Tota 1 & 14,160 & 100 & 314 \\
\hline
\end{tabular}

Surface waters (rivers/lakes) have an average uranium content of $0.1 \mathrm{ppb}$ and the oceans about $1 \mathrm{ppb}$ (Deffeyes and Macgregor 1978).

Hydrogeology of Uranium Deposits

The mobility of uranium and its daughters in the environment depends primarily on ground and surface waters as vehicles. The chemical composition of the water governs the uranium solubility, and the permeability of aquifers and hydraulic gradients controls the rate of movement.

Solubility of Uranium Minerals

The most important component of ground water in solubilizing uranium is its dissolved oxygen content. The solubility of oxygen in water is $8 \mathrm{ppm}$ at sea level, reducing to $7 \mathrm{ppm}$ at $5000 \mathrm{ft}$ equivalent atmospheric pressure.

The natural uranium concentration in ground water from strata in or adjacent to ore bodies within the Grants Mineral Belt is on the order of $60 \mathrm{ppb}$ or less. The concentration of radium rarely exceeds $10 \mathrm{pCi} / \mathrm{L}$ and is commonly less than $5 \mathrm{pCi} / \mathrm{L}$ (EPA 1975). Analysis of well water from the Westwater Canyon Member of the Morrison Formation is shown in Table 5 (Hiss 1977, p. 51). 


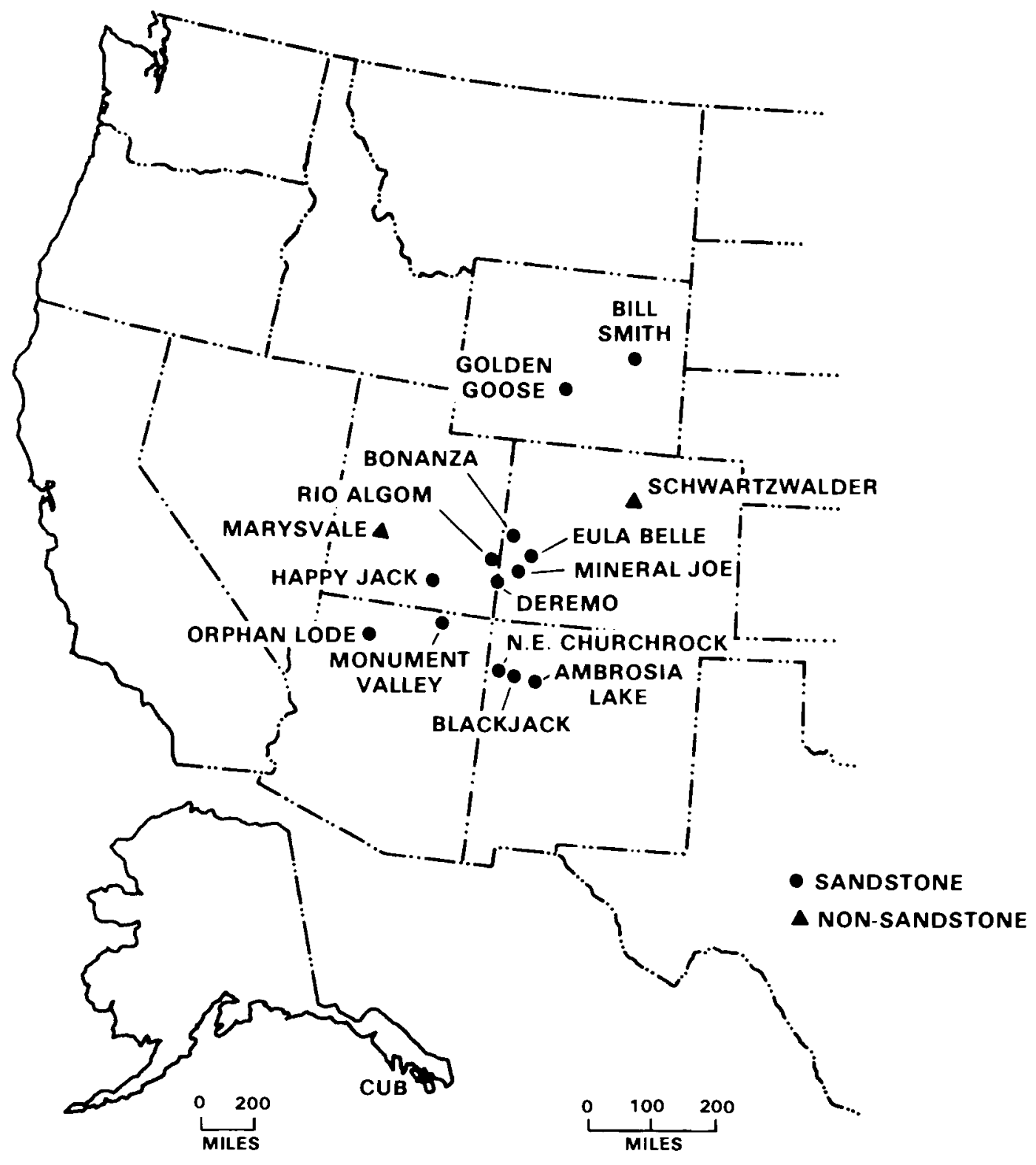

FIGURE 11. Significant Underground Uranium Mines

Figure 13 shows the solubility of $\mathrm{UO}_{2}$ in water at various values of $\mathrm{pH}$ (Langmuir 1978) and the range of $\mathrm{pH}$ values for Grants Mineral Belt ground water (EPA 1975). Also shown are individual values of uranium concentration and $\mathrm{pH}$ for water from wells and other sources in Grants Mineral Belt (EPA 1975). While $\mathrm{UO}_{2}$ is very insoluble, $\mathrm{U}^{+6}$ in oxidizing water is quite soluble as uranyl complexes with fluoride, phosphate, or carbonate ions. 
TABLE 3. Underground Uranium Mines in the United States

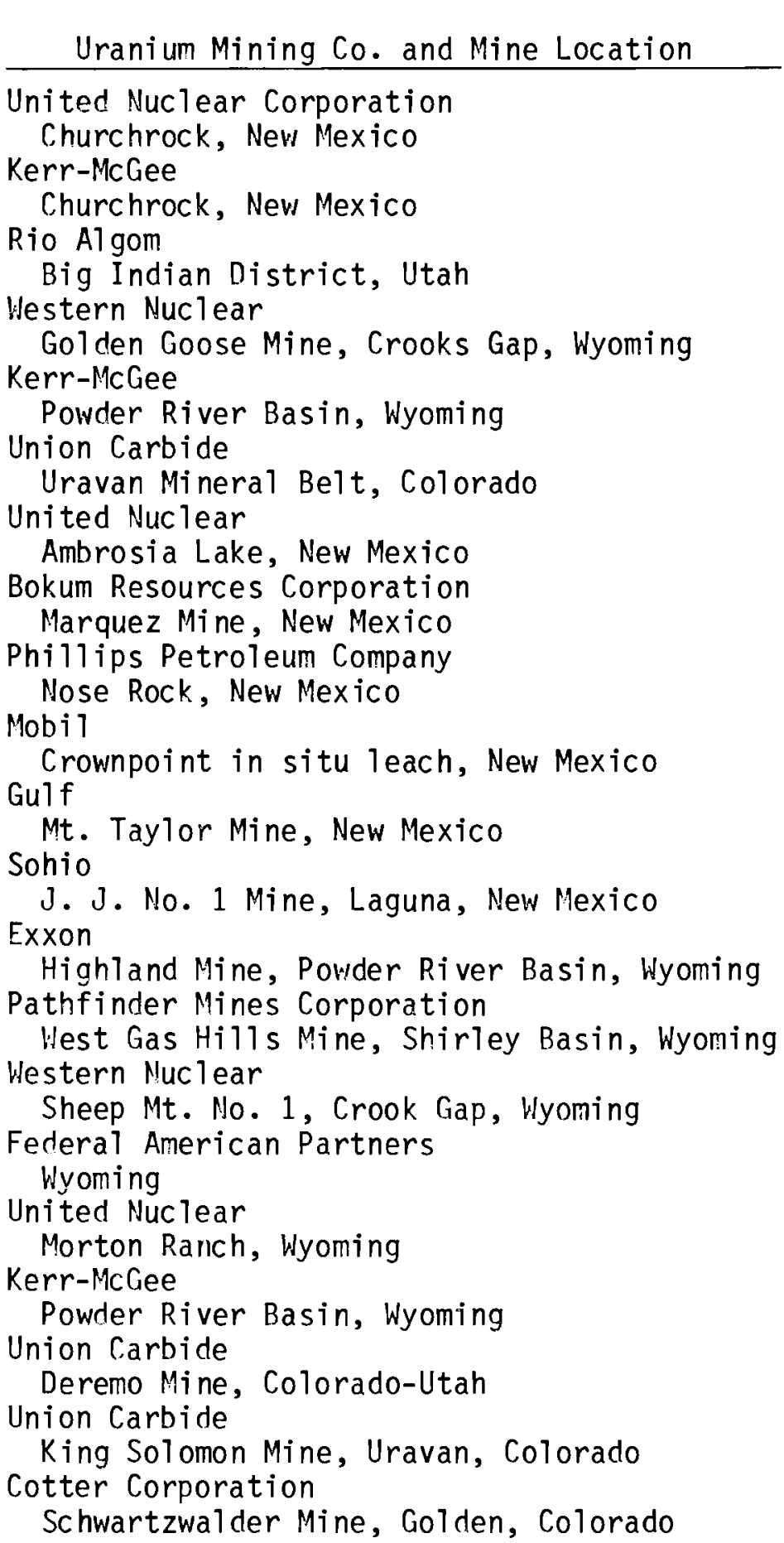

\begin{tabular}{|c|c|}
\hline Depth, ft & $\begin{array}{l}\text { Ore Grade } \\
\Delta \text { Uranium }\end{array}$ \\
\hline 1,800 & --- \\
\hline 1,850 & 0.17 \\
\hline 2,800 & --- \\
\hline 400 & --- \\
\hline 950 & --- \\
\hline $100-800$ & --- \\
\hline 850 & --- \\
\hline 2,150 & --- \\
\hline 3,400 & -- \\
\hline 2,000 & --- \\
\hline 3,370 & -- \\
\hline 672 & 0.13 \\
\hline 700 & --- \\
\hline 300 & --- \\
\hline 1,400 & --- \\
\hline 1,050 & -- \\
\hline 630 & -- \\
\hline 870 & -- \\
\hline 750 & -- \\
\hline 156 & --- \\
\hline 2,000 & 0.27 \\
\hline
\end{tabular}


TABLE 4. Concentration of Uranium and Radium in U.S. Ground Water

\begin{tabular}{|c|c|c|c|c|c|}
\hline $\begin{array}{l}\text { Geotectonic } \\
\quad \text { Region } \\
\text { (Figure 12) }\end{array}$ & $\begin{array}{l}\text { Number } \\
\text { of } \\
\text { Samples }\end{array}$ & $\begin{array}{l}\text { Uranium } \\
\text { Range } \\
\end{array}$ & $\frac{\mu \mathrm{g} / \mathrm{Ll}}{\text { Median }}$ & $\begin{array}{l}\text { Radium } \\
\text { Range }\end{array}$ & $\frac{p C i / L)}{\text { Median }}$ \\
\hline I & 86 & $0.1-15$ & 0.2 & $0.1-8.6$ & 0.2 \\
\hline II & 77 & $0.1-24$ & 0.5 & $0.1-3.3$ & 0.1 \\
\hline I I I & 17 & $0.1-1.5$ & 0.5 & $0.1-1.5$ & 0.1 \\
\hline IV & 7 & $0.2-4.3$ & 1.1 & $0.1-2.6$ & 0.1 \\
\hline v & 75 & $0.1-8.9$ & 0.5 & $0.1-22$ & 0.6 \\
\hline VI & 72 & $0.1-120$ & 2.2 & $0.1-11$ & 0.3 \\
\hline VII & 12 & $0.1-0.6$ & 0.3 & $0.1-2.3$ & 1.0 \\
\hline VIII & 108 & $0.1-37$ & 1.7 & $0.1-29$ & 0.1 \\
\hline IX & 13 & $0.1-6.1$ & 0.8 & $0.1-5.5$ & 0.1 \\
\hline$x$ & 42 & $0.1-7.6$ & 0.2 & $0.1-2.5$ & 0.1 \\
\hline
\end{tabular}

\section{Formation of Uranium Deposits}

The formation and migration of uranium ore deposits are shown pictorially in Figure 14. Oxygenated ground water carrying dissolved uranium derived from nearby source rocks enters a sandstone aquifer in its recharge area. Groundwater flows in the sandstone under influence of gradient and the permeability of the aquifer. Carbonaceous matter and sulfides react with and deplete oxygen dissolved in the ground water. Dissolved uranium is then reduced by carbonaceous matter and by sulfides; the reduced form is insoluble and precipitates forming a deposit. Oxygenated ground water from the recharge area flows through the oxidized rock with loss of oxygen until encountering the roll front where oxygen is then consumed. Eventually, uranium is dissolved at the trailing edge of the roll front and transported to the advancing edge where it again precipitates. The advance rate of a roll front, measured by Russian geologists with similar rates accepted by American geologists, is on the order of 


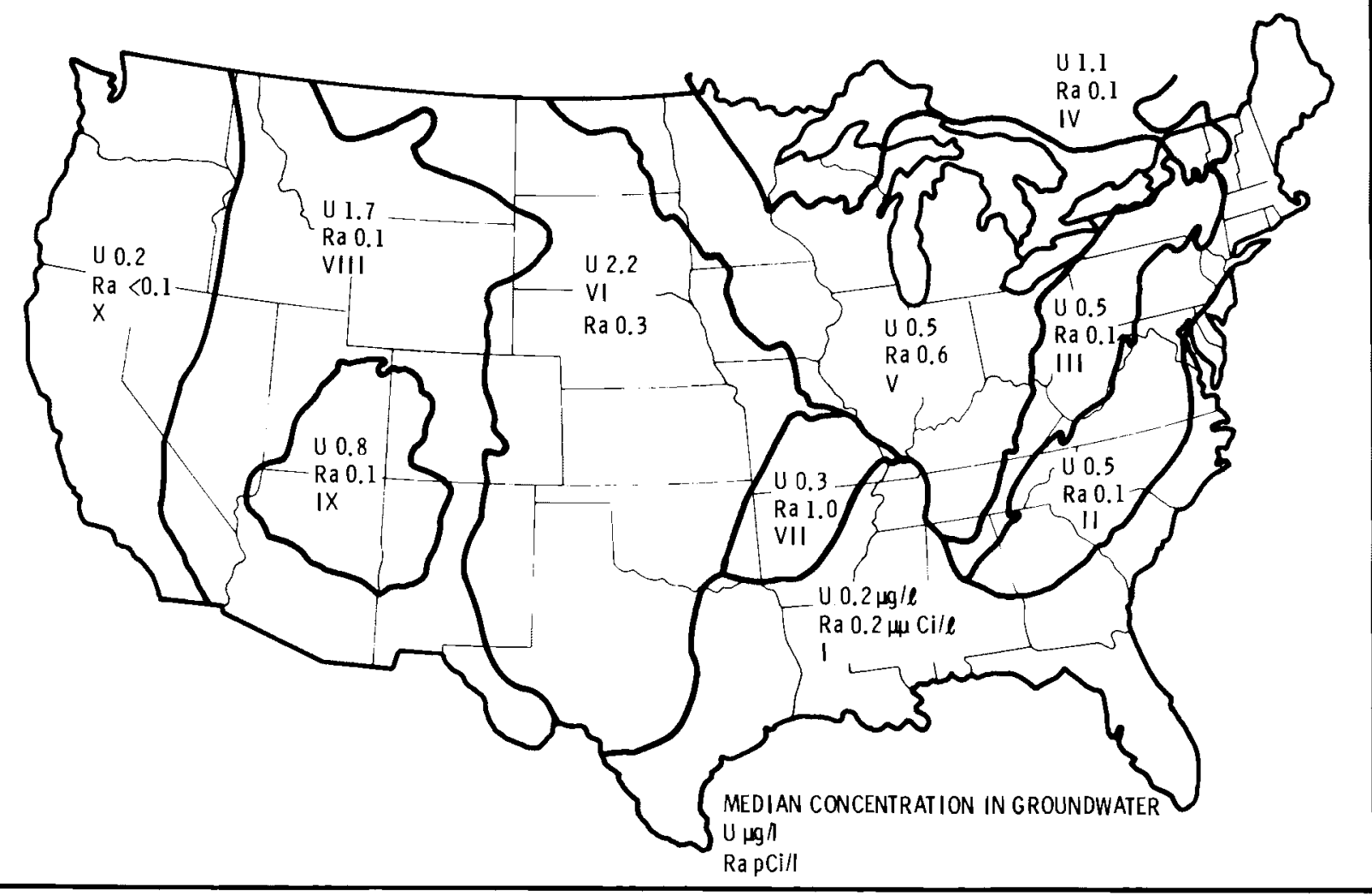

FIGURE 12. Median Concentration of Uranium and Radium in Ground Water in the Geotectonic Regions of the Conterminous United States

$0.1 \mathrm{~cm} / \mathrm{yr}$. At this rate, roll fronts in wyoming, which are found 11 to $13 \mathrm{~km}$ from the nearest recharge area, have been migrating for 11 to 13 million years. Presence of Water at Depth

The primary long-term hazard from either a spent-fuel repository or a large ore deposit is due to the possibility that ground water may transport radioactive elements to the surface. The presence of water, its quantity, flow rate, and chemical composition are factors that govern the extent of the hazard. If exclusion of water could be assured, no such hazard would exist. Water is present in rock at considerable depths occupying pores and fractures. Sedimentary rocks contain water at depths of 50,000 ft and hard igneous rocks 
TABLE 5. Dissolved Chemical Constituents in Water from Grants Mineral Belt ${ }^{(a)}$

\begin{tabular}{|c|c|}
\hline Chemical Constituents & Concentration, ppm \\
\hline $\mathrm{SiO}_{2}$ & 18 to 43 \\
\hline $\mathrm{Fe}$ & 0 to 0.01 \\
\hline Mn & 0 to 0.16 \\
\hline $\mathrm{Ca}$ & 1.9 to 39 \\
\hline $\mathrm{Mg}$ & 0 to 0.5 \\
\hline $\mathrm{Na}$ & 120 to 250 \\
\hline K & 1.1 to 2.5 \\
\hline $\mathrm{HCO}_{3}$ & 166 to 244 \\
\hline $\mathrm{CO}_{3}$ & 0 to 12 \\
\hline $\mathrm{CO}_{2}$ & 0.5 to 2.1 \\
\hline Alkalinity as $\mathrm{CaO}_{3}$ Total & 220 to 136 \\
\hline $\mathrm{SO}_{4}$ & 55 to 490 \\
\hline $\mathrm{Cl}$ & 5.3 to 17 \\
\hline $\mathrm{F}$ & 0.3 to 1 \\
\hline Nitrate + Nitrate as $\mathrm{N}$ & 0.03 to 0.05 \\
\hline Orthophosphate as P & 0.13 to 0.14 \\
\hline Orthophosphate as $\mathrm{PO}_{4}$ & 0.40 to 0.43 \\
\hline Natural Uranium & 0.07 to $0.09^{(b)}$ \\
\hline Radi um-226 & 0.05 to $0.24^{(c)}$ \\
\hline
\end{tabular}

(a) The $\mathrm{pH}$ is 8.1 to 8.9 .

(b) Concentration is in ppb.

(c) Concentration is in $\mathrm{pCi} / \mathrm{L}$.

at perhaps $10,000 \mathrm{ft}$. Depths greater than 100,000 ft are at temperatures and pressures that close all pores and openings, and water is present only in chemical combination with rock minerals. At the $100,000-\mathrm{ft}(30.5-\mathrm{km})$ depth, the pressure is about $165,000 \mathrm{psi}$ and the temperature is about $550^{\circ} \mathrm{C}$. At this temperature sediments are converted to granite (granitization). Depths at which entry of water is precluded are too great for practical consideration. 


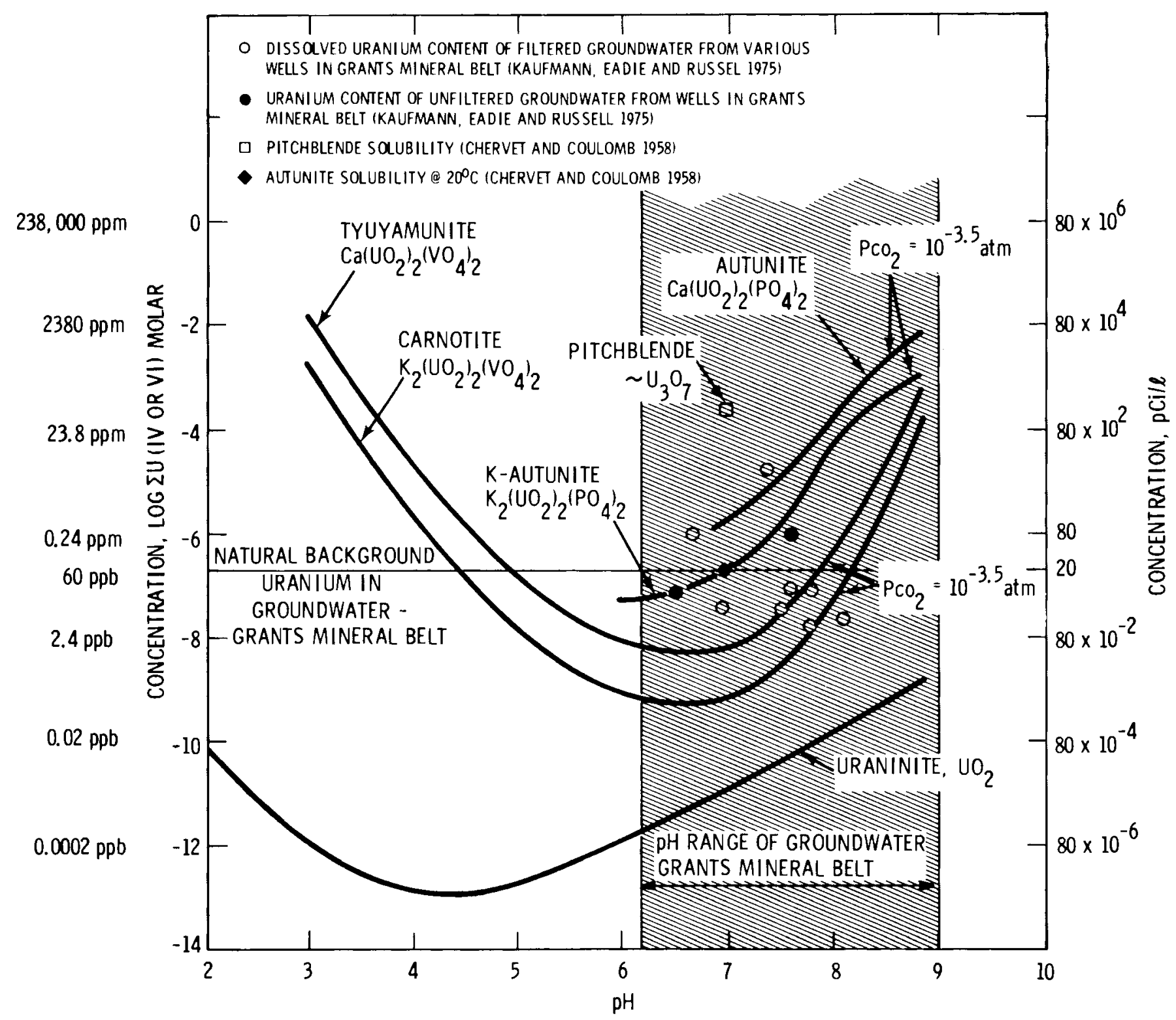

FIGURE 13. Solubility of Uranium Minerals at $25^{\circ} \mathrm{C}$ Under Air at Atmospheric Pressure. NOTE: Solubility curves are based on research by Langmuir (1978). Atmospheric pressure of $\mathrm{CO}_{2}$ is $10^{-3.5} \mathrm{~atm}$; oxygen is $10^{-0.68} \mathrm{~atm}$. 


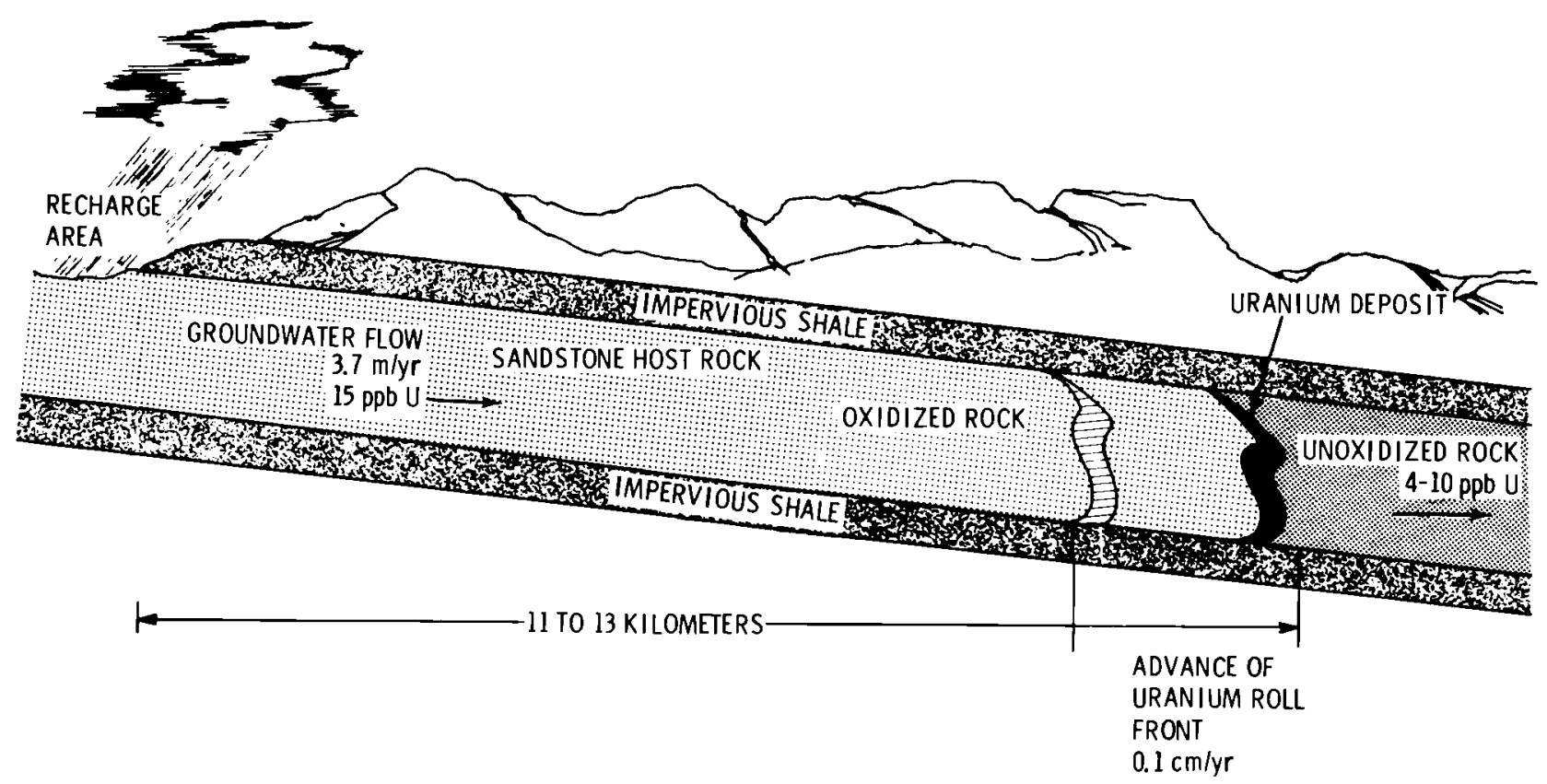

FIGURE 14. Formation and Migration of Uranium Deposits in Sandstone Host Rocks

COMPARISON OF NATURAL DEPOSITS AND WASTE REPOSITORIES

The inventory of uranium-238 in the reference nuclear-waste repository is $24,000 \mathrm{Ci}$ or 72,000 tonne of uranium. This quantity of uranium is dispersed over 2,000 acres $\left(3.13 \mathrm{mi}^{2}\right)$ in the form of 156,000 spent PWR fuel elements with a density of 92 fuel elements per acre or approximately $1 / 100$ acre per each $460-\mathrm{kg}$ fuel element. The zone occupied by the fuel elements is $3.8 \mathrm{~m}$ thick; if the uranium were uniformly distrihuted throughout the zone, its average concentration would be $0.16 \%$.

The uranium inventory of a natural deposit can be as large or larger than that specified for a nuclear-waste repository. However, the distribution of natural deposits is controlled by chemical and geological factors and, therefore, does not simulate the precise arrangement of an engineered waste repository. Also, the full extent of natural uranium occurrences is not known nor does uranium concentration in natural deposits ever approach the concentration in a fuel element.

The Grants Mineral Belt in New Mexico has an inventory of 423,000 tonne of uranium. The Shirley Basin in Wyoming has known uranium resources of 
39,000 tonne while the Gas Hills Wyoming District has an inventory of 68,000 tonne. The Grants Mineral Belt is spread over an area of about $90 \mathrm{mi}^{2}$ while the Shirley Basin deposit occurs over an area of $15 \mathrm{mi}^{2}$. The Gas Hills deposit occupies some $10 \mathrm{mi}^{2}$.

The uranium occurs in concentrations of ore pods or roll fronts often along the interface between an oxidized and reduced area of sandstone (see Figure 14). Uranium concentrations in the ore range from a lower economic mining limit of perhaps $0.05 \%$ up to as much as $14 \% \mathrm{U}_{3} \mathrm{O}_{8}$. Individual ore pods may vary from an average of 3000 tonne of ore containing perhaps 5 tonne of uranium to single, large ore bodies of up to 10 million tonne of ore containing 1000 tonne of uranium. Thus the mineable concentrations of uranium ore are as large or larger than the quantity of uranium dispersed in the storage zone of a nuclearwaste repository. A single, small ore pod containing 6 tonne of uranium is equivalent to the uranium in 12 fuel elements and may have a projected area of 0.10 acre versus 0.12 acre for 12 fuel elements.

Natura? uranium occurs at the surface and at depths of 3000 to $4000 \mathrm{ft}$. Most U.S. deposits occur in highly permeable aquifiers which is unlike the location of an engineered waste repository that is away from the surface and in imperveous material. The modeling of a nuclear-waste repository assumes containment failure for any time from 1 to $10^{6}$ years. Natural uranium ore occurrences can be said to be in a state of failure for the past 30, 40 or 50 million years in that they are exposed to ground water in aquifers and have migrated considerable distances since their formation.

Ground water velocity assumed for the waste-repository studies range from 0.1 to $11 \mathrm{~m} / \mathrm{yr}$, whereas actual ground-water velocities in natural uranium ore systems are in the range of $12 \mathrm{ft} / \mathrm{yr}$. Release rates from spent fuel have been assumed at 1 to $10^{-6} \% / y r$, whereas the migration of natural uranium deposits indicate leach rates of approximately $0.15 \% / y r$. Uranium concentrations in ground water in areas of natural uranium deposits are of the order of $60 \mathrm{ppb}$ and the natural concentration of radium is commonly less than $5 \mathrm{pCi} / \mathrm{L}$. The natural concentrations of radium in surface water and ground water, in areas near uranium ore deposits and in regions throughout the United States, frequently exceed the EPA maximum drinking water standard concentration of 
$5 \mathrm{pCi} / \mathrm{L}$. The concentration of uranium in ground water also is anomalous in many areas of the United States that are quite remote from uranium mining areas.

On the basis of this analysis, placing spent fuel in a deep geological repository appears to reduce the hazard from natural radioactive materials occuring in the earth's crust by locating the uranium in impermeable strata without access to oxidizing conditions. Under such conditions even in the event of containment failure the limited solubility of material exposed to limited quantities of water permeating through geologic materials with high adsorptive capacities would restrict migration to less than 0.1 to $1.4 \mathrm{~cm} / \mathrm{yr}$ for most isotopes. This is the estimated migration rate for natural uranium deposits under conditions of oxygen-saturated ground water and permeable strata. 


\section{RADIOLOGICAL CONSEQUENCES COMPARISON}

The first comparison was based on similarities and differences between the intrinsic properties of ore deposits and the proposed reference repositories. This second comparison is based on the potential radiological consequences that may occur from the repositories and the actual and potential radiological consequences from natural ore deposits.

\section{APPROACH AND METHODOLOGY}

This part of the analysis involved three major tasks. The first task attempted to define a "reference" uranium ore deposit, or, failing that, attempted to adequately define one or more large uranium deposits so that the release analysis could be performed. The second task simplified the uraniumdeposit descriptive data to accomplish the release calculations and analyzed the potential release based on dose to a maximally exposed individual ("maximum individual"). The third task compiled data on naturally occurring uranium and radium concentrations in U.S. surface and subsurface waters and converted that data into an equivalent radiological dose to a maximum individual. The dose was based on the same dose model as used in the repository and ore deposit analyses.

In order to partially eliminate uncertainties due to calculated (via transport models) potential nuclide releases versus measured nuclide concentrations, two large ore deposits were treated in the same manner as the reference repositories. Calculated potential consequences from these deposits were then compared to the equivalent calculations for the repositories and to the measured radionuclide concentrations in actual U.S. water resources. Ore Deposit Definition

To develop a representative scenario for naturally occurring uranium ore deposits, a literature search was conducted and contacts were made with members of the U.S. Geologic Survey and DOE Grand Junction office. There is a wealth of information concerning uranium deposits and uranium/radium concentrations in

ground and surface waters. Two uranium deposits briefly described earlier were 
selected to serve as references. The two are Granite Mountain in Wyoming and Rössing in South West Africa. These two sites were picked due to their large inventories of uranium. The Granite Mountain deposit is a widely distributed, lower specific concentration deposit, while the Rössing deposit is a more compact, higher specific concentration deposit.

\section{Granite Mountain Deposit}

The characteristics of this deposit are assumed to be those present nearly 60 million years ago. It has been determined that some granite samples from the Granite Mountain region have lost nearly $80 \%$ of the uranium originally contained in them (Stuckley et a1. 1977). This uranium has been leached away during the last 60 million years. Very little of the leached uranium is present in the area surrounding the Granite Mountain region. It was determined that the granite lost 1000 times as much uranium as there is known to be in reserves in the surrounding sedimentary Wyoming deposits (Rosholt and Bartel 1969).

Assuming that all the leached uranium was returned to the area, the uranium content of the deposit would be about $10^{11} \mathrm{~kg}$. The uranium is spread over an area of between 1600 and $4800 \mathrm{~km}^{2}$. The thickness of the leached granite is about $390 \mathrm{~m}$, containing a volume of uranium-bearing granite of about $10^{12} \mathrm{~m}^{3}$. It was assumed that the ${ }^{238} \mathrm{U},{ }^{234} \mathrm{U},{ }^{230} \mathrm{Th}$, and ${ }^{226} \mathrm{Ra}$ concentrations are in decay equilibrium. The total curies inventory for the deposit is given in Table 6. The flow rate for water through the deposit is not known, but studies have determined the rate through Conway Granite has a range of 0.01 to $0.05 \mathrm{~m} / \mathrm{yr}$ (Fehm, Cathles and Holland 1978).

\section{Rössing Deposit}

The Rössing deposit of South West Africa was chosen due to its high specific activity--between ten and one hundred times that of Granite Mountain. The total uranium content in the deposit is about $6 \times 10^{7} \mathrm{~kg}$. The deposit is about $700 \mathrm{~m}$ in diameter, has a thickness of about $300 \mathrm{~m}$, and contains a volume of $1.2 \times 10^{8} \mathrm{~m}^{3}$ of uranium-bearing granite. The total curie inventory is given in Table A.1. The leaching of uranium from the deposit is slow due to the lack of moisture in the area. 
TABLE 6. Radionuclide Inventories

\begin{tabular}{|c|c|c|c|}
\hline \multicolumn{4}{|c|}{ Initial Inventories, $\mathrm{Ci}$} \\
\hline Nuclide & $\begin{array}{c}\text { Reference } \\
\text { Repositories }\end{array}$ & $\begin{array}{l}\text { Granite } \\
\text { Mountain }\end{array}$ & $\begin{array}{l}\text { Rössing } \\
\text { Deposit }\end{array}$ \\
\hline${ }^{238} U$ & $2.4 \mathrm{E} 4$ & $3.4 \mathrm{E7}$ & $1.9 \mathrm{E} 4$ \\
\hline${ }^{234} U$ & $1.3 \mathrm{E} 5^{(a)}$ & $3.4 \mathrm{E7}$ & $1.9 \mathrm{E} 4$ \\
\hline${ }^{230} \mathrm{Th}$ & 2.9E1 & $3.4 \mathrm{E7}$ & $1.9 \mathrm{E} 4$ \\
\hline${ }^{226} \mathrm{Ra}$ & $2.9 \mathrm{E}-1$ & $3.4 \mathrm{E} 7$ & $1.9 \mathrm{E} 4$ \\
\hline${ }^{129} 9_{I}$ & $2.5 \mathrm{E} 3$ & -- & -- \\
\hline${ }^{99} \mathrm{TC}$ & $9.6 \mathrm{E} 5$ & -- & -- \\
\hline${ }^{14} \mathrm{C}$ & $2.5 \mathrm{E} 4$ & -- & -- \\
\hline${ }^{241} \mathrm{Am}$ & 2.3E8 & -- & -- \\
\hline${ }^{237} \mathrm{~Np}$ & 2.5E4 & -- & -- \\
\hline
\end{tabular}

(a) Includes ingrowth from 238pu during first 1000 years.

\section{Potential Consequences Analysis}

The descriptive data for the uranium ore deposits were combined with other data needed for the nuclide-transport calculations. The methodology applied was identical to that of Burkholder et a1. (1976), Cloninger, Cole and Washburn (1980), and Cloninger and Cole (1980), using a new FORTRAN version of the GETOUT (DeMier et a1. 1979) nuclide-transport code. The biosphere-transport code, PABLM (Napier, Kennedy and Soldat 1980), is the same as that used in the Commercial Waste Management/Generic Environmental Impact Statement (CWM/GEIS) (U.S. Department of Energy 1979). These models were applied to predict the potential radiological consequences from the two example ore deposits in a manner consistent with the analyses of the reference repositories. A brief description follows giving the models, the scenario, and the development of the remaining descriptive data for the ore deposits.

The Models

The geosphere transport model is a second-generation FORTRAN version of the GETOUT code (DeMier et al. 1979). The model is a one-dimensional 
analytical type that 1) simulates the radionuclide release from a repository through contact and leaching by flowing ground water with simultaneous transport of the nuclides in the ground water (including the effects of convection, hydrodynamic dispersion, reversible sorption and mineralization, and radioactive decay), and 2) predicts the ultimate time and rate of nuclide release to the surface water (lake or river) or water well intake.

The major hydrologic parameters are the dispersivity, ground-water flow rates, and total pathlength to the biosphere. These parameters are functions of geologic media factors such as porosity, permeability, net hydraulic head and gradient, and fracture patterns. For this analysis, these parameters have been reduced to net ground-water flow velocity, total migration pathlength, and a net dispersion coefficient. The flow velocity and pathlength, though modeled separately, are combined for graphic presentation into a single parameter, ground-water travel time (pathlength/flow velocity).

Output data of the geosphere model are the input data for the biosphere model, PABLM (Napier, Kennedy and Soldat 1980). The biosphere model predicts the human radiation dose from the nuclide release to surface waters via several pathways, including direct ingestion of water, aquatic foods and irrigated food products, as well as irradiation from shoreline deposition and swiming. Food chain reconcentration/accumulation effects are included.

\section{The Scenario}

The highest risk path from the ore deposit and repository through the geosphere to the biosphere is assumed to be the leach-incident pathway. While the relative risks of the various pathways have not all been evaluated, the leach incident appears to be the highest probability release process.

The leach-incident scenario involves the following steps:

- penetration of the repository by ground water

- failure of the waste container

- leaching of the radionuclides from the waste form

- transport of the nuclides through the surrounding geology to the biosphere 
- transport of the nuclides through the biosphere to man

- interaction of the nuclides with man.

A pictorial representation of this scenario is shown in Figure 15 (Cloninger, Cole and Washburn 1980).

One difference between a repository and an ore deposit in the scenario is that the failure of the waste container is not part of the ore deposit release. The "waste form" in the case of the ore deposit is the ore itself.

The scenario has two subsets, a general scenario and an intrusion water well scenario. The general scenario consists of the six steps above with release to surface water (lake or river) as the biosphere entry point. The human-caused intrusion water well scenario can essentially short-circuit the protection that the geologic system provides from nuclides already dissolved in the ground water. The intrusion-well scenario was chosen as a limiting case of the leach-incident pathway.

The biosphere parameters for the general scenario are identical to those used in the CWM/GEIS (U.S. Department of Energy 1979) and in the studies by Cloninger, Cole and Washburn (1980) and Cloninger and Cole (1980). The parameters for the well scenario are those used by Cloninger and Cole (1980). Uranium-Radium Concentrations in U.S. Waters

Uranium and radium are found in almost every source of surface or subsurface water. The levels of activity differ from location to location, with the water sources that traverse uranium-bearing formations containing a higher concentration. It has been proposed that these high-concentration water sources be used as an indicator of potentially mineable uranium deposits. Table 7 lists some uranium and radium concentrations that have been found in ground or surface waters of the United States. These concentrations were used in conjunction with the biosphere model to estimate the potential dose consequences due to a maximum individual's use of these waters for all of his water needs. 


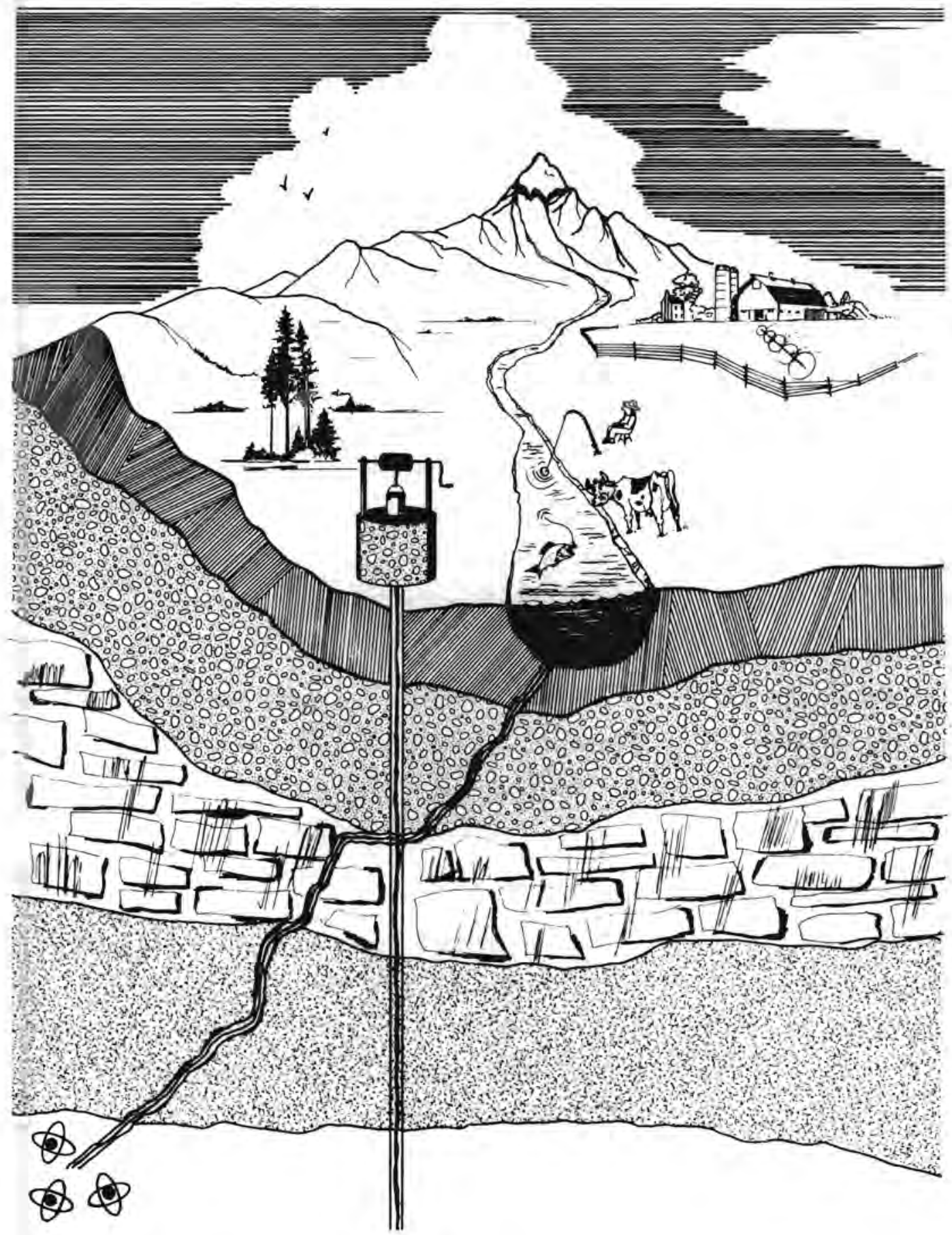

FIGURE 15. Pictorial Representation of the Leach-Incident Scenario 
TABLE 7. Reported Nucl ide Concentrations in

U.S. Surface and Subsurface Waters

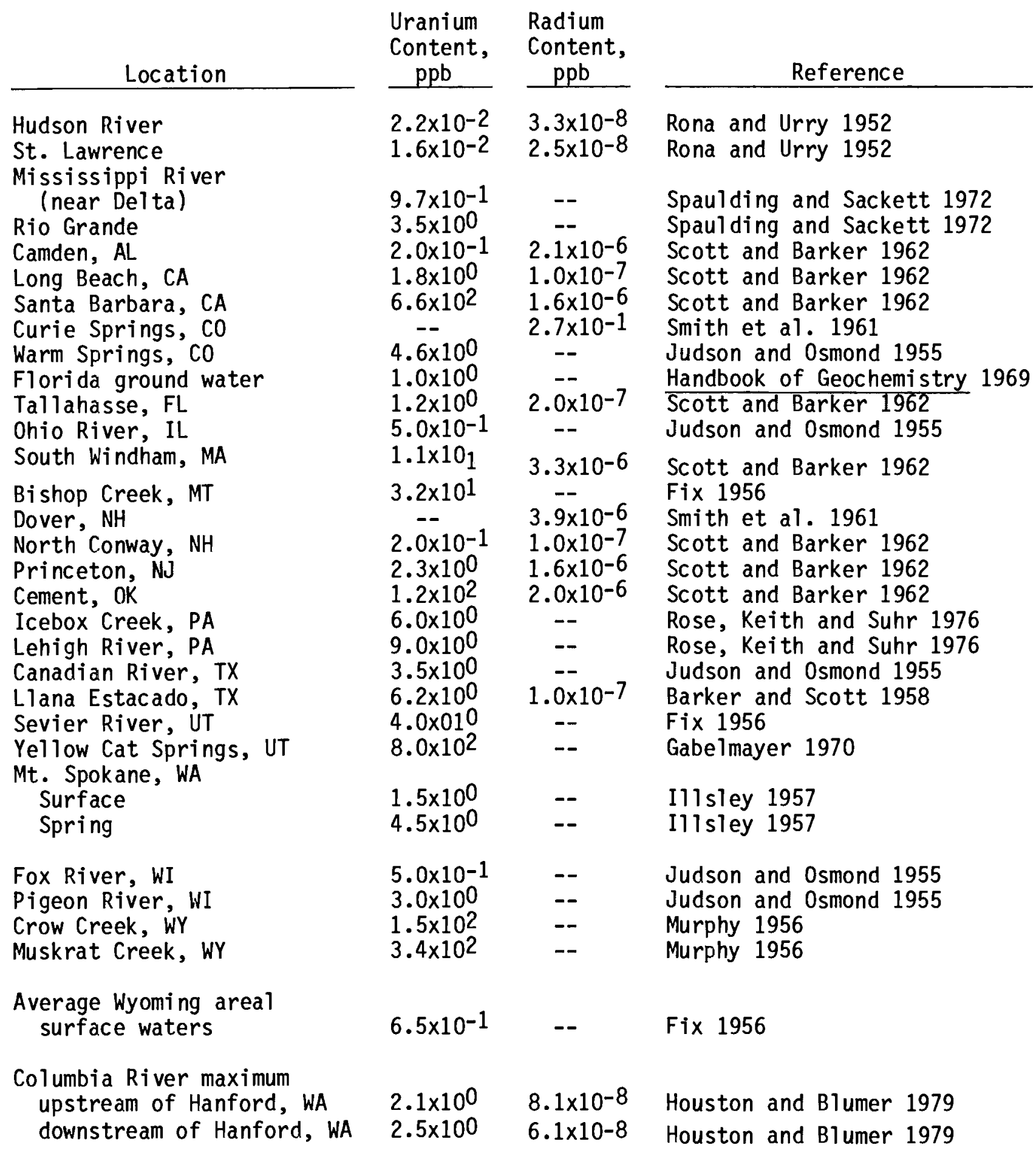


APPLICATION TO THE ORE DEPOSITS

The ground water velocity used for the Granite Mountain calculations was a factor of five times the maximum estimated for the Conway Granite System $(0.05 \mathrm{~m} / \mathrm{yr})$, a value of $0.22 \mathrm{~m} / \mathrm{yr}(0.72 \mathrm{ft} / \mathrm{yr})$. This value was used in order to avoid numerical difficulties in the dispersion ground-water transport model. At first it was thought that this would lead to an excessively conservative result, however it was found that the result was relatively insensitive to ground-water travel rates due to the extremely long leach duration ( 7.7 to 77 million years) used. In other words, the dispersive effect of the long release duration (low leach rate) was far greater than the convective dispersion effects during ground-water transport.

The sorption coefficients $\left(K_{d}\right)$ for both the Granite Mountain and the Rossing analysis are based on a geologic media which is a hybrid of Swedish bedrock and Nevada Test Site Climax Stock granite quartz monzonite porphyry. The ground water basis for the $k_{d} s$ is similar to Swedish (Rennerfelt 1977) and Los Alamos Scientific Laboratory's analys is of Climax Stock ground water (Serne 1977). The sorption coefficients are listed in Table 8.

TABLE 8. Uranium Deposits Sorption Coefficients, $K_{d}$

$$
\text { Oxic Condition, Anoxic, }
$$

Element $\mathrm{ml} / \mathrm{g}\left(0.2 \mathrm{~atm} 0_{2}\right) \quad \mathrm{ml} / \mathrm{g}$ (negligible $\left.0_{2}\right)$

$\mathrm{Ra} \quad 80$

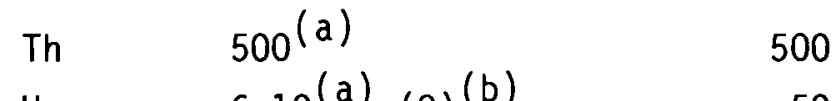

U $6-10^{(a)}(8)^{(b)} \quad 50$

(a) Measured values, others estimated.

(b) Value used where range given.

For application in the GETOUT model, the $K_{d}$ values were incorporated as "K-values" according to the equation:

$$
K=1+\beta K_{d}
$$


where $B$ represents the ratio of geologic material available for sorption to the specific volume available for saturated ground-water flow. The values of $B$ assumed for this work were

$$
\begin{gathered}
\text { Granite Mountain } \beta=3.5 \\
\text { Rössing } \beta=9.0 .
\end{gathered}
$$

In the general scenario, the distance that the ground water traveled from the uranium ore deposit to the surface waters (biosphere entry point) was varied from $1.0 \mathrm{~km}$ to $(0.62 \mathrm{mi})$ to $32 \mathrm{~km}(20 \mathrm{mi})$ for Granite Mountain to cover a range of possibilities due to the size of the system; it was constant at $3.2 \mathrm{~km}(2 \mathrm{mi})$ for the Rössing analysis.

For the 1 imiting well scenario, the pathlengths were reduced to $0.23 \mathrm{~km}$ (0.14 $\mathrm{mi})$ for Granite Mountain and $0.55 \mathrm{~km}(0.34 \mathrm{mi})$ for Rössing, and the ground-water velocity for Granite Mountain was increased to $0.45 \mathrm{~m} / \mathrm{yr}$ $(1.5 \mathrm{ft} / \mathrm{yr})$.

The inventories of dose-significant nuclides for the two uranium deposits and the reference repositories are listed in Table 6 . The inventory of the repositories was based on the CWM/GEIS no-recycle nuclear power industry accumulation of spent fuel, with $1 / 5$ of the total spent fuel sealed into one repository in the year 2050 (U.S. Department of Energy 1979), and is 1isted in detail in Table A.1. A summary of the descriptive data for the geologic transport calculations is given in Table 9.

\section{RESULTS AND DISCUSSION}

Results were compiled from 1) the reference respository studies (Cloninger, Cole and Washburn 1980; Cloninger and Cole 1980), 2) the ore deposits consequence calculations, and 3 ) the measured nuclide concentrations in U.S. waters. This section explains how these study results were combined for the comparison on potential radiological consequences, and it discusses the significance of the results in relating natural ore deposits to radioactive waste repositories. 
TABLE 9. System Parameters for Geologic Transport Calculations

\begin{tabular}{|c|c|c|c|c|}
\hline Site & $\begin{array}{c}\text { Ground Water } \\
\text { Velocity, } \\
\mathrm{m} / \mathrm{yr}\end{array}$ & $\begin{array}{c}\text { Migration } \\
\text { Pathlength, } \\
\text { km }\end{array}$ & $\begin{array}{c}\text { Ground Water } \\
\text { Travel Time, } \\
\text { yr }\end{array}$ & $\begin{array}{l}\text { Leach Rate, } \\
\text { Fraction/yr }\end{array}$ \\
\hline $\begin{array}{l}\text { Reference } \\
\text { Granite } \\
\text { Repository }\end{array}$ & $1.5 \mathrm{E}-2$ to $2.0 \mathrm{E}+0$ & $1.0 \mathrm{E}+0$ to $1.5 \mathrm{E}+1$ & $5.0 \mathrm{E}+2$ to $1.0 \mathrm{E}+6$ & $1.0 \mathrm{E}-2$ to $1.0 \mathrm{E}-6$ \\
\hline $\begin{array}{l}\text { Reference } \\
\text { Salt } \\
\text { Repository }\end{array}$ & $1.7 \mathrm{E}-1$ to $1.1 \mathrm{E}+1$ & $5.6 \mathrm{E}+0$ to $6.4 \mathrm{E}+1$ & $5.0 \mathrm{E}+2$ to $3.7 \mathrm{E}+5$ & $1.0 \mathrm{E}-2$ to $1.0 \mathrm{E}-6$ \\
\hline $\begin{array}{l}\text { Granite } \\
\text { Mountain }\end{array}$ & 2.2E-1 to $4.5 \mathrm{E}-1$ & $2.3 \mathrm{E}-1$ to $3.2 \mathrm{E}+1$ & $5.0 \mathrm{E}+2$ to $1.5 \mathrm{E}+5$ & $1.3 \mathrm{E}-7$ to $1.3 \mathrm{E}-8$ \\
\hline Rössing & $1.1 \mathrm{E}+0$ & $5.5 \mathrm{E}-1$ to $3.2 \mathrm{E}+0$ & $5.0 E+2$ to $2.9 E+3$ & $1.0 \mathrm{E}-7$ \\
\hline
\end{tabular}

Application of the Results

The reported uranium and radium concentrations in U.S. waters (see Table 7) have been converted to a resultant average, annual, total-body dose to the maximum individual (see Table 10) and to a lifetime, critical-organ (bone, in all cases) dose commitment to the maximum individual (see Table 11).

The dose to the maximum individual calculated for Tables 10 and 11 was based on either the reported ${ }^{226} \mathrm{Ra}$ concentration or on the assumption that ${ }^{226} \mathrm{Ra}$ is in decay equilibrium with the reported uranium concentration. The uranium is assumed to be totally ${ }^{238} \mathrm{U}$. It has been found that normal ground water generally contains a higher concentration $(\mathrm{C} i / L)$ of radium than uranium (Muzor 1976) partly due to reconcentration (Burkholder and Cloninger 1978), enhanced solubility due to $\alpha$-recoil and solution chemistry; thus the use of the equilibrium assumption would be considered conservative. However, note that in Table 10, the doses calculated from the equilibrium assumption range from about two orders of magnitude higher (Santa Barbara, California) to about an order of magnitude lower (Camden, Alabama) than those based on the actual ${ }^{226} \mathrm{Ra}$ measurement for the same water. Therefore, the validity of the equilibrium assumption is not strongly supported.

Several of the values from Tables 10 and 11 are shown graphically on Figures $16,17,18$ and 19 for comparison with calculated potential dose consequences for the reference repostories and the two ore deposits. 
TABLE 10. Calculated Average, Annual, Total-Body Dose to Maximum Individual Due to Reported Nuclide Concentrations

\begin{tabular}{|c|c|c|}
\hline Location & $\begin{array}{l}{ }^{226} \text { Ra Dose } \\
\text { from Assumed } \\
\text { Equilibrium } \\
\text { with Uranium }\end{array}$ & $226{ }_{\mathrm{Ra} \text { Dose }}^{\text {Direct }}(\mathrm{a})$ \\
\hline Hudson River & $6.0 \mathrm{E}+0$ & $2.7 \mathrm{E}+1$ \\
\hline St. Lawrence River & $4.4 E+0$ & 2. $0 E+1$ \\
\hline Mississippi River & $2.7 E+2$ & -- \\
\hline Rio Grande & $9.6 \mathrm{E}+2$ & -- \\
\hline Camden, AL & $5.5 \mathrm{E}+1$ & $1.7 E+3$ \\
\hline Long Beach, CA & $4.9 E+2$ & $8.0 E+1$ \\
\hline Santa Barbara, CA & $1.8 \mathrm{E}+5$ & $1.3 E+3$ \\
\hline Curie Springs, CO & -- & $2.2 E+8$ \\
\hline Warm Springs, CO & $1.3 E+3$ & -- \\
\hline Florida ground water & $2.7 E+2$ & -- \\
\hline Ta11 ahassee, FL & $3.3 \mathrm{E}+2$ & $1.6 \mathrm{E}+2$ \\
\hline Ohio River, IL & $1.4 \mathrm{E}+2$ & $0 \overline{7}-\overline{1}$ \\
\hline $\begin{array}{l}\text { South Windham, MA } \\
\text { Bishop Creek, MT }\end{array}$ & $\begin{array}{l}3.0 E+3 \\
8.7 E+3\end{array}$ & $2.7 E+3$ \\
\hline Dover, NH & -- & $3.1 E+3$ \\
\hline North Conway, NH & $5.5 \mathrm{E}+1$ & $8.0 \mathrm{E}+1$ \\
\hline $\begin{array}{l}\text { Princeton, NJ } \\
\text { Cement, OK }\end{array}$ & $\begin{array}{l}6.3 \mathrm{E}+2 \\
3.3 \mathrm{E}+4\end{array}$ & $\begin{array}{l}1.3 \mathrm{E}+3 \\
1.6 \mathrm{E}+3\end{array}$ \\
\hline Icebox Creek, PA & $1.6 \mathrm{E}+3$ & -- \\
\hline Lehigh River, PA & $2.5 E+3$ & -- \\
\hline Canadian River, TX & $9.6 \mathrm{E}+2$ & -- \\
\hline Llano Estacado, TX & $1.7 E+3$ & 8. $0 \mathrm{E}+1$ \\
\hline Sevier River, UT & $1.1 E+3$ & -- \\
\hline Yellow Cat Springs, UT & $2.2 E+5$ & -- \\
\hline Mt. Spokane, WA & & \\
\hline Surface water & $4.1 E+2$ & -- \\
\hline Spring water & $1.2 E+3$ & -- \\
\hline Fox River, WI & $1.4 E+2$ & -- \\
\hline Pigeon River, WI & $8.2 E+2$ & -- \\
\hline Crow Creek, WY & $4.1 E+4$ & -- \\
\hline Muskrat Creek, WY & $9.3 E+4$ & -- \\
\hline Average Wyoming areal & $1.8 \mathrm{E}+2$ & -- \\
\hline $\begin{array}{l}\text { Columbia River maximum } \\
\text { upstream of Hanford, WA }\end{array}$ & $5.7 E+2$ & $6.5 E+1$ \\
\hline
\end{tabular}

(a) Dose to maximum individual, mrem/yr, based on reported nuclide concentrations from Table 7 . 
TABLE 11. Lifetime Critical-Organ Dose Commitment (cumulative) to Maximum Individual Due to Reported Nuclide Concentrations

\begin{tabular}{|c|c|c|}
\hline Location & $\begin{array}{l}{ }^{226} \mathrm{Ra} \text { Dose } \\
\text { from Assumed } \\
\text { Equil ibrium } \\
\text { with Uranium }\end{array}$ & $226_{\mathrm{Ra} \text { Dose }}^{\text {Direct }}(\mathrm{a})$ \\
\hline Hudson River & $6.3 \mathrm{E}-1$ & $2.8 E+0$ \\
\hline St. Lawrence River & $4.6 E-1$ & $2.1 E+0$ \\
\hline Mississippi River & $2.8 \bar{E}+1$ & -- \\
\hline Rio Grande & $1.0 \mathrm{E}+2$ & -- \\
\hline Camden, AL & $5.7 \mathrm{E}+0$ & $1.8 E+2$ \\
\hline Long Beach, CA & $5.2 \bar{E}+1$ & $8.4 E+0$ \\
\hline Santa Barbara, CA & $1.9 E+4$ & $1.4 E+2$ \\
\hline Curie Springs, Co & - & $2.3 \mathrm{E}+7$ \\
\hline Warm Springs, CO & 1. $3 E+2$ & -- \\
\hline Florida ground water & $2.9 E+1$ & -- \\
\hline Tallahassee, FL & $3.4 E+1$ & $1.7 \mathrm{E}+1$ \\
\hline Ohio River, IL & $1.4 E+1$ & -- \\
\hline South Windham, MA & $3.2 \mathrm{E}+2$ & $2.8 E+2$ \\
\hline Bishop Creek, MT & $9.2 \mathrm{E}+2$ & -- \\
\hline Dover, NH & -- & $3.3 E+2$ \\
\hline North Conway, NH & $5.7 E+0$ & $8.4 E+0$ \\
\hline Princeton, NJ & $6.6 E+1$ & $1.4 E+2$ \\
\hline Cement, OK & $3.4 E+3$ & $1.7 E+2$ \\
\hline Ic ebox Creek, PA & $1.7 E+2$ & -- \\
\hline Lehigh River, PA & $2.6 \mathrm{E}+2$ & -- \\
\hline Canadian River, TX & $1.0 E+2$ & -- \\
\hline Llano Estacado, TX & $1.8 \mathrm{E}+2$ & $8.4 \mathrm{E}+0$ \\
\hline Sevier River, UT & $1.1 \mathrm{E}+2$ & -- \\
\hline Yellow Cat Springs, UT & $2.3 E+4$ & -- \\
\hline Mt. Spokane, WA & & \\
\hline Surface water & $4.3 E+1$ & -- \\
\hline Spring water & $1.3 E+2$ & -- \\
\hline Fox River, WI & $1.4 \bar{E}+1$ & -- \\
\hline Pigeon River, WI & $8.6 \bar{E}+1$ & -- \\
\hline Crow Creek, WY & $4.3 E+3$ & -- \\
\hline Muskrat Creek, WY & $9.8 E+3$ & -- \\
\hline $\begin{array}{l}\text { Average Wyoming areal } \\
\text { surface waters }\end{array}$ & 1.9E+1 & -- \\
\hline Columbia River maximum & $6.0 E+1$ & $6.8 E+0$ \\
\hline $\begin{array}{l}\text { upstream of Hanford, WA } \\
\text { downstream of Hanford, WA }\end{array}$ & $7.2 E+1$ & $5.1 E+0$ \\
\hline
\end{tabular}

(a) 70-yr bone dose commitment to maximum individual, rem, based on reported nuclide concentrations from Table 7 . 


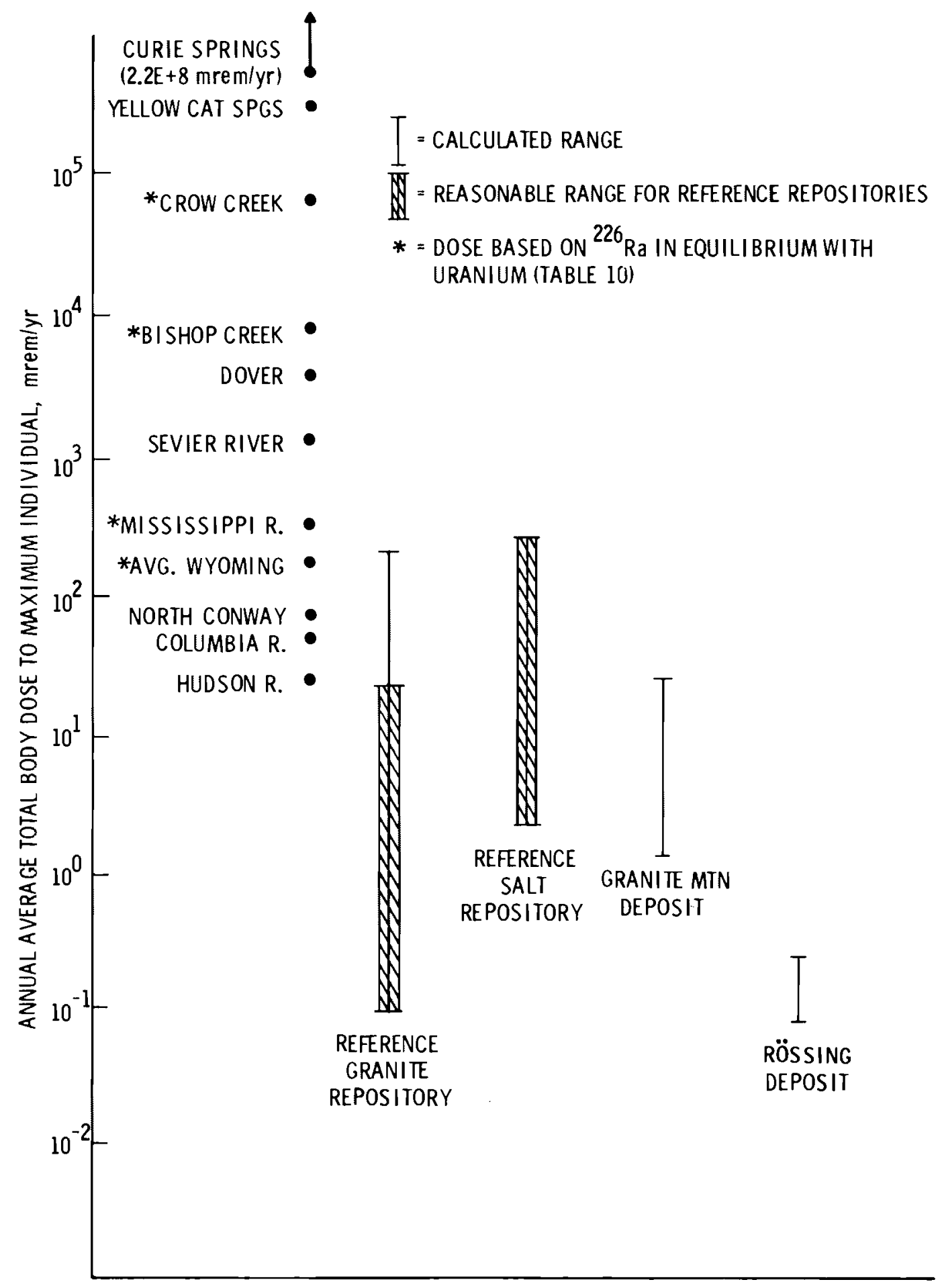

FIGURE 16. Summary of Calculated Potential Radiological Consequences: Average, Annual, Total-Body Dose, General Scenario 


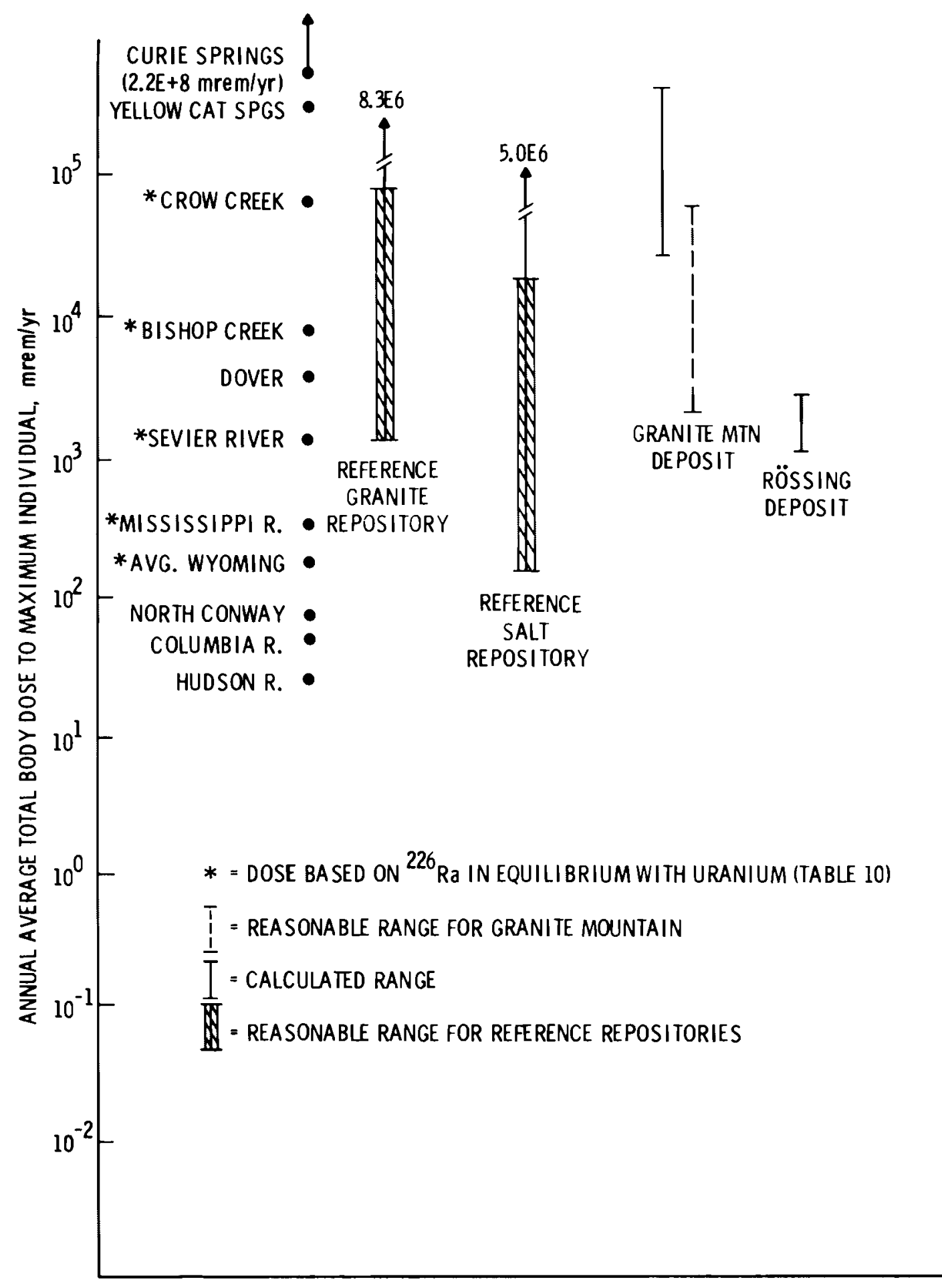

FIGURE 17. Summary of Calculated Potential Radiological Consequences: Average, Annual, Total-Body Dose, Well Scenario 


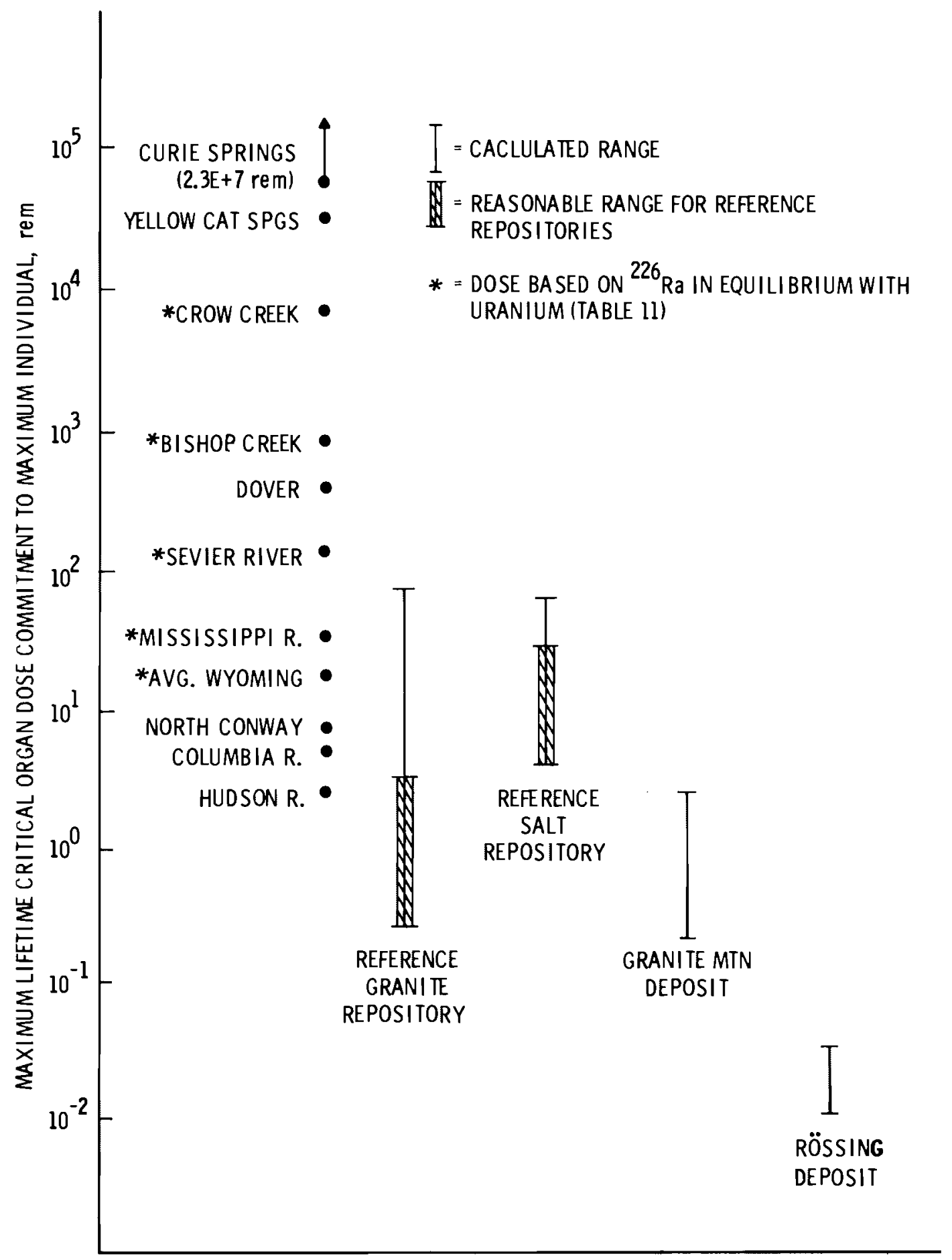

FIGURE 18. Summary of Calculated Potential Radiological Consequences: Lifetime Critical-Organ Dose Commitment, General Scenario 


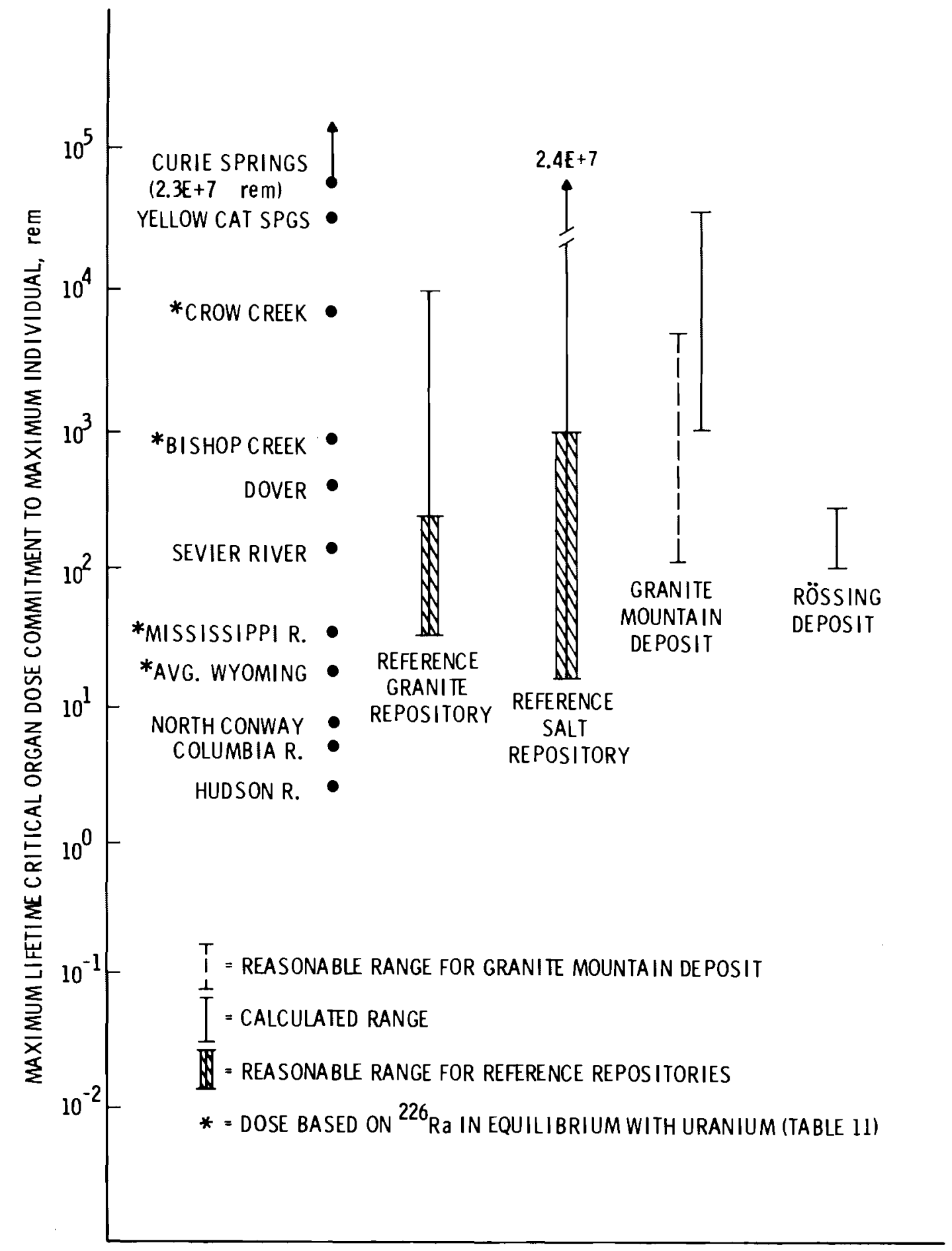

IIGURE 19. Summary of Calculated Potential Radiological Consequences: Lifetime Critical-Organ Dose Commitment, Well Scenario 
Figures 16 through 19 show a comparison among the measured radionuclide concentrations in U.S. waters, the calculated potential releases from two large ore deposits, and potential releases from the two reference repositories in four different, but related ways.

Figure 16 shows the results in terms of the average, annual, total-body dose for the general scenario. Figure 17 shows the results in terms of average, annual, total-body dose from the intrusion water well scenario (reference Figure 15), resulting in much higher doses from the repositories and ore deposits since the water is used by the maximum individual prior to dilution into surface waters.

Figure 18 show's the results in terms of maximum lifetime critical-organ dose commitment for the general scenario, and Figure 19 shows the results for 1 ifetime critical-organ dose due to the water well scenario. The critical organ is the organ that receives the greatest cumulative dose commitment (rem), regardless of any arbitrary allowable dose limit differences among the various organs. For all of the dose consequences (Table 11) calculated from the reported nuclide concentrations in U.S. waters (Table 7), the critical organ was bone. Bone was also the critical organ for both the ore deposits and the principle critical organ for the reference repositories. Under some of the more extreme conditions, the critical organs for the repositories were the thyroid $\left({ }^{129}\right.$ I) and gastrointestinal tract including the lower large instestine $\left({ }^{99} \mathrm{TC}\right)$, and again bone $\left({ }^{14} \mathrm{C},{ }^{90} \mathrm{Sr}\right)$.

In nearly all cases (Figures 16 through 19), the peak radionuclide releases occur over such long periods of time, thousands to even millions of years, that they can be considered chronic, constant environmental conditions. One exception is the case of the most severe condition of the well scenario for the reference salt repository (see Figures 17 and 19) where the dose was dominated by ${ }^{90} \mathrm{Sr}$, a short-lived isotope of extreme dose significance. In the cases where ${ }^{90} \mathrm{Sr}$ dominates the dose, the release was 1 imited to a maximum of 300 years.

The ${ }^{90} \mathrm{Sr}$ doses are high in the reference salt and granite site studies (Cloninger, Cole and Washburn 1980 and Cloninger and Cole 1980), because the 
authors attempted to push the limits of the repository system to the point where engineered barriers to a release would become absolutely necessary in order to provide reasonable safety. In order to attain such high biosphere releases and the resultant high dose, the natural barriers to a high release rate--such as solubility limits, reasonable ground water velocities, and reasonable transport distances--had to be ignored singly and serially. While the upper limits from the most severe scenarios are indicated on Figures 16 through 19, the reasonable range is also shown (shaded bars) and is the proper basis for the comparison. A reasonable upper limit for the repositories in terms of representative parameters was taken to be a release rate of nuclides into the ground water of no more than $10^{-3} / \mathrm{yr}$ (fractional) and a ground-water travel time from the repository to surface waters of no less than 500 years and to a water well borehole of no less than 100 years (a 500-year minimum was used here for the ore deposit calculations). This 100-year minimum still allows penetration of the well borehole within $30 \mathrm{~m}$ of either repository.

The geologic transport model was particularly conservative for the water well scenario since it treats the repository and ore deposit as a point source in the flow field. Its application to the Granite Mountain deposit was extremely conservative due to the immense dimensions of the deposit compared to the transport distance to the well borehole. These results would not be at all valid for Granite Mountain, except that the low release rate $\left(1.3 \times 10^{-7}\right.$ to $1.3 \times 10^{-8} / \mathrm{yr}$, fractional), rather than the far-field hydrology, controls the Granite Mountain dose consequences. Therefore, relative to the other calculations on Figures 17 and 19, a more reasonable range of consequences from the well scenario for Granite Mountain is shown by the dashed bar.

The total body dose from the ore deposits and for most of the parameter range of the repositories is dominated by ${ }^{226} \mathrm{Ra}$ created from uranium parents. Included in this dose is the direct dose from ${ }^{226} \mathrm{Ra}$ and its daughters $\left({ }^{226} \mathrm{Ra}+\right.$ D), which includes the dose from ${ }^{210} \mathrm{~Pb}$ and $210_{\mathrm{Po}}$ created by decay after ingestion of ${ }^{226} \mathrm{Ra}$ plus additional dose from ${ }^{210} \mathrm{~Pb}$ and $210_{\mathrm{Po}}$ released to the biosphere in decay equilibrium with ${ }^{226} \mathrm{Ra}$ and subsequently ingested. The uranium itself contributes a minor fraction of the total dose. However, under some conditions for the reference granite repository, ${ }^{234} \mathrm{U}$ plus ${ }^{237} \mathrm{~Np}$ from its 
original inventory and from its precursor ${ }^{241}$ Am contribute significantly to the total body dose and can dominate the critical-organ dose. For very extreme release rates of nuclides into the ground water, ${ }^{14} \mathrm{C},{ }^{99} \mathrm{TC}$ and ${ }^{129} \mathrm{I}$ can dominate both the total-body and critical-organ dose from both the repositories. As previously mentioned, if this extreme release rate is combined with high ground-water velocity and a short pathlength to a water well (includes no credit for the waste container) and the flowing ground water contacts the waste immediately after the repository is sealed, the dose is dominated entirely by ${ }^{90} \mathrm{Sr}$.

\section{Discussion of the Results}

In Figure 16, the calculated potential dose to a maximum individual from the reference repositories ranges from a high of about $240 \mathrm{mrem} / \mathrm{yr}$ to a low of about $0.10 \mathrm{mrem} / \mathrm{yr}$ resulting from the general scenario. This compares with a calculated dose that ranges from 23 to $2 \mathrm{mrem} / \mathrm{yr}$ for the Granite Mountain deposit and from 0.2 to $0.1 \mathrm{mrem} / \mathrm{yr}$ for the Rossing deposit.

With the exception of the upper bounds of potential consequences from the reference salt repository, the results from the repositories are in the same general range as those from the ore deposits. If the waste package release rates for the repositories are less than $10^{-4} / \mathrm{yr}$ (fractional) or if the ${ }^{14} \mathrm{C}$, ${ }^{99} \mathrm{TC}$ and ${ }^{129}$ I are eliminated from the repository-bound waste, the upper limits for the repositories would be the same as for the Granite Mountain deposit (about $20 \mathrm{mrem} / \mathrm{yr}$ ). Note that in Figure 16, most of the points representing the water sources whose nuclide concentrations were measured lie above the range calculated for both reference repositories and both ore deposits.

To explain the relative positions, two reasons are given other than the uncertainties regarding scenarios and the geologic transport calculations. First, these measured values represent resultant consequences from quite a range of actual yet unknown scenarios in terms of release rate from the ore, size and quality of the ore deposit, ground-water velocity, and proximity of the deposit to the discharge point where the measurement was made. Second, many of the measured values probably represent waters whose radionuclide content is not from a single source, as were the calculations for the repositories and ore deposits, but from several in addition to the minerals from the immediate area where the samples were taken. 
As might be expected, the dose consequences from the intrusion water well scenario, summarized in Figure 17, are considerably higher for both repositories and both ore deposits, and they generally lie in the higher range of the measured values. Furthermore, the reference repositories and the ore deposits are even more similar in potential consequences from the well scenario than from the general scenario summarized in Figure 16. It is interesting to note that even under the most severe conditions imaginable (but not necessarily reasonable) for this scenario, the maximum consequences from the repositories are at least an order of magnitude less than that calculated from the reported radium concentration of Curie Springs (top of Figure 17 and Table 10).

This is probably a useful place to point out that the extremely high doses for the repositories, ore deposits, and the conversions of reported nuclide concentrations in U.S. waters from Table 7 that are reported here are based on linear extrapolation from dose transfer factors that were determined at much lower dose rates. Thus, the actual upper limits for the well scenario consequences from the reference repositories and the ore deposits as well as those for extremely high reported concentrations of ${ }^{226} \mathrm{Ra}$ (Crow Creek, Yellow Cat Springs, and Curie Springs) would, in reality, be somewhat lower; however, relative to one another, they would still be about the same.

Figures 18 and 19 present the comparison of consequences on a slightly different basis, the lifetime critical-organ dose commitment to the maximum individual. In Figure 18, as in Figure 16, the results are shown for the general scenario and the resultant consequences for the repositories, and the ore deposits are again at the lower range of the measured values. On the basis of critical-organ dose, however, the calculated potential consequences from the repositories run generally higher than those from the ore deposits, although the reasonable range for the reference granite repository is essentially identical to the result for the Granite Mountain deposit.

The critical-organ dose consequences for the well scenario are shown in Figure 19. The calculated results for the repositories and ore deposits span the range of reported U.S. waters nuclide content. Within the predictive accuracy of the methodology and models, the reasonable ranges for the repositories, Granite Mountain, and the Rossing deposit are equivalent. 
It may well be said of man in the 20th century that he spent most of his creative genius in trying to dispose of his own wastes. 



\section{REFERENCES}

Arnold, E. C., and J. M. Hi11. 1980. "New Mexico's Energy Resources '79." New Mexico Bureau of Mines and Mineral Resources Circular 172, p. 45. Socorro, New Mexico.

Barker, F. B., and R. C. Scott. 1958. "Uranium and Radium in the Ground Water of the Llano Estecado, Texas and New Mexico." Transactions of the American Geophysical Union 39(3):459-468.

Barnes, C. H., L. Geller and D. R. Hi11. 1977. Uranium Data. EA-400, p. 5-2. Prepared by S. M. Stoller Corp. for the Electric Power Research Institute, Palo Alto, California.

Benedict, M., and T. H. Pigford. 1957. Nuclear Chemical Engineering. McGraw-Hi11, New York.

Brobst, D. A., and W. P. Pratt, eds. 1973. U.S. Mineral Resources Geological Survey Professional Paper. No. 820, p. 22.

Burkholder, H. C., and M. 0. Cloninger. 1978. "The Reconcentration Phenomenon of Radionuclide Chain Migration." American Institute of Chemical Engineers Symposium Series 74(179).

Burkholder, H. C. et al. 1976. "Incentives for Partitioning High-Level Waste." Nuclear Technology 31:202. Also as BNWL-1927, Pacific Northwest Laboratory, Richland, Washington, 1975.

Cathcart, J. B. 1956. "Distribution and Occurrence of Uranium in the Calcium Phosphate Zone of the Land Pebble Phosphate District of Florida." In Proceedings of International Conference on the Peaceful Uses of Atomic Energy, Vol. 6, p. 515. United Nations, New York.

Chervet, J., and R. Coulomb. 1958. "Geochemical Behavior of Uranium in the Alteration Cycle." In Proceedings of the Second U.N. Conference on the Peaceful Uses of Atomic Energy, V01. 2, p. 199-203. United Nations, New York.

Cloninger, M. 0., and C. R. Cole. 1980. An Analysis of the Use of Engineered Barriers for Isolation of Spent Fuel in Three Reference Geologies. PNL-3530, Pacific Northwest Laboratory, Richland, Washington.

Cloninger, M. 0., C.R. Cole and J.F. Washburn. 1980. An Analysis of the Use of Engineered Barriers for Geologic Isolation of Spent Fuel in Reference Salt Site Repository. PNL-3356, Pacific Northwest Laboratory, Richland, Washington.

Davis, S. N., and R. J. M. DeWiest. 1966. Hydrogeology. pp. 134-136. John Wiley and Sons, New York. 
Dayton, S. 1978. "Uranium." Engineering and Mining Journal. 179(11):73-137.

Deffeyes, K., and I. Macgregor. 1978. "Uranium Distribution in Mined Deposits and in the Earth's Crust." Open File Report GJBX-1, pp. 14-15. U.S. Department of Energy, Grand Junction Office, Grand Junction, Colorado.

DeMier, W. V., et al. 1979. GETOUT--A Computer Program for Predicting Radionuclide Decay Chain Transport Through Geologic Media. PNL-2970, Pacific Northwest Laboratory, Richland, Washington.

Denson, N. M., and J. R. Gi11. 1965. "Uranium Bearing Lignite and Carbonaceous Shale in the Southwestern Part of the Williston Basin--A Region Study." U.S. Geological Survey Professional Paper 463, pp. 55, 58, Washington, DC.

Fehm, U., L. M. Cathles and H. D. Holland. 1978. "Hydrothermal Convection and Uranium Deposits in Abnormally Radioactive Plutons." Economic Geology 73:1556-1566.

Finch, W. I. 1967. "Geology of Epigenetic Uranium Deposits in Sandstone in the United States." U.S. Geological Survey Professional Paper 538, p. 2, lashington, DC.

Fix, P. F. 1956. Geochemical Prospecting for Uranium by Sampling Ground and Surface Waters. In Proceedings of International Conference on the Peaceful Uses of Atomic Energy, Vol. 6, p. 788. United Nations, New York.

Gabelmayer, J. W. 1970. "Speculation on the Uranium Ore Fluid, Uranium Exploration Geology." IAEA, Vienna, Austria.

Golabi, K., and A. Lamont. 1978. "Study to Integrate NURE Data" HoodwardClyde Consultants. Open File Report G.JBX-25-170. U.S. Department of Energy, Grand Junction Office, Grand Junction, Colorado.

Harshmann, E. N. 1968. "Uranium Deposits of the Shirley Basin, Wyoming." In Ore Deposits of the United States 1933-1967, pp. 85?-855. American Institute of Min. Met. and Petroleum Engineers, New York.

Hilpert, L. S. 1969. "Uranium Resources of Northwestern New Mexico." U.S. Geological Survey Professional Paper 603, p. 3, Washington, DC.

Hiss, William L. 1977. "Uranium Mine Waste Water--A Potential Source of Ground Water in Northwestern New Mexico." Supplement to New Mexico Geol. Soc. Guidebook, 28th Field Conf., San Juan Basin III, Socorro, New Mexico.

Houston, J. R., and P. J. Blumer. 1979. Environmental Surveillance at Hanford for Calendar Year 1978. PNL-2932, Pacific Northwest Laboratory, Richland, Washington.

Illsley, C. T. 1957. "Evaluation of Hydrogeochemical Techniques in the Mt. Spokane Area, Washington." RME-1098. 
Judson, S., and J. K. Osmond. 1955. "Radioactivity in Ground and Surface Water." American Journal of Science 253:104-116.

Kaufman, R. F., G. C. Eadie and C. P. Russel1. 1975. "Water Quality Impacts of Uranium Mining and Milling Activities in the Grants Mineral Belt, New Mexico", Technical Note ORP/LV 75-4 PB-251-470 National Technical Information Service, Springfield, Virginia.

Kelley, V. C. 1963. "Geology and Technology of the Grants Uranium Region." Memoir 15, New Mexico Bureau of Mines and Mineral Resources, p. 83, Socorro, New Mexico.

Langmuir, D. 1978. "Uranium-Solution-Mineral Equilibria at Low Temperatures with Applications to Sedimentary Ore Deposits," Geochimica et Cosmochimica Acta, 42:547-569.

Larsen, E. S., Jr. et al. 1958. "Distribution of Uranium in Volcanic Rocks of the San Juan Mountains." In Proceedings of the Second U.N. Conference on the Peaceful Uses of Atomic Energy, Vol. 2, p. 513. United Nations, New York.

Love, J. D. 1970. "Cenozoic Geology of the Granite llountains Area, Central Wyoming." U.S. Geological Survey Professional Paper 495-C, Washington, DC.

Mape1, 4. J. 1956. "Uraniferous Black Shales in the Northern Rocky Mountains and Great Plains Regions." In Proceedings of the International Conference on the Peaceful Uses of Atomic Energy, Vol. 6, p. 450. United Nations, New Yorl..

Mckelvey, V. E., and Carswell, L. D. 1956. "Uranium in the Phosphoria Formation." In Proceedings of the International Conference on the Peaceful Uses of Atomic Energy, Vol. 6, p. 505. United Nations, Hew York.

Murphy, J. F. 1956. "Uranium Bearing Water in the Crow Creek and Muskrat Creek Areas, Fremont County, Wyoming." USGS Report of Investigation, No. 5. Washington, DC.

Muzor, E. 1976. "Multiracing and Multisamples in Hydrological Studies." Intrepretation of Environmental I sotope and Hydrochemical Data in Ground-Water Hydrology. IAEA. Vienna, Austria.

Napier, B. A., W. E. Kennedy, Jr. and J. K. Soldat. 1980. PABLM--A Computer Program for Calculating Accumulated Radiation Doses from Radionuclides in the Environment. PNL-3209, Pacific Northwest Laboratory, Richland, Washington.

Rennerfelt, J. 1977. Composition of Ground Water of Great Depth in Granitic Bedrock. KBS Technical Report No. 36, Orrje a Co., Scandiaconsult, Stockholm, Sweeden. 
Rohrmann, C. A. 1969. Chart of the Nuclides. Battelle Pacific Northwest Laboratories, Richland, Washington.

Rona, E., and W. D. Urry. 1952. "Radioactivity of Ocean Sediments." VII Radium and Uranium Content of Ocean and River Waters. American Journal of Science 250:241-262.

Rose, A. W., M. L. Keith and N. H. Suhr. 1976. Geochemical Drainage Survey for Uranium: Sampling and Analytical Methods Based on Trial Surveys in Pennsylvania. GJ0-1645-1. U.S. Department of Energy, Grand Junction Office, Grand Junction, Colorado.

Rosholt, J. N., and A. J. Bartel. 1969. "Uranium, Thorium, and Lead "Systematics in Granite Mountains Wyoming." Earth and Planetary Science Letters $7: 141$.

Scott, R. C., and F. B. Barker. 1962. "Data on Uranium and Radium in Ground Water in the United States, 1954-1957." U.S. Geological Survey Professional Paper 426. Washington, DC.

Serne, R. J., Chairman. 1977. In Proceedings of the Task 4 Contractor Information Meetings, Waste Isolation Safety Assessment Program. PNL-SA-6957. Pacific Northwest Laboratory, Richland, Washington.

Smith, B. M. et al. 1961. "National Radioactivity in Ground Water Supplies in Maine and New Hampshire." Journal of the American Water Workers Assoc., p. 75 .

Spaulding, R. F., and W. M. Sackett. 1972. "Uranium Run-Off from the Gulf of Mexico Distributive Province, Anomalous Concentrations." Science $175: 629-631$.

Stuckley, J. S. et al. 1977. "Geochemical and Petrological Studies of Uranium Granite from the Granite Mountains Wyoming." J. Research U.S. Geological Survey 5:61.

Swanson, V. E. 1956. "Uranium in Marine Black Shales of the United States." In Proceedings of the International Conference on the Peaceful Uses of Atomic Energy, Vol. 6, p. 431. United Nations, New York.

U.S. Department of Energy. 1978. Statistical Data of the Uranium Industry. GJ0-100(78), p. 16. Grand Junction Office, Grand Junction, Colorado.

U.S. Department of Energy. 1979. Draft Environmental Impact Statement: Management of Commercially Generated Radioactive Waste. DOE/EIS-0046-D. National Technical Information Society, Springfield, Virginia.

Weast, R. C., ed. 1974. Handbook of Chemistry and Physics. 55th ed. CRC Press, Cleveland, Ohio. 
Wedepohl, K. H. 1969. Handbook of Geochemistry, p. 92-I-1, Springer-Verlaz, Berlin, Germany. 

APPENDIX 

TABLE A.1. Repository Nuclide Inventories (curies) at Various Times after Closure in Year 2050

\begin{tabular}{|c|c|c|c|c|c|c|c|c|c|c|}
\hline Isotope & $\underline{1.00+000}$ & $\frac{100}{1.00+002}$ & $\frac{300}{3.00+002}$ & $\frac{1000}{1.00+003}$ & $\begin{array}{l}\text { Time (1 } \\
3000 \\
3.00+003 \\
\end{array}$ & $\begin{array}{l}\text { ars) } \\
\frac{10,000}{1.00+004}\end{array}$ & $\frac{30,000}{3.00+004}$ & $\frac{100,000}{1.00+005}$ & $\frac{300,000}{3.00+005}$ & $\frac{1,000,000}{1.00+006}$ \\
\hline $\begin{array}{l}3_{\mathrm{H}} \\
99_{\mathrm{TC}}\end{array}$ & $\begin{array}{l}4.38+006 \\
9.64+005\end{array}$ & $\begin{array}{l}1.57+004 \\
9.64+005\end{array}$ & $\begin{array}{l}7.22-004 \\
9.62+005\end{array}$ & $\begin{array}{l}1.53-018 \\
9.60+005\end{array}$ & $\begin{array}{l}0.00 \\
9.54+005\end{array}$ & $\begin{array}{l}0.00 \\
9.32+005\end{array}$ & $\begin{array}{l}0.00 \\
8.72+005\end{array}$ & $\begin{array}{l}0.00 \\
6.92+005\end{array}$ & $\begin{array}{l}0.00 \\
3.58+005\end{array}$ & $\begin{array}{l}0.00 \\
3.56+004\end{array}$ \\
\hline${ }^{129} \mathrm{I}$ & $2.48+003$ & $2.48+003$ & $2.48+003$ & $2.48+003$ & $2.48+003$ & $2.46+003$ & $2.46+003$ & $2.46+003$ & $2.44+003$ & $2.38+003$ \\
\hline $\begin{array}{l}14 \mathrm{C} \\
93 \mathrm{Mo} \\
41 \mathrm{Ca} \\
79 \mathrm{Se}\end{array}$ & $\begin{array}{l}2.50+004 \\
0.00 \\
0.00 \\
2.62+004\end{array}$ & $\begin{array}{l}2.46+004 \\
0.00 \\
0.00 \\
2.62+004\end{array}$ & $\begin{array}{l}2.38+004 \\
0.00 \\
0.00 \\
2.62+004\end{array}$ & $\begin{array}{l}2.22+004 \\
0.00 \\
0.00 \\
2.60+004\end{array}$ & $\begin{array}{l}1.74+004 \\
0.00 \\
0.00 \\
2.54+004\end{array}$ & $\begin{array}{l}7.46+003 \\
0.00 \\
0.00 \\
2.36+004\end{array}$ & $\begin{array}{l}6.64+002 \\
0.00 \\
0.00 \\
1.90+004\end{array}$ & $\begin{array}{l}1.40-001 \\
0.00 \\
0.00 \\
9.04+003\end{array}$ & $\begin{array}{l}4.44-012 \\
0.00 \\
0.00 \\
1.07+003\end{array}$ & $\begin{array}{l}0.00 \\
0.00 \\
0.00 \\
6.18-001\end{array}$ \\
\hline $\begin{array}{l}90 \mathrm{Sr} \\
10 \mathrm{Be} \\
60 \mathrm{Co} \\
59 \mathrm{Ni}\end{array}$ & $\begin{array}{l}2.02+009 \\
0.00 \\
8.34+005 \\
2.30+005\end{array}$ & $\begin{array}{l}1.71+008 \\
0.00 \\
1.59+001 \\
2.30+005\end{array}$ & $\begin{array}{l}1.05+005 \\
0.00 \\
1.11-016 \\
2.28+005\end{array}$ & $\begin{array}{l}3.96-002 \\
0.00 \\
0.00 \\
2.28+005\end{array}$ & $\begin{array}{l}1.53-023 \\
0.00 \\
0.00 \\
2.24+005\end{array}$ & $\begin{array}{l}0.00 \\
0.00 \\
0.00 \\
2.10+005\end{array}$ & $\begin{array}{l}0.00 \\
0.00 \\
0.00 \\
1.77+005\end{array}$ & $\begin{array}{l}0.00 \\
0.00 \\
0.00 \\
9.66+004\end{array}$ & $\begin{array}{l}0.00 \\
0.00 \\
0.00 \\
1.71+004\end{array}$ & $\begin{array}{l}0.00 \\
0.00 \\
0.00 \\
3.98+001\end{array}$ \\
\hline $\begin{array}{l}63 \mathrm{Ni} \\
87_{\mathrm{Rb}}\end{array}$ & $\begin{array}{l}2.72+007 \\
1.29+000\end{array}$ & $\begin{array}{l}1.28+007 \\
1.29+000\end{array}$ & $\begin{array}{l}1.34+006 \\
1.29+000\end{array}$ & $\begin{array}{l}1.47+004 \\
1.29+000\end{array}$ & $\begin{array}{l}4.22-003 \\
1.29+000\end{array}$ & $\begin{array}{l}5.46-026 \\
1.29+000\end{array}$ & $\begin{array}{l}0.00 \\
1.29+000\end{array}$ & $\begin{array}{l}0.00 \\
1.29+000\end{array}$ & $\begin{array}{l}0.00 \\
1.29+000\end{array}$ & $\begin{array}{l}0.00 \\
1.29+000\end{array}$ \\
\hline${ }^{135} \mathrm{Cs}$ & $2.00+004$ & $2.00+004$ & $2.00+004$ & $2.00+004$ & $2.00+004$ & $2.00+004$ & $1.99+004$ & $1.96+004$ & $1.87+004$ & $1.59+004$ \\
\hline $\begin{array}{l}137 \mathrm{Cs} \\
107 \mathrm{Po}\end{array}$ & $\begin{array}{l}2.88+009 \\
7.32+003\end{array}$ & $\begin{array}{l}2.86+008 \\
7.32+003\end{array}$ & $\begin{array}{l}2.80+005 \\
7.32+003\end{array}$ & $\begin{array}{l}2.70-001 \\
7.32+003\end{array}$ & $\begin{array}{l}2.38-021 \\
7.32+003\end{array}$ & $\begin{array}{l}0.00 \\
7.32+003\end{array}$ & $\begin{array}{l}0.00 \\
7.30+003\end{array}$ & $\begin{array}{l}0.00 \\
7.26+003\end{array}$ & $\begin{array}{l}0.00 \\
7.10+003\end{array}$ & $\begin{array}{l}0.00 \\
6.64+003\end{array}$ \\
\hline $126 \mathrm{Sn}$ & $3.54+004$ & $3.54+004$ & $3.54+004$ & $3.52+004$ & $3.48+004$ & $3.32+004$ & $2.88+004$ & $1.63+004$ & $4.44+003$ & $3.50+001$ \\
\hline $\begin{array}{l}151 \mathrm{Sm} \\
166 \mathrm{mHO}_{\mathrm{O}} \\
152 \mathrm{Eu} \\
154 \mathrm{Eu} \\
93 \mathrm{Zr}\end{array}$ & $\begin{array}{l}6.36+007 \\
0.00 \\
1.33+005 \\
9.02+007 \\
1.24+005\end{array}$ & $\begin{array}{l}2.86+007 \\
0.00 \\
4.14+002 \\
1.19+006 \\
1.24+005\end{array}$ & $\begin{array}{l}2.62+006 \\
0.00 \\
1.25-005 \\
2.72+000 \\
1.24+005\end{array}$ & $\begin{array}{l}2.22+004 \\
0.00 \\
1.14-020 \\
1.42-011 \\
1.24+005\end{array}$ & $\begin{array}{l}2.68+003 \\
0.00 \\
0.00 \\
0.00 \\
1.24+005\end{array}$ & $\begin{array}{l}1.68-027 \\
0.00 \\
0.00 \\
0.00 \\
1.24+005\end{array}$ & $\begin{array}{l}0.00 \\
0.00 \\
0.00 \\
0.00 \\
1.23+005\end{array}$ & $\begin{array}{l}0.00 \\
0.00 \\
0.00 \\
0.00 \\
1.19+005\end{array}$ & $\begin{array}{l}0.00 \\
0.00 \\
0.00 \\
0.00 \\
1.08+005\end{array}$ & $\begin{array}{l}0.00 \\
0.00 \\
0.00 \\
0.00 \\
7.84+004\end{array}$ \\
\hline $\begin{array}{l}113 \mathrm{mc} \mathrm{d} \\
248 \mathrm{Cm} \\
244 \mathrm{Pu} \\
244 \mathrm{Cm} \\
240 \mathrm{Pu} \\
236 \mathrm{U}\end{array}$ & $\begin{array}{l}1.10+005 \\
0.00 \\
0.00 \\
2.38+007 \\
3.38+007 \\
1.69+004\end{array}$ & $\begin{array}{l}7.84+002 \\
0.00 \\
0.00 \\
5.18+005 \\
3.34+007 \\
1.70+004\end{array}$ & $\begin{array}{l}2.80-004 \\
0.00 \\
0.00 \\
5.30+000 \\
3.24+007 \\
1.73+004\end{array}$ & $\begin{array}{l}3.58-017 \\
0.00 \\
0.00 \\
0.00 \\
3.04+007 \\
1.78+004\end{array}$ & $\begin{array}{l}0.00 \\
0.00 \\
0.00 \\
0.00 \\
2.48+007 \\
1.88+004\end{array}$ & $\begin{array}{l}0.00 \\
0.00 \\
0.00 \\
0.00 \\
1.21+007 \\
2.30+004\end{array}$ & $\begin{array}{l}0.00 \\
0.00 \\
0.00 \\
0.00 \\
1.56+006 \\
2.46+004\end{array}$ & $\begin{array}{l}0.00 \\
0.00 \\
0.00 \\
0.00 \\
1.19+003 \\
2.64+004\end{array}$ & $\begin{array}{l}0.00 \\
0.00 \\
0.00 \\
0.00 \\
1.47-006 \\
2.62+004\end{array}$ & $\begin{array}{l}0.00 \\
0.00 \\
0.00 \\
0.00 \\
0.00 \\
2.58+004\end{array}$ \\
\hline${ }^{232} \mathrm{Th}$ & $2.04-005$ & $8.66-005$ & $3.16-004$ & $1.30-003$ & $1.99-003$ & $1.01-002$ & $7.30-002$ & $1.88-001$ & $2.84-001$ & $1.27+000$ \\
\hline
\end{tabular}


TABLE A.1. (Contd)

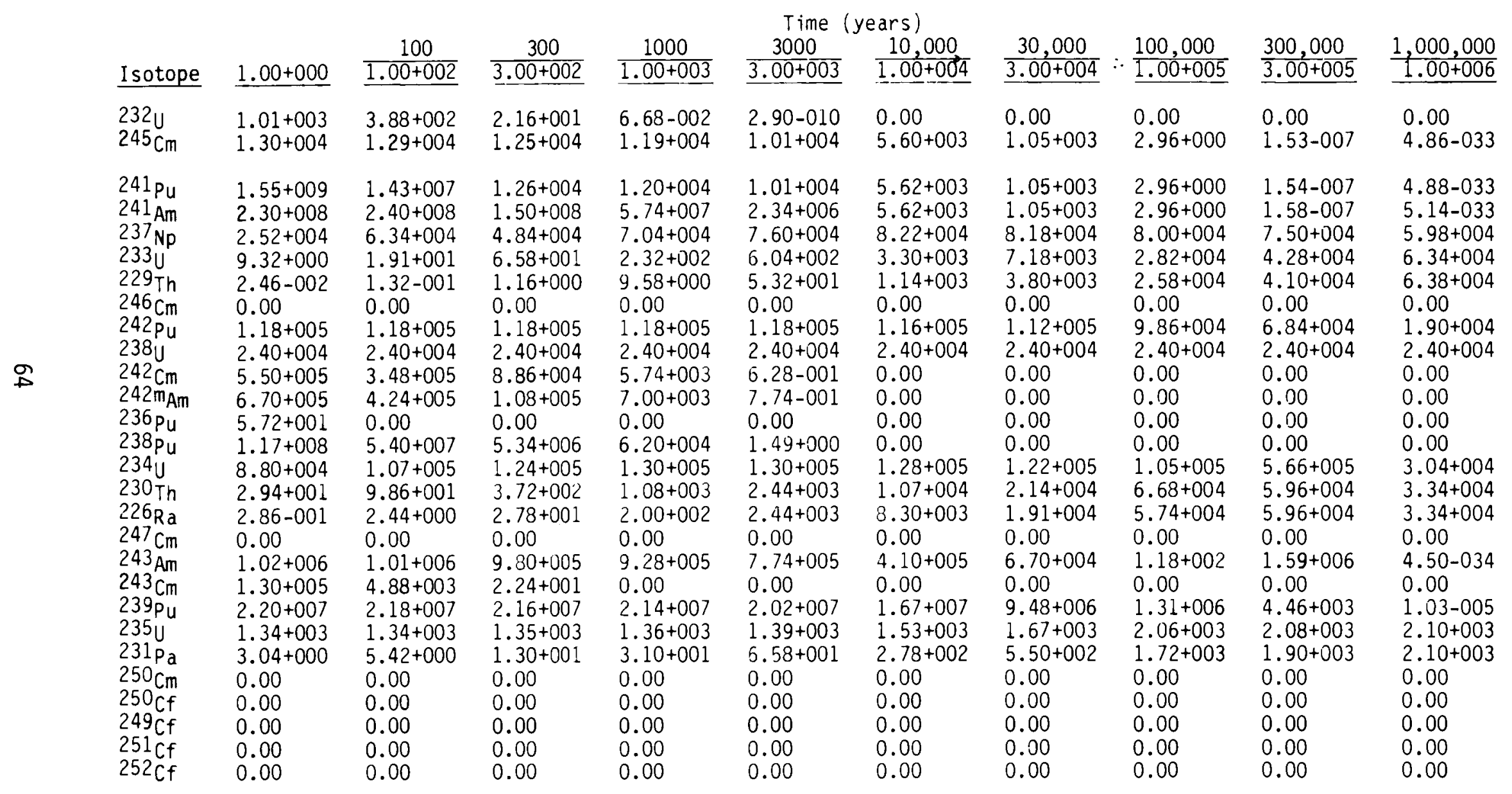




\section{TABLE A.2. Natural Distribution of Uranium}

\begin{tabular}{|c|c|c|c|c|}
\hline Geological Unit & $\begin{array}{c}\text { Mass } \\
\text { (Whole Earth) } \\
\left(\times 10^{25} \mathrm{gm}\right) \\
\end{array}$ & $\begin{array}{c}\text { Conc. U } \\
\text { ppm }\end{array}$ & $\begin{array}{c}\text { Mass-U } \\
(\text { Whole Earth) } \\
\left(\times \quad 10^{9} \text { tonne } U\right)\end{array}$ & $\begin{array}{r}\text { Mass }-U \\
\text { Cont. U.S.A. } \\
\left(\times 10^{9} \text { tonne U) }\right. \\
\end{array}$ \\
\hline $\begin{array}{l}\text { WHOLE EARTH } \\
\text { CORE } \\
\text { MANTLE } \\
\text { CRUST }\end{array}$ & $\begin{array}{l}597.6 \\
193.6 \\
401.6 \\
2.57\end{array}$ & $\begin{array}{l}0.0105 \\
0.00001 \\
0.005 \\
1.67\end{array}$ & $\begin{array}{r}63,000.00 \\
20.00 \\
20,000.00 \\
43,000.00\end{array}$ & \\
\hline $\begin{array}{l}\text { Continental Crust } \\
\text { Mafic } \\
\text { Sialic }\end{array}$ & $\begin{array}{l}2.09 \\
1.01 \\
0.99\end{array}$ & $\begin{array}{l}1.93 \\
1.45 \\
2.56\end{array}$ & $\begin{array}{l}40,000.00 \\
14,625.00 \\
25,375.00\end{array}$ & $\begin{array}{r}979.975 \\
1,700.16\end{array}$ \\
\hline $\begin{array}{l}\frac{\text { Metamorphic }}{\text { Igneous }} \\
\text { Plutonic } \\
\text { Veins/Pegmatites } \\
\text { Veins/Pegmatites } \\
\text { U-Granites } \\
\text { Granodiorites } \\
\text { Diorite/Gabbro }\end{array}$ & $\begin{array}{l}0.43 \\
0.43 \\
0.1754\end{array}$ & $\begin{array}{c}2.00 \\
1.93 \\
5,000-10,000 \\
10,000 \\
5-15 \\
3.00 \\
1.53\end{array}$ & $\begin{array}{r}0.0013 \\
0.0018 \\
597.00 \\
5,000.00 \\
80.00\end{array}$ & $\begin{array}{c}0.00012 \\
0.000012 \\
40.00 \\
335.00 \\
5.36\end{array}$ \\
\hline $\begin{array}{l}\text { Volcanic } \\
\text { U-Rhyolite } \\
\text { Andesite } \\
\text { Basalt }\end{array}$ & $\begin{array}{l}0.0437 \\
0.0510\end{array}$ & $\begin{array}{r}100-300 \\
2.00 \\
1.00\end{array}$ & $\begin{array}{r}0.104 \\
800.00 \\
4,100.00\end{array}$ & $\begin{array}{r}0.007 \\
53.60 \\
274.70\end{array}$ \\
\hline $\begin{array}{l}\text { Sedimentary } \\
\text { Fold Belts } \\
\text { Sandstones } \\
\text { Shales } \\
\text { Limestones } \\
\text { Volcanogenic } \\
\text { Evaporites }\end{array}$ & $\begin{array}{l}0.128 \\
0.094 \\
0.013 \\
0.037 \\
0.015 \\
0.024 \\
0.0003\end{array}$ & $\begin{array}{l}1.01 \\
4.00 \\
2.2 \\
1.0 \\
0.2\end{array}$ & $\begin{array}{r}3,200.00 \\
2,200.00 \\
180.00 \\
1,500.00 \\
330.00 \\
240.00 \\
5.00\end{array}$ & $\begin{array}{r}12.06 \\
100.59 \\
22.11 \\
16.08 \\
0.40\end{array}$ \\
\hline $\begin{array}{l}\text { Platf orms } \\
\text { U-Sandstones } \\
\\
\text { Sandstones } \\
\text { Placers } \\
\text { Shales } \\
\text { U-Shales } \\
\text { J-Shales } \\
\text { Phosphorites } \\
\text { Limestones } \\
\text { Volcanogenic } \\
\text { Evaporites }\end{array}$ & $\begin{array}{l}0.007 \\
0.001 \\
0.0007\end{array}$ & $\begin{array}{c}600-1,000 \\
1,300-3,000 \\
1.01 \\
1,000-2,000 \\
4.00 \\
10-40 \\
40-200 \\
120-300 \\
2.2 \\
1.0 \\
0.2\end{array}$ & $\begin{array}{c}940.00 \\
0.075 \\
31.00 \\
0.001 \\
680.00 \\
29.10 \\
0.09 \\
1.94 \\
150.00 \\
10.00 \\
14.00\end{array}$ & $\begin{array}{l}0.004 \\
0.0080 \\
5.43 \\
0.00007 \\
45.56 \\
1.95 \\
0.006 \\
0.13 \\
10.05 \\
0.67 \\
0.94\end{array}$ \\
\hline $\begin{array}{l}\text { Oceanic crust } \\
\text { Igneous /Metamorpinic } \\
\text { Sedimentary } \\
\text { Deep Ocean } \\
\text { Calcareous oozes } \\
\text { Siliceous oozes } \\
\text { Ferrugenous Clay } \\
\text { Red clay } \\
\text { Volcanogenic }\end{array}$ & $\begin{array}{l}0.43 \\
0.38 \\
0.1005 \\
0.02 \\
0.008 \\
0.003 \\
0.001 \\
0.006 \\
0.0006\end{array}$ & $\begin{array}{l}0.1 \\
2.0 \\
1.0 \\
0.77 \\
0.45 \\
1.30 \\
3.00 \\
1.00\end{array}$ & $\begin{array}{r}2,600.00 \\
380.00 \\
2,200.00 \\
200.00 \\
60.00 \\
14.00 \\
13.00 \\
180.00 \\
6.00\end{array}$ & \\
\hline $\begin{array}{l}\text { Shallow Ocean } \\
\text { Shelf } \\
\text { Hemipelagic }\end{array}$ & $\begin{array}{l}0.0125 \\
0.068\end{array}$ & $\begin{array}{l}1.92 \\
3.02 \\
2.0\end{array}$ & $\begin{array}{r}1,700.00 \\
380.00 \\
1,400.00\end{array}$ & \\
\hline $\begin{array}{l}\text { Hydrosphere } \\
\text { Rivers/Lakes } \\
\text { Ground water } \\
\text { Oceans } \\
\text { Ice }\end{array}$ & $\begin{array}{l}0.000051 \\
0.00051 \\
0.141 \\
0.0023\end{array}$ & $\begin{array}{l}0.0001 \\
0.0001 \\
0.001 \\
0.0001\end{array}$ & $\begin{array}{l}0.00005 \\
0.0005 \\
14.00 \\
0.0022\end{array}$ & $\begin{array}{l}0.0000335 \\
0.000335\end{array}$ \\
\hline
\end{tabular}


TABLE A.3. Radioactive Decay Products of Natural Uranium

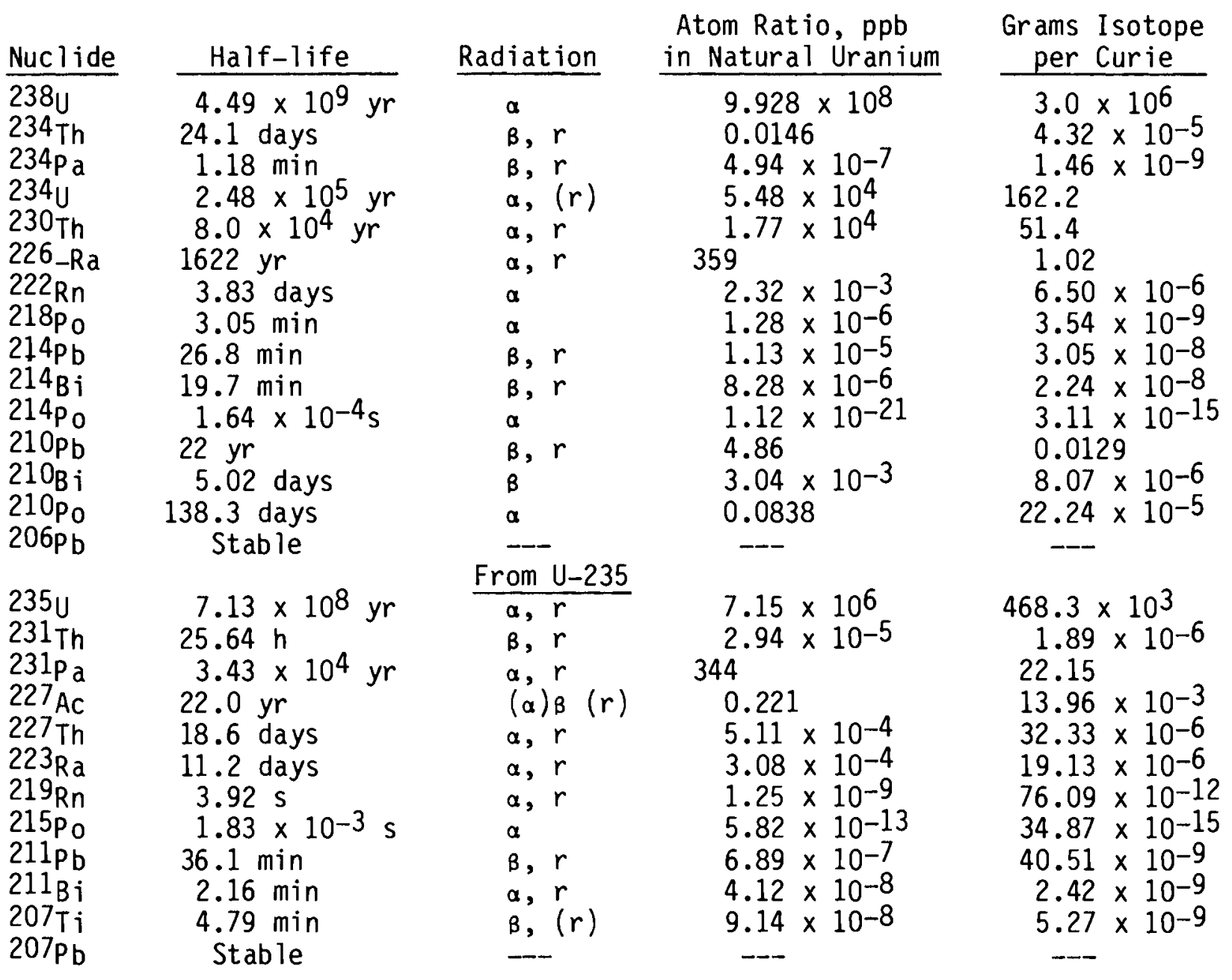

TABLE A.4. Radioactive Decay Products of Natural Thorium

\begin{tabular}{l} 
Nuclide \\
\hline $232 \mathrm{Th}$ \\
$228 \mathrm{Ra}$ \\
$228 \mathrm{Ac}$ \\
$228 \mathrm{Th}$ \\
$224 \mathrm{Ra}$ \\
$220 \mathrm{Rn}$ \\
$216 \mathrm{Ro}$ \\
$212 \mathrm{~Pb}$ \\
$212 \mathrm{Bi}$ \\
$212 \mathrm{Po}(64 \%)$ \\
$208 \mathrm{Ti}(36 \%)$ \\
$208 \mathrm{pb}$
\end{tabular}

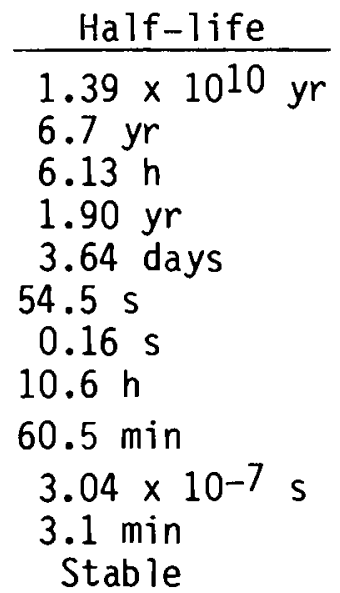

Grams Isotope per Curie

$9.01 \times 10^{6}$

$4.27 \times 10^{-3}$

$4.46 \times 10^{-7}$

$1.21 \times 10^{-3}$

$6.24 \times 10^{-6}$

$1.06 \times 10^{-9}$

$3.02 \times 10^{-12}$

$7.17 \times 10^{-7}$

$6.82 \times 10^{-8}$

$5.71 \times 10^{-18}$

$3.43 \times 10^{-9}$ 


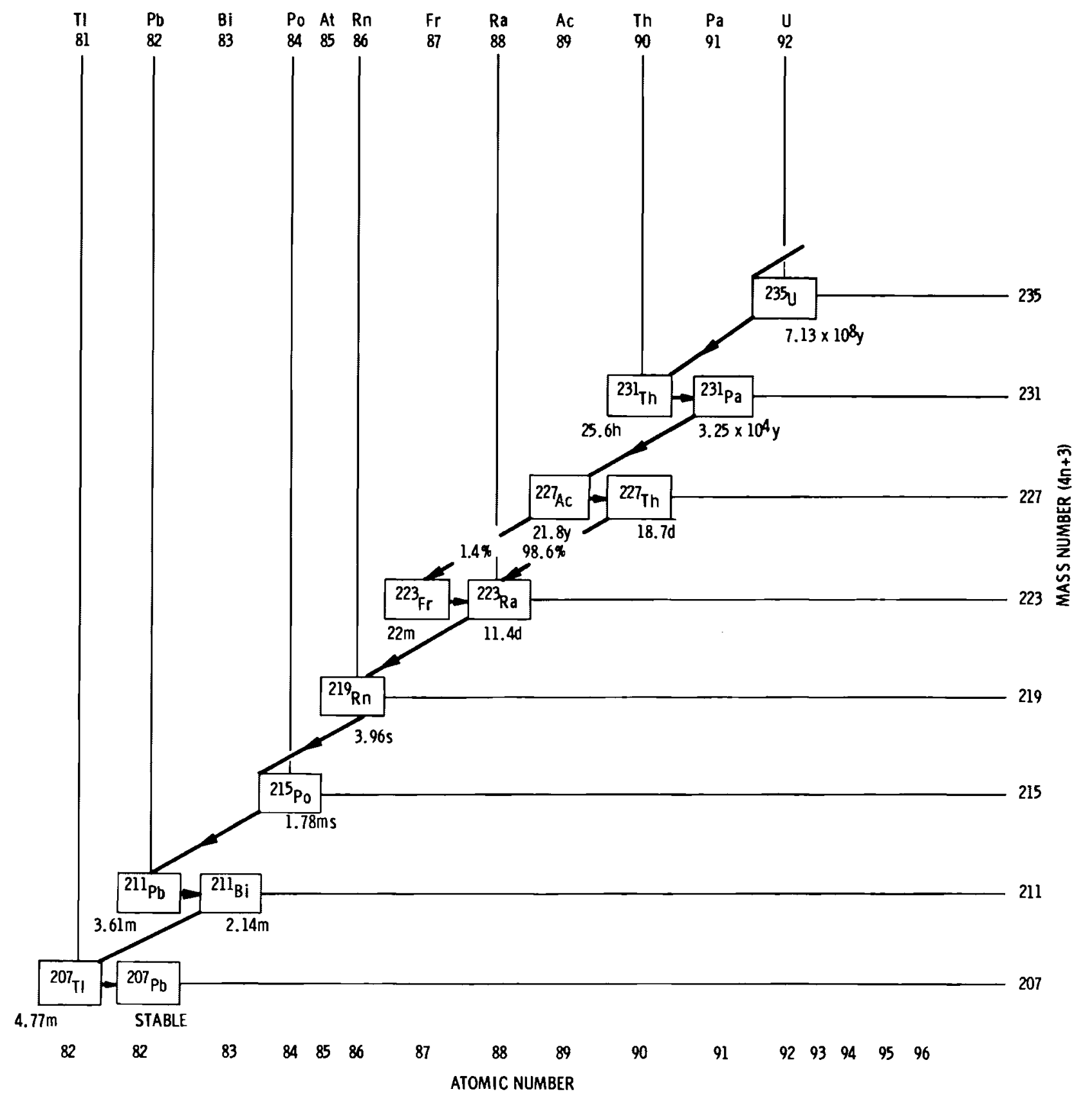

THE SOLID BOXES DENOTE NATURAUY OCCURRING NUCLIDES. ADJACENT NUMBERS INDICATE HALF $Z$ IFE OF ISOTOPE. DIAGONAL ARROWS INDICATE \& AND HORIZONTIAL ARROWS B DECAY. CHAIN BRANCHES OF <1\% OMITED.

FIGURE A.1. Uranium-235 Decay Chain Series 


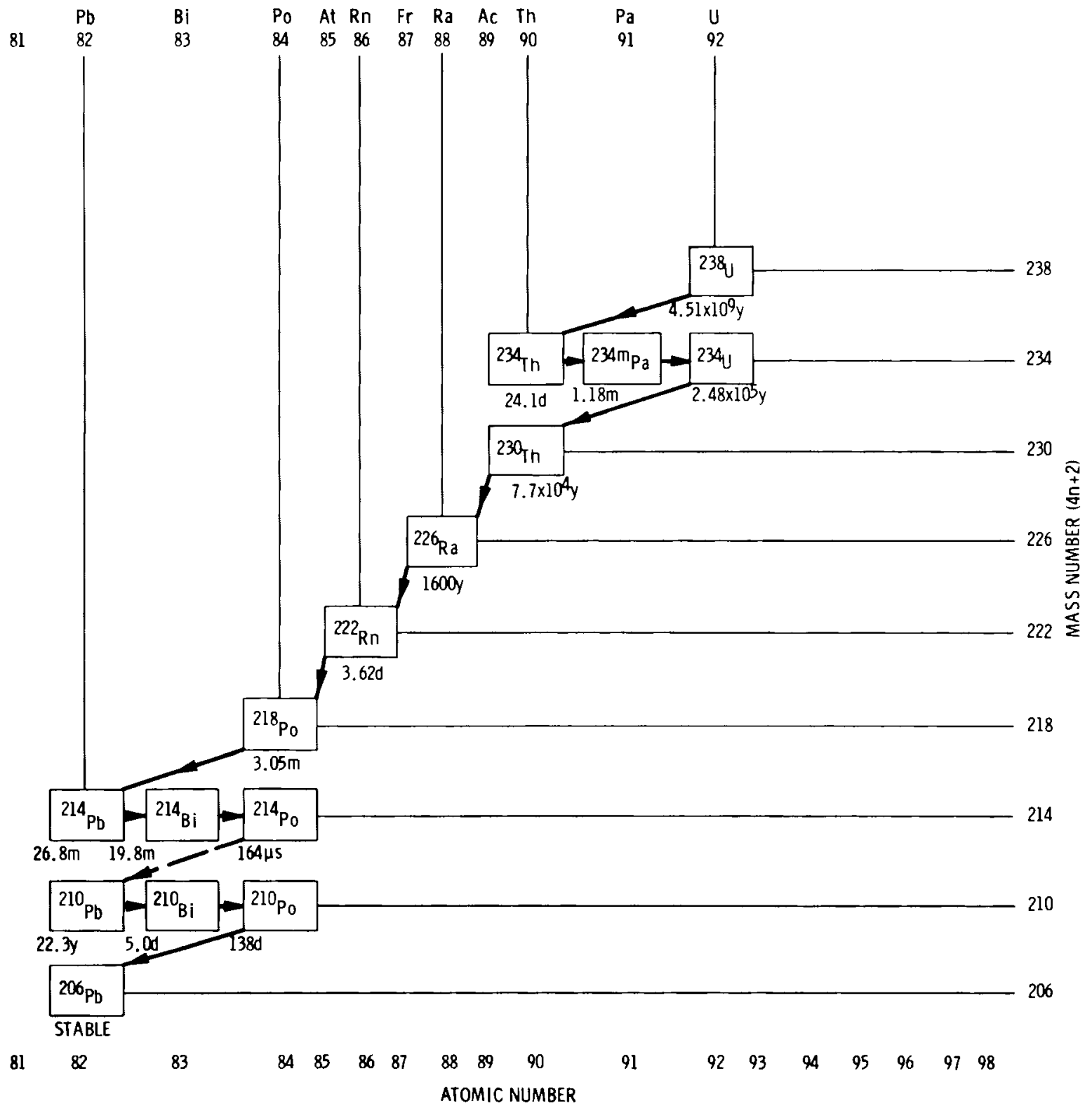

THE SOLID BOXES DENOTE NATURALLY OCCURRING NUCLIDES. AD JACENT NUMBERS INDICATE HALF -LIFE OF ISOTOPE. DIAGONAL ARROWS INDICATE a AND HORIZONTAL ARROWS $B$ DECAY. CHAIN BRANCHES OF < 1\% OMITED.

FIGURE A.2. Uranium-238 Decay Chain Series 


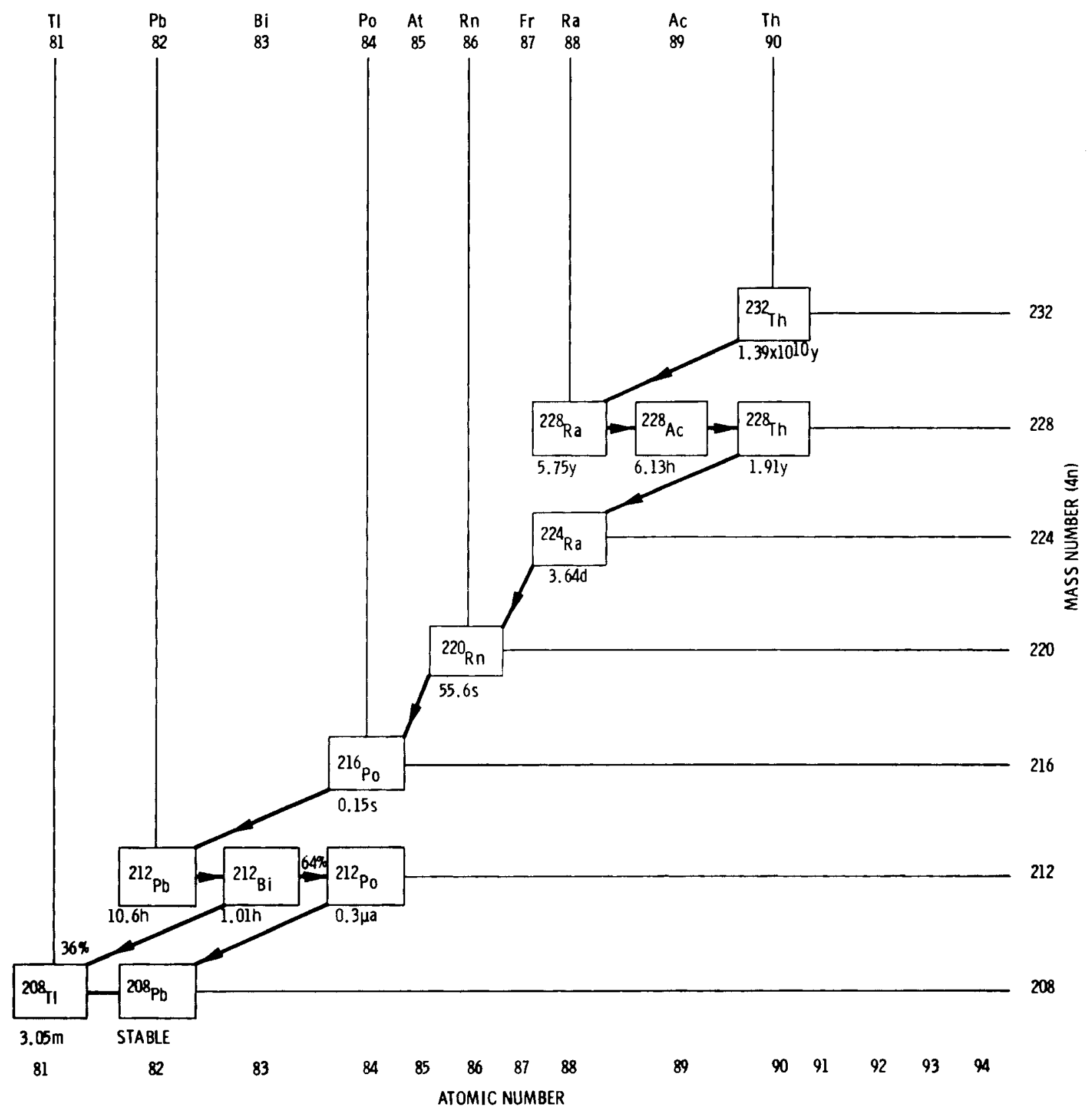

THE SOLID BOXES DENOTE NATURALLY OCCURRING NUCLIDES. ADJACENT NUMBERS INDICATE HALF LIFE OF ISOTOPE. DIAGONAL ARROWS INDICATE O AND HORIZONTAL ARROWS B DECAY.

FIGURE A.3. Thorium-232 Decay Chain Series 
TABLE A.5. Uranium and Thorium Content of Various Rock Classes

\begin{tabular}{|c|c|c|c|c|c|c|c|}
\hline & & & $U(p p m)$ & & & Th (ppm) & \\
\hline Rock Class & Rock Types & Mean & Range & $\underline{n^{(a)}}$ & Mean & Range & $\underline{n}^{(a)}$ \\
\hline Acid Extrusives & $\begin{array}{l}\text { rhyolite (obsidian \& tuffs), } \\
\text { latite, qtz dacite }\end{array}$ & 4.1 & $0.8-16.4$ & 13 & 11.9 & $1.1-41.0$ & 13 \\
\hline Acid Intrusives & $\begin{array}{l}\text { aplite, pegmatite, granite, } \\
\text { qtz monzonite }\end{array}$ & 4.5 & $0.1-30.0$ & 489 & 25.7 & $0.1-253.1$ & 493 \\
\hline $\begin{array}{l}\text { Intermediate } \\
\text { Extrusives }\end{array}$ & dacite, andesite & 1.1 & $0.2-2.6$ & 21 & 2.4 & $0.4-6.4$ & 21 \\
\hline $\begin{array}{l}\text { Intermediate } \\
\text { Intrusives }\end{array}$ & $\begin{array}{l}\text { qtz diorite (tonalite), } \\
\text { diorite, granodiorite }\end{array}$ & 3.2 & $0.1-23.4$ & 271 & 12.2 & $0.4-106.0$ & 273 \\
\hline Basic Extrusives & $\begin{array}{l}\text { basalts, olivine basalt, } \\
\text { tachylite, basaltic glass }\end{array}$ & 0.8 & $0.03-3.3$ & 55 & 2.2 & $0.05-8.8$ & 55 \\
\hline Basic Intrusives & $\begin{array}{l}\text { gabbro, diabase, olivine } \\
\text { gabbro, olivine diabase }\end{array}$ & 0.8 & $0.01-5.7$ & 119 & 2.3 & $0.03-15.0$ & 110 \\
\hline Ultrabasic & $\begin{array}{l}\text { peridotite, pyroxenite, } \\
\text { dunite, serpentinite }\end{array}$ & 0.3 & $0-1.6$ & 31 & 1.4 & $0-7.5$ & 30 \\
\hline $\begin{array}{c}\text { Alkali Feldspath- } \\
\text { oidal Intermed- } \\
\text { iate Extrusives }\end{array}$ & $\begin{array}{l}\text { Keratophyre, trachyte, } \\
\text { trachyandesite, phondite }\end{array}$ & 29.7 & $1.9-62.0$ & 138 & 133.9 & $9.5-265.0$ & 139 \\
\hline $\begin{array}{c}\text { Alkali Feldspath- } \\
\text { oidal Intermed- } \\
\text { iate Intrusives }\end{array}$ & $\begin{array}{l}\text { Syenite, syenodiorite, } \\
\text { monzonite, alkali syenite }\end{array}$ & 55.8 & $0.3-720.0$ & 75 & 132.6 & $0.4-880.0$ & 75 \\
\hline
\end{tabular}


TABLE A.5. (Contd)

\begin{tabular}{|c|c|c|c|c|c|c|c|}
\hline & & & $U(\mathrm{ppm})$ & & & Th (ppm) & \\
\hline Rock Class & Rock Types & Mean & Range & $n^{(a)}$ & Mean & Range & $\underline{n}^{(a)}$ \\
\hline $\begin{aligned} \text { Alkali Feldspath- } \\
\text { oidal Extrusives }\end{aligned}$ & $\begin{array}{l}\text { nepheline phonolite, leucite } \\
\text { phonolite, nepheline basalt } \\
\text { Leucite basalt, malilite } \\
\text { basalt nephline tephrite, } \\
\text { nepheline basanite }\end{array}$ & 2.4 & $0.5-12.0$ & 20 & 8.2 & $2.1-60.0$ & 20 \\
\hline $\begin{array}{l}\text { Alkali Feldspath- } \\
\text { oidal Basic } \\
\text { Intrusives }\end{array}$ & $\begin{array}{l}\text { alkali gabbros incl teschenite, } \\
\text { theralite, essexite, picrite, } \\
\text { shonlanite, kentellerite, } \\
\text { alkali theralite, ijolite }\end{array}$ & 2.3 & $0.4-5.4$ & 8 & 8.4 & $2.8-19.6$ & 8 \\
\hline $\begin{array}{l}\text { Chemical Sedi- } \\
\text { mentary Rocks }\end{array}$ & $\begin{array}{l}\text { limestone, dolomite, cherts, } \\
\text { evaporites }\end{array}$ & 3.6 & $0.03-26.7$ & 243 & 14.9 & $0.03-132.0$ & 239 \\
\hline Carbonates & carbonates & 2.0 & $0.03-18.0$ & 141 & 1.3 & $0.03-10.8$ & 131 \\
\hline $\begin{array}{l}\text { Detrital Sedi- } \\
\text { mentary Rocks }\end{array}$ & sandstone, shale, breccia & 4.8 & $0.1-80.0$ & 412 & 12.4 & $0.2-362.0$ & 411 \\
\hline $\begin{array}{l}\text { Metamor phosed } \\
\text { Igneous Rocks }\end{array}$ & $\begin{array}{l}\text { orthohornfels, orthogneiss, } \\
\text { amphibolite }\end{array}$ & 4.0 & $0.1-148.5$ & 128 & 14.8 & $0.1-104.2$ & 128 \\
\hline $\begin{array}{l}\text { Metamor phosed } \\
\text { Sedimentary } \\
\text { Rocks }\end{array}$ & $\begin{array}{l}\text { parahornfels, quartzite, } \\
\text { marble }\end{array}$ & 3.0 & $0.1-53.4$ & 207 & 12.0 & $0.1-91.4$ & 208 \\
\hline
\end{tabular}

(a) $n=$ number of analyses. 
TABLE A.6. Volume and Uranium Content of Volcanic Rocks

Remaining in Colorado's San Juan Mountains

\begin{tabular}{|c|c|c|c|}
\hline Formation or series & $\begin{array}{c}\text { Volume, } \\
\text { mi }^{3} \\
\end{array}$ & $\begin{array}{l}\text { U Content, } \\
\text { ppm }\end{array}$ & $\begin{array}{l}\text { Amount of } U \text {, } \\
\text { tons } \times 10^{6}\end{array}$ \\
\hline Pre-Potosi (east of Conejos) & 20 & 3.3 & 0.7 \\
\hline Lake Fork quartz latite & 40 & 3.0 & 1.3 \\
\hline San Juan tuff & 250 & 4.3 & 12 \\
\hline Silverton & 100 & 5.5 & 6.1 \\
\hline Conejos & 2000 & 2.2 & 48 \\
\hline Treasure Mountain rhyolite & 300 & 2.9 & 9.6 \\
\hline Sheep Mountain quartz latite & 80 & 2.5 & 2.2 \\
\hline Alboroto rhyolite & 600 & 4.0 & 26 \\
\hline Huerto quartz latite & 90 & 2.4 & 2.4 \\
\hline Piedra rhyolite & 250 & 4.0 & 11 \\
\hline Fisher quartz latite & 100 & 3.7 & 4.1 \\
\hline Hinsdale & 150 & 1.3 & 2.2 \\
\hline Approximate volume & 4000 & - & - \\
\hline Weighted average- & - & 2.9 & - \\
\hline Total uranium content & - & -- & 126 \\
\hline
\end{tabular}


TABLE A.7. Acid Intrusive Source Rocks for Uranium and Thorium

\begin{tabular}{|c|c|c|c|}
\hline Source Rocks & Location & $\begin{array}{l}\text { Uran ium, } \\
\text { ppm }\end{array}$ & $\begin{array}{l}\text { Thor ium, } \\
\text { ppm }\end{array}$ \\
\hline Conway Granite & New Hampshire & $12-16$ & 56 \\
\hline Westerly Granite & Rhode Island & & \\
\hline Granites & Maine & 6.0 & \\
\hline Front Range Granites & Colorado & 5.0 & \\
\hline Boulder Creek Batholith & Colorado & 2.2 & 13.4 \\
\hline Front Range Laramide Stocks & Colorado & 7.6 & \\
\hline Mount Evans Batholith & Colorado & 4.4 & 13.4 \\
\hline Monarch Batholith & Colorado & 2.2 & 13.4 \\
\hline Silver Plume Batholith & Colorado & 3.1 & 79.1 \\
\hline Indian Creek Batholith & Colorado & 4.9 & 62.7 \\
\hline Longs Peak Batholith & Colorado & 5.8 & 29.0 \\
\hline Kenosha Batholith & Colorado & 5.4 & 42.5 \\
\hline Log Cabin Batholith & Colorado & 6.7 & 24.5 \\
\hline Cripple Creek Batholith & Colorado & 3.2 & 24.0 \\
\hline Sherman Batholith & Colorado & 5.7 & 24.0 \\
\hline Pikes Peak Batholith & Colorado & 4.9 & 25.7 \\
\hline Wind River Uplift & Wyoming & 3.1 & 13.7 \\
\hline Bear Tooth Uplift & Montana & 1.6 & 16.8 \\
\hline Bighorn Uplift & Wyoming & 1.4 & 17.9 \\
\hline Granite Mountains & Wyoming & $2-5$ & -- \\
\hline Enchanted Rock Batholith (Granite) & Texas & 3.5 & -- \\
\hline Idaho Batholith (Granite) & Idaho & 2.5 & - \\
\hline Boulder Batholith (Granite) & Montana & 2.5 & -- \\
\hline Southern California Batholith (Granite) & California & 2.4 & -- \\
\hline Sierra Nevada Batholith (Granite) & Cal ifornia & 5.4 & -- \\
\hline
\end{tabular}





\section{ACKNOWLEDGMENTS}

The authors appreciate the helpful contributions of D. K. Davis, C. M. Devary, K. L. Feuerbacher, P. J. Liddel, and M. K. Sheeley. 



\section{DISTRIBUTION}

No. of

Copies

OFFSITE

A. A. Churm

DOE Chicago Patent Division 9800 South Cass Avenue

Argonne, IL 60439

Allied Chemical Corporation

(File Copy)

550 2nd Street

Idaho Falls, ID 83401

J. S. Allender

E. I. duPont de Nemours Co. Savannah River Laboratory

Aiken, SC 29081

Frank Arsenault, Director

Fuel Cycle and Environmental Research

USNRC

Washington, DC 20555

Assistant Director for

Radioactive Waste Management Branch

NRC Division of Materials and

Fuel Cycle Facility Licensing

Washington, DC 20545

Dr. Greg Baecher

Department of Civil Engineering

MIT

77 Massachussetts Avenue

Cambridge, MA 02139

R. G. Barnes

General Electric Company

175 Curtner Avenue (M/C 858)

San Jose, CA 95125
No. of

Copies

Battelle Memorial Institute

Office of Nuclear Waste Isolation

Attn: Beverly Rawles

$505 \mathrm{King}$ Avenue

Columbus, $\mathrm{OH} 43201$

R. A. Beall

U. S. Department of Interior Bureau of Mines

Albany Research Center

1450 W. Queen Avenue

Albany, OR 97321

Gary W. Bea 11

Oak Ridge National Laboratory P.0. Box $X$

Oak Ridge, TN 37830

W. G. Belter

DOE Division of Biomedical and Environmental Research

Earth Sciences Branch

Washington, DC 20545

M. Benedict

Massachusetts Institute of Technology

Cambridge, MA 02139

Gary L. Benson

Battelle

N. 9508 Div. St., Suite E

Spokane, WA 99218

Larry Benson

Lawrence Berkeley Laboratories

1 Cyclotron Road

Bldg 70A/1160

Berkeley, CA 94720 
No. of

Copies

Dr. Felton Bingham

Division 4514

Sandia Laboratories

Albuquerque, NM 87115

J. 0. Blomeke

Union Carbide Corporation (ORNL)

Chemical Technology Division

P.0. Box $Y$

Oak Ridge, TN 37830

A. Brandstetter

Office of Nuclear Waste

Isolation

Battelle Memorial Institute

505 King Ave.

Columbus, $\mathrm{OH} 43201$

Chaim Braun

Brookhaven National Laboratory

Energy Systems Library

Building 902

Upton, NY 11973

J. D. Bredehoeft

U.S. Geological Survey

Water Resources Division

Reston, VA 22092

H. Brugger

Office of Nuclear Waste

Isolation

Battelle Memorial Institute

505 King Ave.

Columbus, $\mathrm{OH} 43201$

W. A. Brobst

DOE Division of Environmental

Control Technology

Washington, DC 20545

L. H. Brooks

Gulf Energy and Environmental Systems

P.0. Box 81608

San Diego, CA 92138
No. of

Copies

R. A. Buckham

Allied-General Nuclear Service P.0. Box 847

Barnwe11, SC 29812

R. L. Bullard

Chief, Environmental Specialist Branch

Nuclear Regulatory Commission

Directorate of Regulation

7920 Norfolk Avenue

Bethesda, MD 20014

3 H. C. Burkholder

Office of Nuclear Waste Isolation

Battelle Memorial Institute

505 King Ave.

Columbus, $\mathrm{OH} 43201$

Jim Channell

State of New Mexico

Environmental Evaluation Group

P.0. Box 968

Santa Fe, NM 87503

T. C. Chee

DOE Office of Nuclear Waste Management

Washington, DC 20545

Dr. Ping Chen

ONWI

505 King Avenue

Columbus, $\mathrm{OH} 43201$

R. B. Chitwood

DOE Division of Nuclear Power Development

Washington, DC 20545

H. C. Claiborne

Union Carbide Corporation (ORNL)

Chemical Technology Division

P.0. Box X, Bldg. 3017

Oak Ridge, TN 37830 
No. of

Copies

Jess Cleveland

U.S. Geological Survey

Denver Federal Center

Mail Stop 412

P.0. Box 25046

Lakewood, C0 80225

J. G. Cline, General Manager

NYS Energy Research and

Development Authority

Agency B1dg. \#2

Empire State Plazza

Albany, NY 12223

Combustion Division

Combustion Engineering, Inc.

Windsor, CT 06095

Professor Jay Conover

Dept. of Statistics

Systems \& Quatitative Sciences

Texas Tech. University

Lubbock, TX 79401

Dr. Bob Cranwell

Division 4413

Sandia Laboratories

Albuquerque, NM 87115

Dr. Mike Cullingford

USNRC

Mail Stop 3103

Washington, DC 20555

R. E. Cunningham

Deputy Director for Fuels and Materials

Nuclear Regulatory Commission

Silver Springs, MD 20910

C. R. Cooley

DOE Office of Nuclear Waste

Management

Washington, DC 20545
No. of

Copies

R. L. Cooley

U.S. Geological Survey

Building 53

Federal Center

Denver, CO 80225

Howard A. Coombs

Department of Geological

Sciences

University of Washington

Seattle, WA 98194

J. Crosby, Geologist

Washington State Water Research Center

Pullman, WA 99163

George A. Cowan

Los Alamos Scientific Laboratory

P.0. Box 1663

Los Alamos, NM 87545

Jared Davis

U.S. Nuclear Regulatory Committee

Washington, DC 20555

G. Debuchananne, Director

U.S. Geological Survey

2100 M. Street

Washington, DC 20037

Tom Doe

Bldg. 90, Room 1070

Lawrence Berkeley Labs

University of California

Berkeley, CA 94720

27 DOE Technical Information Center

F. S. Dombek

General Atomic Company

P.0. Box 81608

San Diego, CA 92138 
No. of

Copies

Dr. Fred Donath

2021 S. Cureton Drive

Urbanna, IL' 61801

Terry Donich

Lawrence Livermore Laboratory

P.0. Box 808

Livermore, CA 94550

Robert G. Dosch

Sandia Laboratories

P.0. Box 5800

A1buquerque, NM 87115

J. P. Duckworth

Plant Manager

Nuclear Fuel Services, Inc.

P.0. Box 124

West Valley, NY 14171

Bruce R. Erdal

Los Alamos Scientific

Laboratory

CNC-11, MS-514

Los Alamos, NM 87545

Chet W. Francis

Oak Ridge National Laboratory

P.0. Box X, Bldg 2001

0ak Ridge, TN 37830

J. D. Freeman

NUS Corporation

4 Research Place

Rockville, MD 20850

James Feinstein

NUS

4 Research P1ace

Rockville, MD 20805

Dan Feringer

USNRC

Washington, DC 20555
No. of

Copies

Dr. Dan Fortney

Division 4512

Sandia Labs

Albuquerque, NM 87115

Craig Frederickson

West inghouse

Albuquerque, NM 87115

Sherman Fried

Argonne National Laboratory

9700 South Cass Avenue

Argonne, IL 60439

Arnold Friedman

Argonne National Laboratory

9700 South Cass Avenue

Argonne, IL 60439

Steven J. Fritz

E. I. duPont de Nemours Co.

Savannah River Laboratory

Aiken, SC 29081

W. Gami 11

Chief, Site Analysis Branch

Nuclear Regulatory Commission

Directorate of Regulation

7920 Norfolk Avenue

Bethesda, MD 20014

Mike Giuffre

Analytic Sciences Corp.

6 Jacob Way

Redding, MA 01867

Paul Gnirk

$\mathrm{Re} / \mathrm{Spec}$ Inc.

Rapid City, SD 57701

E. S. Goldberg

DOE Savannah River Operations Office

P.0. Box A

Aiken, SC 29801 
No. of

Copies

H. W. Godbee

Union Carbide Corporation (ORNL)

Chemical Technology Division

P.0. Box $Y$

Oak Ridge, TN 37830

Dr. Charles Hadlock

Arthur D. Little, Inc.

25 Acorn Park

Cambridge, MA 02140

John Handin

Center for Tectonophysics

Texas A \& M University

College Station, TX 77840

Frankie Hayes

INTERA Environmental Consultants, Inc.

11999 Katy Freeway, Suite 610

Houston, TX 77079

C. A. Heath

DOE Office of Nuclear Waste

Management

Washington, DC 20545

Philip Helmke

Department of Soil Science

1525 Observatory Drive

University of Wisconsin

Madison, WI 53706

H. Henning

Electric Power Research Institute

3412 Hillview Avenue

P.0. Box 10412

Palo Alto, CA 94301

N. Hubbard

Office of Nuclear Waste

Isolation

Battelle Memorial Institute

505 King Ave.

Columbus, $\mathrm{OH} 43201$
No. of

Copies

Dr. Thomas Hunter

Division 4512

Sandia Labs

Albuquerque, NM 87115

Peter Huyakorn

Dames \& Moore

44 Mall Road

Burlington, MA 01803

Ron Inman

Division 1223

Sandia Labs

Albuquerque, NM 87115

Dr. Dana I sherwood

Lawrence Livermore Labs

P.0. Box 808

Livermore, CA 94550

Professor Brann Johnson

Department of Geology

Texas A\&M University

College Station, TX 77844

Lamar J. Johnson

Environmental Studies

Health Research Division

Los Alamos Scientific Lab.

Los Alamos, NM 87545

R. F. Kaufman

Converse Ward

Davis Dixon

4055 Spencer, Suite 120

Las Vegas, NV 89109

J. W. Keely

Chief, Subsurface Environmental

Research Branch

Robert S. Kerr Research Lab

P.0. 1198

Ada, OK 74820 
No. of

Copies

Charles Killpack

Holcomb Research Institute

Butler University

Indianapolis, IN 46208

J. Kircher

Office of Nuclear Waste Isolation

Battelle Memorial Institute

505 King Ave.

Columbus, $\mathrm{OH} 43201$

L. T. Klein

NUS Corporation

14011 Ventura Boulevard

Suite 306

Sherman Oaks, CA 91423

Dan Kleitman

Department of Mathematics

MIT

77 Massachusetts Avenue

Cambridge, MA 02139

David Kocher

Oak Ridge National Labs

Building 7509

P.0. Box $X$

Oak Ridge, TN 37838

George K. Kukla

Lamont-Doherty Geological

Observatory

Palisades, NY 10964

Steve Lambert

Sandia Laboratories

P.0. Box 5800

Albuquerque, NM 87115

Harry Landon

Nuclear Regulatory Commission

Research Division

Washington, DC 20555
No. of

Copies

R. E. Landreth

Environmental Protection Agency

5555 Ridge Ave.

Cincinnati, $\mathrm{OH} 45213$

R. B. Lantz

Executive Vice-President

INTERA Environmental Consultants

11511 Katy Freeway, Suite 610

Houstohn, TX 77079

T. Lash

Natural Resources Defense

Counci1, Inc.

664 Hamilton Avenue

Palo Alto, CA 94301

D. H. Lester

Science Applications, Inc.

1200 Prospect Street

P.0. Box 2351

La Jolla, CA 92038

M. Levenson

Electric Power Research

Institute

3412 Hillview Ave.

P.0. Box 10412

Palo Alto, CA 94304

Paul W. Levy

Brookhaven National Laboratory

Upton, NY 11973

Dr. Regina Link

Sandia Laboratories

Albuquerque, NM 87115

Marshall Little

State of New Mexico Environ-

mental Evaluation Group

P.0. Box 968

Santa Fe, NM 87503 
S. E. Logan

Los Alamos Technical Associates, Inc.

P.0. Box 410

Los Alamos, NM 87544

Robert D. MacNish

USGS, WRD

301 W. Congress Street

Tuscon, AZ 85701

W. C. McClain

Oak Ridge National Laboratory

P.0. Box $X$

Oak Ridge, TN 37830

G. J. McCarthy

Dept. of Chemistry

North Dakota State University

Fargo, ND 56102

Dr. Thomas Maddock

Departnent of Hydrology

\& Water Resources

University of Arizona

Tuc son, AZ 85721

Wende 11 Marine

E. I. duPone de Nemours

Savannah River Labs

Aiken, SC 29808

M. D. McCormack

E.G. \& G. Idaho, Inc.

P.0. Box 1625

Idaho Falls, ID 83401

David Meiri

NUS Corp.

4 Research Pl.

Rockville, MD 20805

G. L. Meyer

Environmental Protection Agency

Technology Assessment Div.

(AW-559)

Office of Radiation Programs

Washington, DC 20460
Sheldon Meyers

DOE Office of Nuclear Waste

Management

Washington, DC 20545

Mary Michaux

INTERA Environmental Consultants, Inc.

11999 Katy Freeway, Suite 610

Houston, TX 77079

Marise Mikulis

Authur D. Little, Inc.

25 Acorn Park

Cambridge, MA 02140

M. Molecke

Sandia Laboratories

P.0. Box 5800

Albuquerque, NM 87115

W. E. Mott

DOE Division of Environmental Control Technology

Washington, DC 20545

Anthony Mucciardi

Adaptronics, Inc.

Westgate Research Park

7700 01d Springhouse Road

McLean, VA 22101

Barry Naft

NUS

4 Research Place

Rockville, MD 20805

Dr. T. N. Narsimhan

Lawrence Berkeley Labs

University of California

Berkeley, CA 94720

J. Neff, Program Manager

Department of Energy

Columbus Program Office

505 King Avenue

Columbus, $\mathrm{OH} 43201$ 
No. of

Copies

I vars Neretnieks

Earth Science Division

Lawrence Berkeley Laboratory

University of California

Berkeley, CA 94720

Nei 1 Norman

Bechtel, Inc.

P.0. Box 3965

San Francisco, CA 94105

E. D. North, Director of

Technical Administration

Nuclear Fuel Services, Inc.

6000 Executive Blvd., Suite 600

Rockville, MD 20852

E. J. Nowak

Sandia Labs

Albuquerque, NM 87115

Oak Ridge National Laboratory (DOE)

Central Research Library

Document Reference Section

P.0. Box $X$

Oak Ridge, TN 37830

E. M. Oblow

Oak Ridge National Labs

P.0. Box $X$

Oak Ridge, TN 37830

G. Oertel

DOE Office of Nuclear Waste Management

Washington, DC 20545

Dr. Nestor R. Ortiz

Division 4413

Sandia Laboratories

Albuquerque, NM 87115

Dr. Suresh Pahwa

INTERA Environmental

Consultants, Inc.

11511 Katy Freeway, Suite 610

Houston, TX 77079
No. of

Copies

Dr. Bill Pariseau

315 W B B

University of Utah

Salt Lake City, UT 84112

Dr. Frank Parker

Dept. of Environmental

Engineering

Vanderbilt University

Nashville, TN 37235

Dr. Bartlett Paulding, Jr.

Geotechnical Engineers

1017 Main Street

Winchester, MA 01890

Dr. Joe Pearson

INTERA Environmental Consu 1tants, Inc.

11999 Katy Freeway, Suite 610 Houston, TX 77079

A. F. Perge

DOE Office of Nuclear Waste

Management

Washington, DC 20545

T. H. Pigford

Dept. of Nuclear Engineering

Univ. of California

Berkeley, CA 94720

G. F. Pinder

Princeton University

Department of Civil and Geological Engineering

Princeton, NJ 08540

M. S. Plodinec

E. I. duPont DeNemours and Company

Savannah River Laboratory

Aiken, SC 29801

Greg Pollak

Lawrence Livermore Labs

P.0. Box 808

Livermore, CA 94550 
No. of

Copies

R. G. Post

College of Engineering

University of Airzona

Tucson, AZ 85721

G. E. Raines

ONWI

505 King Avenue

Columbus, $\mathrm{OH} 43201$

Dr. Mark Reeves

INTERA Environmental Consultants, Inc.

11999 Katy Freeway, Suite 610

Houston, TX 77079

\author{
J. J. Reilly \\ Brookhaven National Laboratory \\ Research Library \\ Reference Section \\ Information Division \\ Upton, Long Is land, NY 11973
}

Ausra Richards

NUS Corporation

4 Research Place

Rockville, MD 20805

Paul Rickert

Argonne National Laboratory

9700 South Cass Avenue

Argonne, IL 60439

Larry Rickertson

Science Applications, Inc.

Oak Ridge, TN 37830

A. P. Roeh, Manager

Allied Chemical Corporation

550 2nd Street

Idaho Fa11s, ID 83401

R. G. Romatowski

DOE Office of Nuclear Waste Management

Washington, DC 20545
No. of

Copies

Yigal Ronen

Oak Ridge National Laboratory

P.0. Box $X$

Oak Ridge, TN 37838

D. Rose

Massachusetts Institute of Techno logy

Cambridge, MA 02139

B. Ross

TASC

6 Jacob Way

Reading, MA 01867

Dr. James Russel1

Petroleum Engineering

\& Physics Department

Texas A\&M University

College Station, TX 77844

Dr. Genevieve Segol

Bechtel, Inc.

P.0. Box 3965

San Francisco, CA 94105

M. J. Shaffer

U.S. Department of the Interior Bureau of Reclamation

Engineering and Research Center

Federal Center

Denver, C0 80225

Dr. Normal Shutler

Deane, Snowden, Shutler, Garrish \& Gherardi

1607 New Hampshire Ave., NW

Washington, DC 20009

Raymond Siever

Department of Geological

Sciences

Harvard University

Cambridge, MA 02138 
No. of

Copies

E. S. Simpson, Professor Department Hydrology and Water Resources

University of Arizona

Tucson, AZ 85721

Terry Steinborn

International Engineering $\mathrm{Co}$.

180 Howard Street

San Francisco, CA 94105

M. M. Steindler/L. E. Trevorrow Argonne National Laboratory

9700 South Cass Avenue

Argonne, IL 60439

D. B. Stewart

U. S. Department of Interior

959 National Center

Geological Survey

Reston, VA 22092

Martin Stone

EG\&G

SSB

P.0. Box 1625

Idaho Falls, ID 83401

Bill Sutcliffe

Lawrence Livermore Laboratories P.0. Box 808

Livermore, CA 94550

John Suich

Environmental Transport Division

Savannah River Laboratory

Aiken, SC 29801

Victor Swan

Washington State University

Geology Department

Pullman, WA 99163

Dr. Ed Tang

INTERA Environmental

Consultants, Inc.

11999 Katy Freeway, Suite 610

Houston, TX 77079
No. of

Copies

Technical Secretary

National Academy of Science

Committee on Radioactive Waste Management

National Research Council

2101 Constitution Avenue

Washington, DC 20418

B. R. Teer

Transnuclear, Inc.

One North Broadway

White Plains, NY 10601

Nicholas P. Timof eeff

Contamination Control Program

Rocky Mountain Arsenal

Denver, CO 80225

Steve Topp

E. I. duPont deNemours Co.

Savannah River Laboratory

Aiken, SC 29801

John Waddell

ONWI

505 King Avenue

Columbus, $\mathrm{OH} 43201$

E. Wallace

Supervisor, Water Resources Division

State of Washington

Department of Ecology

Olympia, WA 98501

R. D. Walton

DOE Office of Nuclear Waste

Management

Washington, DC 20545

J. S. Y Wang

Lawrence Berkeley Lab

Univ. of California

Berkeley, CA 94720 
No. of

Copies

W. Weart

Division 1140

Sandia Laboratories

Albuquerque, NM 87107

M. Wheeler

Division $\mathrm{H} 8$

Environmental Studies

LoS Alamos Scientific Laboratory

Los Alamos, NM 87545

J. B. Whitsett

DOE Idaho Operations Office

550 2nd Street

Idaho Falls, ID 83401

Lawrence Wight

TERA

2118 Milvia Street

Berkeley, CA 94704

Dr. Bob Wilems

INTERA Environmental Consultants, Inc.

11999 Katy Freeway, Suite 610

Houston, TX 77079

P. A. Witherspoon

Department of Civil Engineering

University of California

Berkeley, CA 94720

John Van Cleve

DOE Oak Ridge Operations Office

P.0. Box $X$

Oak Ridge, TN 37830

D. L. Vieth

DOE Office of Nuclear Waste

Management

Washington, DC 20545

Dr. Sydney Yakowitz

Systems \& Industrial Engineering

University of Arizona

Tucson, AZ 85721
No. of

Copies

V. Yuan

Natural Resources Defense

Council, Inc.

664 Hamilton Avenue

Palo Alto, CA 94301

D. L. Ziegler

Dow Chemical Company (DOE)

Rocky Flats Division

P.0. Box 888

Golden, C0 80401

E. Zebroski

Electric Power Research Institute

3412 Hillview Ave.

P.0. Box 10412

Palo Alto, CA 94304

\section{ONSITE}

4 DOE Richland 0perations Office

P. A. Craig

H. E. Ransom

J. J. Schreiber

M. W. Shupe

6 Rockwell Hanford Operation's

R. A. Deju

J. D. Kaser

M. J. Kupfer

W. W. Schultz

D. D. Wodrich

B. J. Wood

File copy

2 Exxon Nuclear Company

S. J. Beard

G. Jansen 
No. of

Copies

Joint Center for Graduate Study

J. Cooper

2 United Nuclear Industries, Inc.

T. E. Dabrowski

A. E. Engler

Westinghouse Hanf ord Company
A. G. Blasewitz

Pacific Northwest Laboratory

R. L. Aaberg

E. M. Arnold

D. A. Baker

W. F. Bonner

D. J. Bradley

J. B. Brown, Jr.

D. B. Cearlock

L. A. Chick

T. D. Chikalla

M. 0. Cloninger (85)

C. R. Cole

W. V. DeMier

C. M. Devary (3)

P. G. Doctor

D. W. Dragnich

E. A. Eschbach

J. W. Finnigan
No. of

Copies

M. Foley

H. T. Fullam

A. J. Haverfield

J. H. Jarrett

Y. B. Katayama

W. L. Kuhn

D. E. Larson

P. J. Liddell

R. C. Liikala

J. L. McElroy

J. E. Mendel

B. A. Napier

R. W. Nelson

R. E. Night ingale

D. E. Olesen

G. M. Petrie

A. M. Platt

W. A. Ross

R. J. Serne

J. K. Soldat

J. L. Swans on

H. H. Van Tuyl

B. E. Vaughan

R. A. Walter

J. F. Washburn

E. C. Wats on

R. E. Westerman

0 . J. Wick (5)

R. D. Widrig (5)

R. E. Wildung

L. D. Williams

W. K. Winegardner

Technical Information (5)

Publishing Coordination (2) 